\title{
13. SILICOFLAGELLATE STRATIGRAPHY, DEEP SEA DRILLING PROJECT, LEG 36
}

\author{
Karen Eason Busen and Sherwood W. Wise, Jr., Antarctic Marine Geology Research Facility, \\ Department of Geology, Florida State University, Tallahassee, Florida
}

\begin{abstract}
DSDP Leg 36 recovered abundant and well-preserved silicoflagellates in Tertiary sediments of the Falkland Plateau and the adjacent Malvinas Outer Basin. Of particular interest are the older assemblages of Paleocene (Site 327), Eocene (Site 328), and Oligocene (Sites 328 and 329) age which were recovered at relatively shallow subbottom depths ( 30 to $70 \mathrm{~m}$ ) except at Site 329 where Oligocene silicoflagellates were recovered down to about 420 meters. Paleotemperature plots for a long Miocene section at Site 329 show a warming trend in the upper Miocene, consistent with previous Southern Ocean studies. Pliocene and Pleistocene paleotemperature curves could not be constructed due to the sparse flora in that interval. A new zone, the Mesocena circulus/Mesocena diodon Zone, is established for the middle to upper Miocene. The zone represents the co-occurrence of Mesocena circulus and Mesocena diodon, two species which have not been found together in other areas. Five new species and subspecies named and described are: Corbisema cuspis, Corbisema navicula constricta, Dictyocha fallacia, Distephanus crux fenestratus, and Pseudomicromarsupium gombosum.
\end{abstract}

\section{INTRODUCTION}

During Leg 36 of the Deep Sea Drilling Project, six drilling sites, DSDP 326-331, were cored adjacent to the Falkland Plateau north of Antarctica (Figure 1). Tertiary material recovered contains in discontinuous sections Paleocene through Recent silicoflagellates (Table 1). The flora is abundant, well preserved, and diverse in the Paleocene through Oligocene material and less so in the Miocene through Recent material. The more complete Paleocene through Oligocene sequences in particular are useful for comparison with other sections of similar age.

All zones discussed and described in this report are compared with biostratigraphic zones from other areas. In view of the large amount of new material which has accumulated in recent years, particularly with regard to systematics, a review of the previous work on silicoflagellates and taxonomy is also included.

\section{PREPARATION OF SAMPLES AND METHOD OF STUDY}

Raw samples were first washed with $20 \%$ hydrogen pyroxide and heated in $200-\mathrm{ml}$ beakers with hydrochloric acid to remove carbonate. The undissolved portions were then washed, centrifuged, and decanted five times in plastic test tubes. The first wash was with sodium pyrophosphate to remove the clays and the last four washes were with distilled water. Ten drops of suspended sample were then pipetted onto a cover slip, dried, and mounted in Hyrax.
Four slides were made for each sample. The preferred number of specimens counted for each sample was 300 (Kanaya, 1957; Donahue, 1970; Abbott, 1972). If all four slides were examined and less than 300 specimens had been counted, the total number of specimens counted was recorded. Sites studied in this manner were: Site 327 (Hole 327A), Site 328 (Holes $328,328 \mathrm{~A}$, and 328B), and Site 329 (Hole 329). All illustrations in Plates 1-12 are photomicrographs taken in bright-field illumination unless otherwise stated in the figure captions.

\section{HISTORICAL}

The first silicoflagellates were described in 1837 by Ehrenberg. These were fossil forms from Sicily, and he erected the genus Dictyocha to encompass them. In 1839 Ehrenberg discovered the first living silicoflagellates in Kiel Bay, and described six species, D. fibula, D. navicula, D. polyactis, D. speculum, D. ? stella, and $D$. triangula. It is to his credit that four of the six species he described are almost unchanged in definition from his original.

Ehrenberg considered the genus Dictyocha to belong, along with the diatoms, in a class of infusorians, the Polygastrica (Ehrenberg, 1839). Kutzing (1844) later considered them to be diatoms. Muller (1856) and Haeckel (1862) included them among the radiolarians. It was Borgert in 1890 who introduced the term silicoflagellate. He noticed the presence of a single flagellum in living Distephanus, which excluded them 


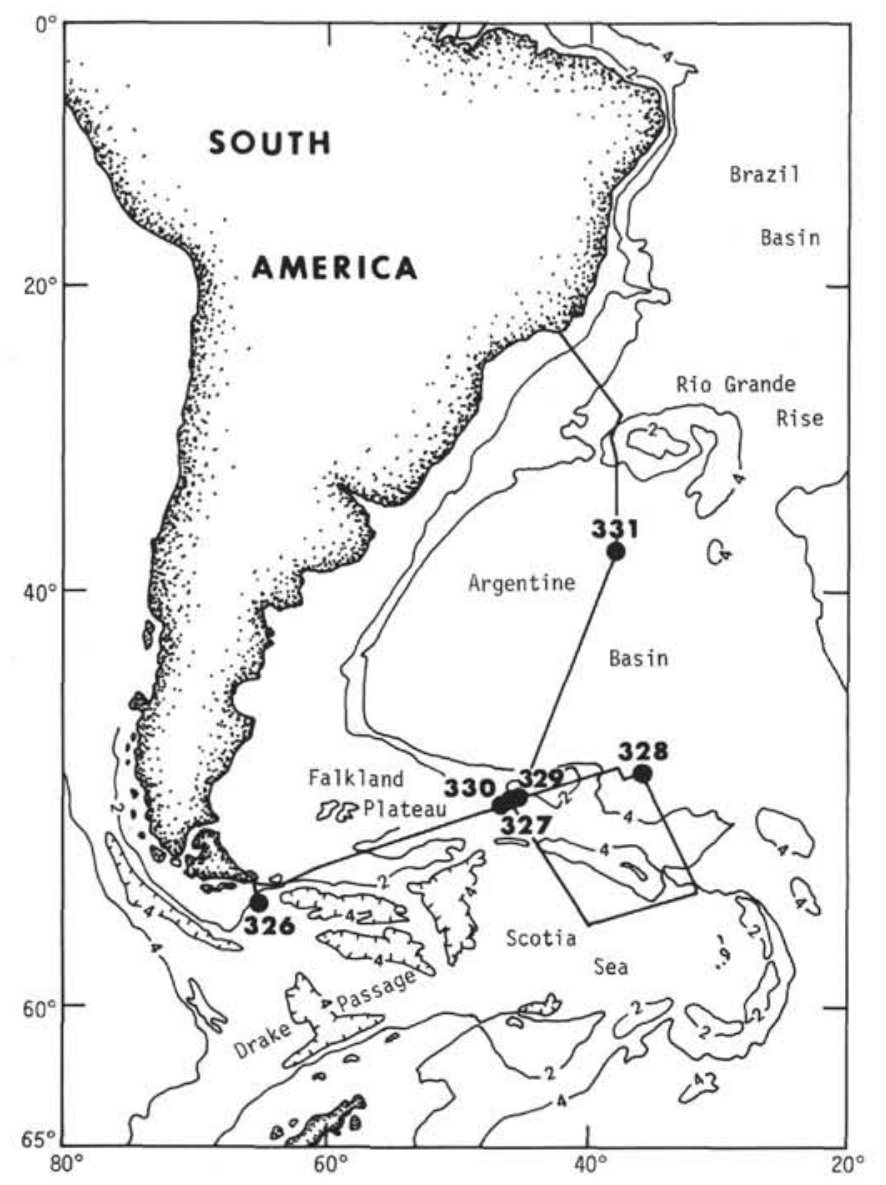

Figure 1. Location of Leg 36 drill sites.

from the radiolarians, and proposed the Order Silicoflagellata. Haeckel (1894) placed the silicoflagellates in the plant kingdon as the algal order Dictyochae under the Phytomastigia because of the presence of brownish-yellow chromatophores. Lemmermann (1901) proposed two orders to separate silicoflagellates from ebridians, with which they had previously been included. The Order Siphonotestales included uniflagellate forms with skeletons formed of hollow tubes (including the family Dictyochaeceae) and the Order Stereotestales included biflagellate forms with solid skeletons (including the family Ebriaceae).

The exact relationship of the silicoflagellates to the other algae is far from clearcut. They possess a siliceous endoskeleton, a single flagellum, brownish-yellow chromatophores, and reserve food substances of the leucosin type. They are now placed in their own Class, the Silicoflagellatophyceae, and in the Order Siphonotestales.

As mentioned above the first silicoflagellate genus described was the genus Dictyocha (Ehrenberg, 1837). In 1843 Ehrenberg described the second genus, Mesocena. He designated all forms with a skeleton shaped like a reticulate star as Dictyocha and all forms with a simple ring-shaped skeleton as Mesocena. In 1880 Stohr described the genus Distephanus. In 1887 Haeckel, on the basis of the structure of the apical apparatus, divided the genus Dictyocha Ehrenberg into three genera: Dictyocha Ehrenberg proper, Distephanus Stohr, and Cannopilus Haeckel.
In 1901 Lemmermann revised all the silicoflagellate species previously described by Ehrenberg and since reassigned to new genera by Haeckel. Lemmermann based his species definitions on the number of sides of the basal ring in differentiating the Dictyocha and Distephanus species and on the number of apical windows for differentiating the Cannopilus species. He also took into account the size of the basal ring and the presence or absence of radial horns. Schulz (1928) and Gemeinhardt (1930) subsequently used Lemmermann's scheme of classification.

The genera Corbisema Hanna, Cornua Schulz, and Vallacerta Hanna were all introduced in 1928. Outline of the basal ring was important in the classification of all three. It was not until 1940 that the genera Naviculopsis Frenguelli and Paradictyocha Frenguelli were introduced.

Frenguelli (1940) and Deflandre (1950a, b) made a definite departure from the old systematic principles for classification. Rather than emphasizing the general outline of the basal ring and the structure of the apical apparatus, which they considered far too variable, they concentrated on the less plastic morphological characteristics. Especially important to Frenguelli and Deflandre were the position of the supporting spines, the direction of the radial horns, the trend toward reduction of the apical apparatus, and the flattening, or lack thereof, of the basal rods. Frenguelli also considered size to be of great importance. Because of the great variation observed among the silicoflagellates, they felt that the outline of the basal ring could assume a variety of similar forms within different genera, and they considered the form of the basal ring to be an expression of the variation of the species. Therefore, Frenguelli and Deflandre attributed more importance to establishing the phylogenetic links between the various species and less to the overall morphological characteristics. Thus they were the first to attempt to decipher the phylogeny of the silicoflagellates.

The use of phylogeny for purposes of classification proved impractical, however, because of the lack of precise criteria for designating generic affiliation and because of the fluctuation in interpretation of supposed phylogenetic associations. Thus at present silicoflagellates are classified primarily on the basis of morphological characteristics and secondarily on the basis of phylogeny. Basal outline and the structure of the apical apparatus are once again considered as valid criteria for classification, but are considered to be of less importance than was originally assumed. Many of the morphological features proposed as definitive by Frenguelli and Deflandre, such as the position of the sustaining rods, are now considered to be of major significance in silicoflagellate classification.

Virtually all of the work on the silicoflagellates was taxonomical until the later half of the twentieth century. Many of the early descriptions give ages only as fossil or Recent and list only the name of the country where the samples were collected as the site reference. In 1928, however, Hanna wrote that he considered silicoflagellates to be excellent age indicators of marine sedimentary rocks because of the brief time span occupied by more of the species and because of their wide geographic distribution. But the first real 
TABLE 1

Biostratigraphic Summary of all Cores Studied From DSDP Leg 36

\begin{tabular}{|c|c|c|c|c|c|c|c|}
\hline \multirow[b]{2}{*}{ Age } & \multirow{2}{*}{\multicolumn{2}{|c|}{ Zone }} & \multicolumn{5}{|c|}{ Hole } \\
\hline & & & $327 \mathrm{~A}$ & 328 & $328 \mathrm{~A}$ & $328 \mathrm{~B}$ & 329 \\
\hline Quaternary & \multicolumn{2}{|c|}{$\begin{array}{l}\text { Distephanus } \\
\text { speculum A }\end{array}$} & \multirow{6}{*}{$\begin{array}{c}\text { Mixed } \\
1-3,146-147 \mathrm{~cm} \\
\text { to } \\
1-1,129-130 \mathrm{~cm}\end{array}$} & $\begin{array}{c}1-5,138-140 \mathrm{~cm} \\
\text { to } \\
1-1,1-3 \mathrm{~cm}\end{array}$ & $\begin{array}{c}2-1,31-32 \mathrm{~cm} \\
\text { to } \\
1-1,35-37 \mathrm{~cm}\end{array}$ & $\begin{array}{c}1-2,70-72 \mathrm{~cm} \\
\text { to } \\
1-1,130-132 \mathrm{~cm}\end{array}$ & \\
\hline \multirow{2}{*}{ Pliocene } & \multicolumn{2}{|c|}{$\begin{array}{l}\text { Distephanus } \\
\text { speculum B }\end{array}$} & & $\begin{array}{c}3-1,5-7 \mathrm{~cm} \\
\text { to } \\
2-1,148-150 \mathrm{~cm}\end{array}$ & & $\begin{array}{c}2-1,144-146 \mathrm{~cm} \\
\text { to } \\
1-3,5-7 \mathrm{~cm} \\
\end{array}$ & \\
\hline & & & & & & & \\
\hline \multirow{3}{*}{ Miocene } & \multicolumn{2}{|c|}{$\begin{array}{c}\text { Mesocena circulus/ } \\
\text { Mesocena diodon }\end{array}$} & & $\begin{array}{l}3-4,5-7 \mathrm{~cm} \text { to } \\
3-2,87-89 \mathrm{~cm}\end{array}$ & & & $\begin{array}{l}1-3,30-32 \mathrm{~cm} \text { to } \\
12-3,30-32 \mathrm{~cm}\end{array}$ \\
\hline & \multicolumn{2}{|c|}{ Mesocena circulus } & & & & & $\begin{array}{c}13-3 \text { to } \\
15-5,30-32 \mathrm{~cm}\end{array}$ \\
\hline & \multicolumn{2}{|c|}{$?$} & & & & & $\begin{array}{c}16-5,30-32 \mathrm{~cm} \\
\text { to } 19-4,30-32 \mathrm{~cm}\end{array}$ \\
\hline Oligocene & \multicolumn{2}{|c|}{$\begin{array}{l}\text { Naviculopsis } \\
\text { biapiculata }\end{array}$} & & & & $\begin{array}{c}4-5,145-147 \mathrm{~cm} \\
\text { to } \\
3-1,5-7 \mathrm{~cm}\end{array}$ & $\begin{array}{c}24-1,138-140 \mathrm{~cm} \\
\text { to } \\
29-1,45-47 \mathrm{~cm}\end{array}$ \\
\hline Eocene & $\begin{array}{l}\text { Dictyocha } \\
\text { deflandrei }\end{array}$ & $\begin{array}{c}\text { Naviculopsis } \\
\text { trispinosa } \\
\text { Subzone } \\
\end{array}$ & & $\begin{array}{c}4-3,81-83 \mathrm{~cm} \\
\text { to } \\
4-1,147-149 \mathrm{~cm} \\
\end{array}$ & & $\begin{array}{c}5-3,65-67 \mathrm{~cm} \\
\text { to } \\
5-1,147-149 \mathrm{~cm} \\
\end{array}$ & \\
\hline \multirow[b]{2}{*}{ Paleocene } & \multicolumn{2}{|c|}{ Naviculopsis constricta } & $\begin{array}{c}6-1,14-16 \mathrm{~cm} \text { to } \\
5-1,45-48 \mathrm{~cm}\end{array}$ & & & & \\
\hline & \multicolumn{2}{|c|}{ Corbisema hastata } & $\begin{array}{l}8-3,12-14 \mathrm{~cm} \text { to } \\
6-1,102-103 \mathrm{~cm}\end{array}$ & & & & \\
\hline
\end{tabular}

silicoflagellate biostratigraphy did not appear until 1960 when Mandra dated silicoflagellate assemblages in his studies of late Maestrichtian, late Eocene, Miocene, and Miocene-Pliocene deposits of California. The next year, 1961, Stradner published a paper on the Oligocene silicoflagellates of Austria. Glezer (1966) presented "Cryptogamic plants of the U.S.S.R.," which covers the distribution of Late Cretaceous through Cenozoic silicoflagellates in the USSR and which summarizes much previous information on morphology, taxonomy, and ecology. Ling's (1972) report is an invaluable updated synthesis of silicoflagellate taxonomy. Loeblich et al. (1968) give the original descriptions of all validly proposed genera and species up until that publication. It is not a systematic revision, and all of the species are listed under their original names, although these may no longer be in general use. This compilation formed a useful departure point for more recent taxonomic and stratigraphic studies which have resulted from the exploratory activities of Glomar
Challenger. Systematic investigations of DSDP material, particularly those by Bukry, have proven the stratigraphic utility of silicoflagellates in marine sediment (for example see Bukry, 1975a, b, c).

Paleotemperature studies utilizing silicoflagellates are relatively new. As mentioned by Glezer (1966), this is probably because silicoflagellates comprise such a small percentage of the total planktonic population in present-day oceans. Even in the early part of this century, however, Gemeinhardt $(1931,1934)$ recognized their biogeographic provinciality and associated it with salinity and temperature. Mandra (1958) was the first to try to use the Dictyocha to Distephanus ratio in order to obtain paleotemperatures. The relationship of the occurrence of the species of these two genera to water temperature had been recognized for a long time (Schulz, 1928; Gemeinhardt, 1931, 1934; ProshkinaLavrenko, 1959). Martini (1971) developed a scheme for relating the surface water temperature to the Dictyocha fibula to Distephanus speculum ratio; he chose 
these two species because they are the most abundant in present-day waters. Ciesielski and Weaver (1973) found that the paleotemperature curves they derived from the application of Mandra's method in Southern Ocean cores produced temperatures too high for this region. Ciesielski (1975) therefore determined the ratio of Dictyocha to Distephanus in surface sediment cores of Recent sediment from the Southern Ocean and correlated this with the known mean annual temperature of the overlying water mass to produce a curve in better agreement with the temperatures observed in this region. Thus it is now becoming possible to use silicoflagellates as a means for determining paleotemperature.

It is important, however, to be aware of possible complications and limitations in the use of silicoflagellates to determine paleotemperatures. Poelchau (1974) points out the importance of the position of the thermocline with respect to the vertical zonation of the warm- and cold-water genera. He found in the Pacific that the surface sediments contain an overabundance of Dictyocha, which lived in the warmer waters above the thermocline. Distephanus, which lived below the thermocline, was depleted in relative numbers in the sediment. Poelchau believes this to be a result of preferential near-surface grazing with inclosure of the warm-water, upper level Dictyocha in fecal pellets. This facilitates their rapid burial before they can be dissolved. Since the position of the thermocline varies from one area to another, any surface water to surface sediment calibrations of warm-water to cold-water ratios of genera would be extremely provincial, necessitating reexamination of the ratios in each new region studied. The Southern Ocean may be something of an exception because of unusual hydrographic conditions. During the winter months the upper water mass is homogeneous so that selective grazing would not be a factor. During the remainder of the year, however, the water has a temperature minimum that fluctuates between 50 and 250 meters, increasing below this in temperature to a temperature maximum at the surface of the circumpolar deep water (Gordon, 1967). This may have interesting implications for generic homogeneity in the photic zone. Basically, however, it seems that the surface waters south of the Polar Front are sufficiently homogeneous throughout the year that selective grazing would do little to affect the silicoflagellate ratios in the underlying sediment. For this reason, the calibration done by Ciesielski (1975) for the region should be reliable.

Because silicoflagellates are far less numerous than other planktonic groups, such as the diatoms or coccoliths, they have been relatively neglected by micropaleontologists until recently. But with the development of workable biostratigraphies and their emerging utility as ecological indicators, they are gaining recognition as important micropaleontological indices.

\section{BIOSTRATIGRAPHY}

The increasing number of silicoflagellate reports, especially in the Initial Reports of the Deep Sea Drilling
Project, are beginning to provide a solid basis for the comparison and correlation of various silicoflagellate zonations. It is now becoming possible to discern regional trends and to trace the paleobiogeography of silicoflagellates.

The Paleocene, Eocene, and Oligocene are best represented in the Southern Ocean sections recovered to date. The genera Corbisema and Naviculopsis predominate in these older assemblages, and abundant and diverse flora have been observed. The Miocene, Pliocene, and Pleistocene are represented by a more diverse and abundant flora in the subtropical and tropical regions and are predominantly composed of the genera Distephanus and Dictyocha. The Distephanus speculum group, including all forms and varieties of Distephanus speculum, is common to all regions but far more morphologic forms are found in the tropical and subtropical assemblages.

The middle and upper Miocene assemblages show the greatest divergence between the various regions. This is in sharp contrast to lower Miocene assemblages, which appear more cosmopolition the world over (Ciesielski, 1975), probably due to the existence of a more equitable climatic condition during the early Miocene than subsequently. The Corbisema triacantha Zone is the only zone which appears to be cosmopolitan. These various biogeographic trends are evident in the summary and comparison of silicoflagellate zonations presented in Table 2.

\section{PALEOENVIRONMENT}

A brief history of the development of paleotemperature studies utilizing silicoflagellates appears in the historical section. The method discussed there for determining absolute paleotemperatures first developed by Mandra (1958) and later refined by Ciesielski and Weaver (1973), however, could not be applied to any of the material studied in DSDP Leg 36 because of the low number of silicoflagellates found in the Pliocene and Pleistocene material. Nevertheless, a method for determining relative paleotemperatures developed by Kanaya and Koizumi (1966) for diatoms could be applied on a limited basis. Because so many of the silicoflagellate taxa found in the Miocene and Oligocene are no longer living, the absolute paelotemperature technique is not applicable. However, as suggested by Kanaya and Koizumi's (1966) study, the relative warm- and cold-water tolerances of the various taxa can be derived from the biogeographic distribution of extinct taxa and from observation of their still extant representatives.

The relative paleotemperature is determined using this formula:

$$
T_{d}=\frac{w_{w}}{X_{w} \cdot X_{c}} \cdot 100
$$

where $T d$ is the relative paleotemperature determinations, $X w$ the number of specimens belonging to the warm-water genera, and $X c$ the number of 
specimens belonging to the cold-water genera. The cold-water genera include Distephanus and Cannopilus, and the warm-water genera include Corbisema, Dictyocha, and Naviculopsis. Mesocena is considered to be intermediate in temperature and is counted with both the cold- and warm-water genera.

The problem encountered is that the determinations thus obtained are influenced greatly by the number of specimens available to count. Although the Miocene species are generally more abundant than the Pliocene and Pleistocene silicoflagellates, the number observed is still often less than the 100 counts considered to be statistically valid.

A slight warming trend was seen in the Mesocena circulus Zone, with the temperatures becoming steadily colder up through the Mesocena circulus/Mesocena diodon Zone (Table 3). Not only is this trend supported by the coccolith data (Wise and Wind, this volume), but it may also explain why Ciesielski (1975) found no assemblages of the Mesocene circulus/Mesocena diodon Zone. Since Ciesielski's samples were recovered from the Ross Sea near Antarctica, a drop in temperature and consequent enlargement of Antarctic glacial ice would increase Antarctic Bottom Water production. The hiatus observed above his Mesocena circulus Zone would then be a result of the increase in bottom current activity, which would remove the material closer to the Antarctic continent. Since the Falkland Plateau material studied in this report was further removed from the effects of this scouring bottom water, the Mesocena circulus/Mesocena diodon Zone material could be deposited. The generally cold waters of the late Miocene are also reflected in the low abundance and poor to fair preservation of the silicoflagellates.

The late Oligocene relative paleotemperatures were also calculated from Hole 328B (Table 4). The temperature appears to be very cold up to the top of Core 3 where it suddenly warms dramatically. The low temperature readings could explain why no upper Oligocene was present in Ciesielski's DSDP Site 274. In our case, however, the abundances of silicoflagellates on the Falkland Plateau are very high and the preservation is quite good. Bukry (1975b) defined the upper Oligocene Naviculopsis biapiculata Zone in his DSDP Leg 29 report from the southwest Pacific Ocean. The relative paleotemperature calculated from Bukry's material (see Table 5) also indicates cold-water conditions, and the abundance is quite high, probably due to upwelling conditions produced with the changes in circulation patterns that accompanied the separation of Antarctica and Australia.

Both the late Oligocene and late Miocene temperature trends indicated by the silicoflagellates are supported by oxygen isotope studies of open-ocean benthonic and planktonic foraminifera from DSDP cores (Savin et al., 1975).

\section{ZONATION}

The upper Tertiary zones described herein, except for the Mesocena circulus/M. diodon Zone, were first described from the Southern Ocean (Ciesielski, 1975). Those are the Distephanus speculum A Zone, D. speculum B. Zone, and the Mesocena circulus Zone (emended herein). The $M$. circulus $/ M$. diodon Zone is a new zone.

The lower Tertiary zones are those described by Bukry (1974) and Bukry and Foster (1974). Occurrences of the older Tertiary material are rare, and the assemblages appear to be more cosmopolitan due to more equitable climates. These zones were described from a synthesis of DSDP cores, and they include the Naviculopsis biapiculata Zone (Bukry, 1974) and the Dictyocha deflandrei, Naviculopsis constricta, and Corbisema hastata zones (Bukry and Foster, 1974).

\section{Distephanus speculum A Zone}

Top: Undefined; the zone above the initial consistently common occurrence of long-spined Distephanus speculum.

Base: The first consistently common occurrence of long-spined and short-spined Distephanus speculum speculum in the absence of Distephanus boliviensis.

Author: Ciesielski, 1975.

Age: Early Pleistocene-Recent.

Zonal assemblage: Characteristic of this zone is the common occurrence of long-spined and short-spined Distephanus speculum speculum. Also present are Distephanus speculum pentagonus, Dictyocha aspera, Distephanus speculum septenarius, Distephanus speculum octonarius, and Dictyocha fibula.

Remarks: This zone is present in the upper parts of Holes 328, 328A, and 328B where the silicoflagellate flora is sparse and poorly preserved.

\section{Distephanus speculum B Zone}

Top: First consistently common occurrence of longspined Distephanus speculum speculum in the absence of Distephanus boliviensis.

Base: Last consistently common occurrence of Distephanus boliviensis along with predominantly shortspined Distephanus speculum speculum.

Author: Ciesielski, 1975.

Age: Late Pliocene.

Zonal assemblage: This zone is characterized by the consistently common to abundant presence of shortspined Distephanus speculum speculum and rare to few long-spined Distephanus speculum speculum. Also present are Dictyocha pseudofibula, Dictyocha aspera, Dictyocha fibula, Distephanus boliviensis, Distephanus sp. cf. boliviensis, Distephanus speculum pentagonus, and Distephanus polyactis.

Remarks: This zone was observed in Holes 328 and 328B. The silicoflagellate flora is neither well preserved nor abundant.

\section{Mesocena circulus/Mesocena diodon Zone}

Top: Last consistent occurrence of Mesocena circulus.

Base: First consistent occurrence of Mesocena diodon.

Authors: Busen and Wise, this paper.

Reference section: Sample 329-1-3, $30 \mathrm{~cm}$ to $329-12-$ $3,30 \mathrm{~cm}$.

Age: Middle-late Miocene.

Zonal assemblage: This zone is characterized by the common occurrence of Mesocena circulus and Mesocena diodon. Mesocena diodon is less common 
TABLE 2

Summary and Comparison of Silicoflagellate Zonations

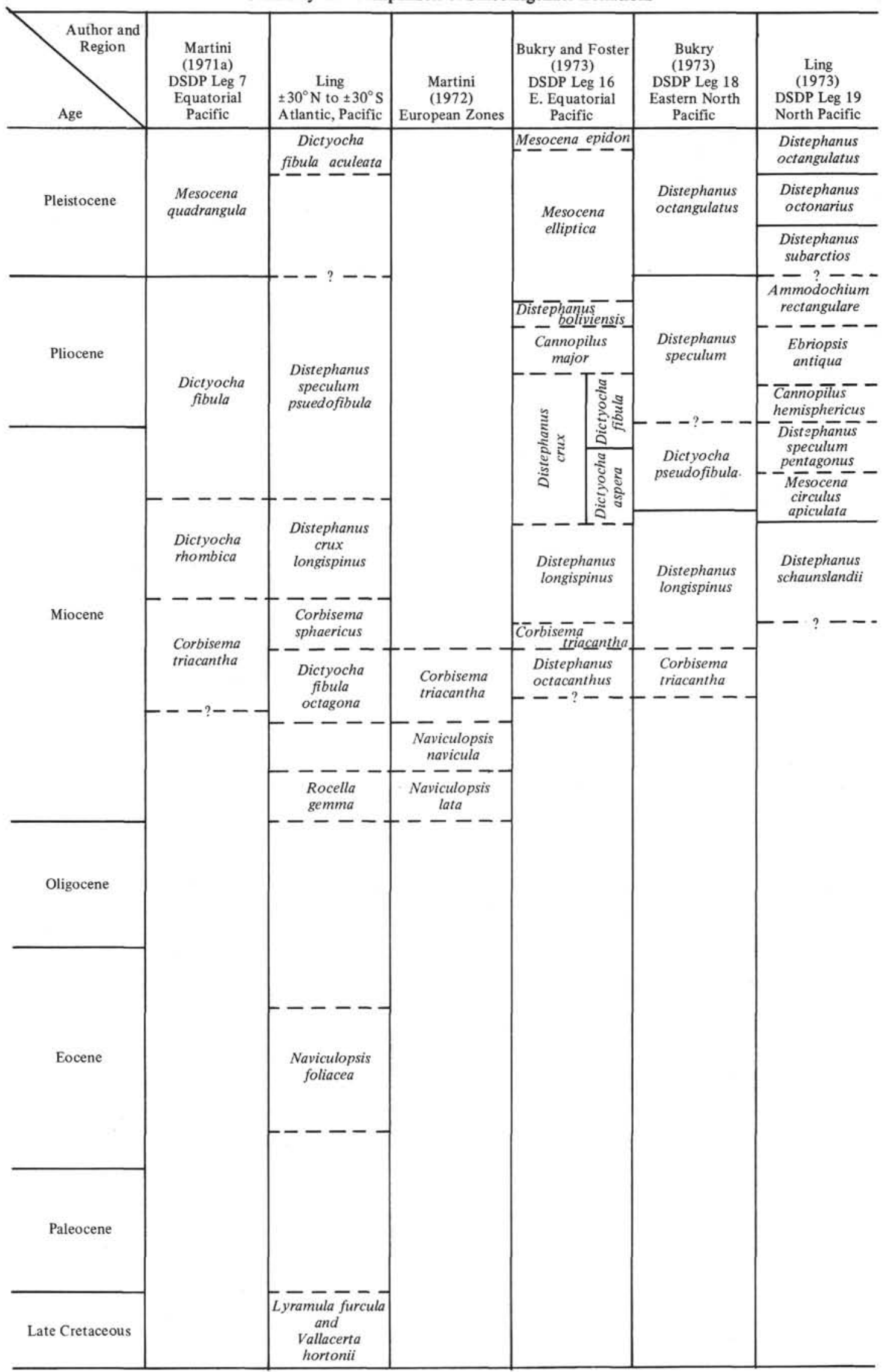


TABLE 2 - Continued

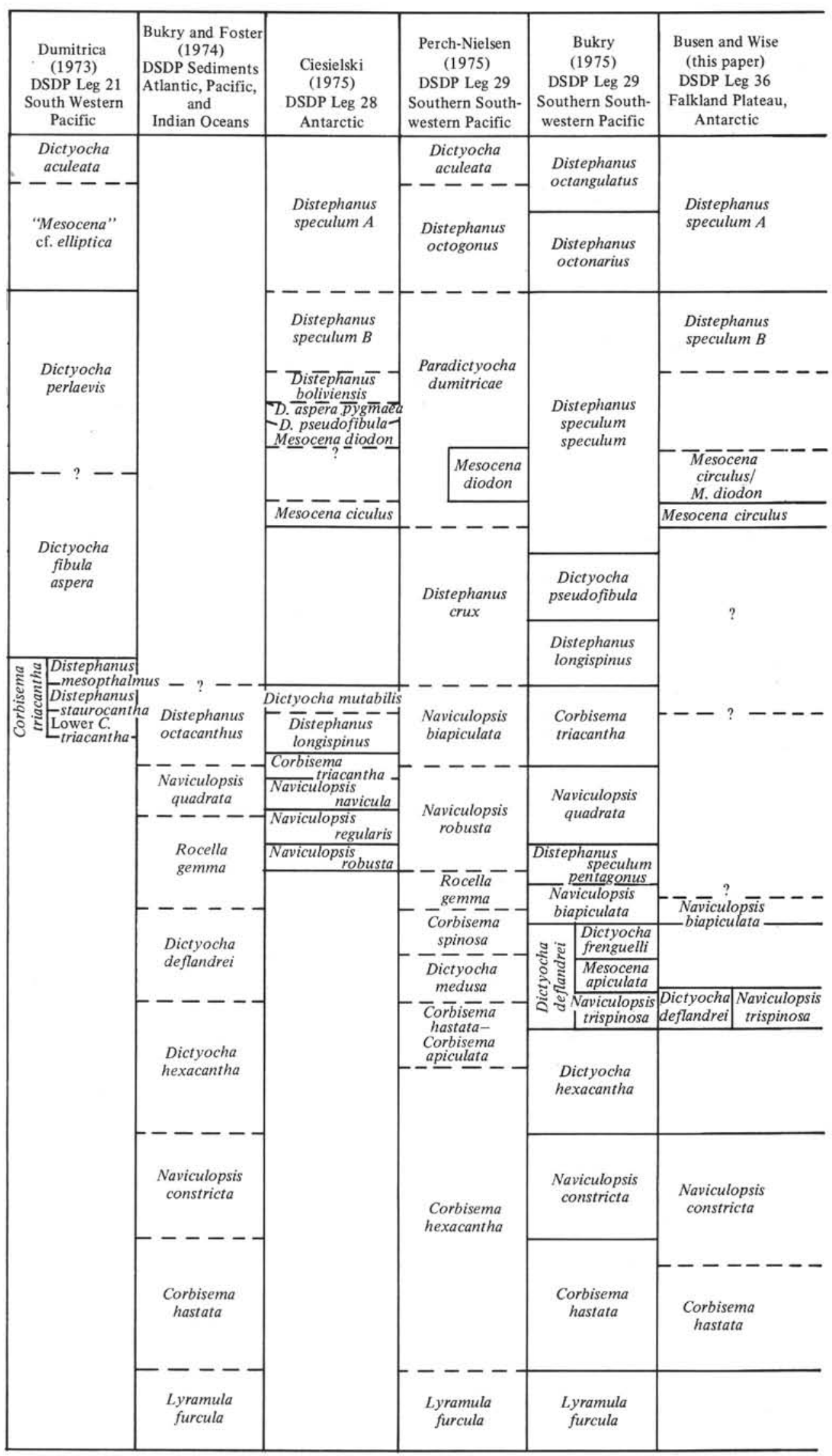


TABLE 3

Relative Paleotemperature Determinations for Site 329, DSDP Leg 36

\begin{tabular}{ccc}
\hline $\begin{array}{c}\text { Core- } \\
\text { Section }\end{array}$ & $\begin{array}{c}\text { Total } \\
\text { Specimens }\end{array}$ & $\mathrm{T}_{\mathrm{D}}$ \\
\hline $1-1$ & 119 & 0.85 \\
$4-3$ & 60 & 1.82 \\
$5-1$ & 94 & 1.17 \\
$6-1$ & 78 & 1.37 \\
$7-4$ & 115 & 0.87 \\
$8-3$ & 246 & 0.41 \\
$9-1$ & 61 & 1.64 \\
$9-3$ & 70 & 1.51 \\
$10-4$ & 57 & 1.75 \\
$12-1$ & 76 & 1.37 \\
$12-3$ & 79 & 1.31 \\
$13-3$ & 24 & 4.35 \\
$14-2$ & 45 & 2.63 \\
\hline
\end{tabular}

TABLE 4

Relative Paleotemperature Determinations for Site 328B, DSDP Leg 36, Upper Oligocene

\begin{tabular}{lrr}
\hline $\begin{array}{c}\text { Sample } \\
\text { (Interval in cm) }\end{array}$ & $\begin{array}{c}\text { Total } \\
\text { Specimens }\end{array}$ & \multicolumn{1}{c}{$\mathrm{T}_{\mathrm{D}}$} \\
\hline 3-1, 5-7 & 196 & 21.96 \\
$3-1,145-147$ & 45 & 3.70 \\
$3-2,70-72$ & 60 & 3.94 \\
$3-3,5-7$ & 73 & 3.03 \\
$3-4,70-72$ & 219 & 0.89 \\
$3-5,143-145$ & 293 & 0.68 \\
$3-6,70-72$ & 312 & 0.95 \\
$4-1,45-47$ & 305 & 0.72 \\
$4-2,5-7$ & 334 & 0.72 \\
$4-3,145-147$ & 321 & 0.54 \\
$4-5,3-5$ & 334 & 0.65 \\
\hline
\end{tabular}

TABLE 5

Relative Paleotemperature Determinations for Site 278, DSDP Leg 29, Upper Oligocene (data from Bukry, 1975)

\begin{tabular}{ccc}
\hline $\begin{array}{c}\text { Sample } \\
\text { (Interval in cm) }\end{array}$ & $\begin{array}{c}\text { Total } \\
\text { Specimens }\end{array}$ & $\mathrm{T}_{\mathrm{D}}$ \\
\hline $30-1,113$ & 300 & 1.17 \\
$31-1,72$ & 600 & 0.82 \\
$31-2,75$ & 300 & 1.31 \\
$31-3,75$ & 400 & 1.20 \\
\hline
\end{tabular}

than Mesocena circulus. Also present are short-spined Distephanus speculum speculum, Dictyocha aspera, Distephanus boliviensis, Distephanus speculum pentagonus, and Distephanus crux hannai.

Remarks: This zone was encountered only at Site 329, and the occurrence of Mesocena circulus and Mesocena diodon has at present been observed only at this site. However, the preservation and abundance of the name species are fairly good in this hole and there is no evidence of reworking.

\section{Mesocena circulus Zone}

Top: First occurrence of Mesocena diodon.

Bottom: First consistent occurrence of Mesocena circulus.

Author: Ciesielski, 1975; here emended.

Age: Late middle to late Miocene.

Zonal assemblage: This zone is characterized by the consistent appearance of Mesocena circulus. Shortspined Distephanus speculum speculum also appear consistently. Other species present include Distephanus crux, crux, Dictyocha fibula, and Dictyocha aspera.

Remarks: Few silicoflagellates were present in this zone and preservation is poor at Leg 36 sites. The definition of the top of this zone is emended because Mesocena diodon and $M$. circulus were discovered occurring together consistently at Site 329. Ciesielski (1975) noted a hiatus between his Mesocena circulus and Mesocena diodon zones. It appears that the Mesocena circulus/Mesocena diodon Zone is missing in his area due to strong bottom current activity associated with glacial climate conditions. Thus it seems reasonable that the overlap in ranges of Mesocena diodon and $M$. circulus would be recorded at more northerly sites further removed from the paleoice front of the Antarctic continent.

\section{Naviculopsis biapiculata Zone}

Top: Not defined; taken here as last common occurrence of Naviculopsis biapiculata.

Base: First common occurrence of Naviculopsis biapiculata and last common occurrence of Dictyocha deflandrei.

Author: Bukry, 1974.

Age: Late Oligocene.

Zonal assemblage: This zone is characterized by the occurrence of common to abundant Naviculopsis biapiculata and Distephanus crux crux. Also present are Naviculopsis constricta, Naviculopsis trispinosa, Distephanus boliviensis, Mesocena oamaruensis, Mesocena occidentalis, short-spined Distephanus speculum speculum, Corbisema triacantha, Corbisema apiculata, Mesocena apiculata, Dictyocha frenguelli, Dictyocha deflandrei, and Distephanus crux fenestratus.

Remarks: This zone was observed in Holes 328 and 328A. Naviculopsis constricta appears to be long ranging at this site. The Distephanus speculum present are quite small. The Mesocena species are quite abundant. Two types of Distephanus crux are present. In the lower part of the zone Distephanus crux tends to possess exceptionally long radial spines along one axis. In the upper part of the zone Distephanus crux fenestratus, the small-windowed variety, replaces Distephanus crux crux in abundance.

\section{Dictyocha deflandrei Zone}

Top: Last consistent occurrence of Dictyocha deflandrei.

Base: First consistent occurrence of Dictyocha deflandrei above the last common occurrence of Dictyocha hexacantha.

Author: Bukry and Foster, 1974.

Age: Late Eocene.

Zonal assemblage: This zone is characterized by the consistent occurrence of Dictyocha deflandrei above the 
last common occurrence of Dictyocha hexacantha. Three subzones can be differentiated within this zone. They are the Dictyocha frenguelli Subzone, the Mesocena apiculata Subzone, and the Naviculopsis trispinosa Subzone. The material examined in this study falls within the Naviculopsis trispinosa Subzone which is the oldest of the three. This subzone is characterized by the initial occurrence of Naviculopsis trispinosa and the predominance of Naviculopsis constricta over Mesocena apiculata above the last common occurrence of Dictyocha hexacantha. Naviculopsis biapiculata, Corbisema hastata, Corbisema triacantha, Corbisema apiculata, Dictyocha fibula, Distephanus crux crux, Distephanus speculum pentagonus, Mesocena oamaruensis, Mesocena occidentalis, and Dictyocha fallacia are also present.

Remarks: This subzone is present in Holes 328 and 328B. The late Eocene age of this material has been confirmed by the radiolarian data. Rare to few Dictyocha deflandrei are present. The Distephanus speculum pentagonus present tend to be robust forms with smaller windows than the younger Distephanus speculum pentagonus. The preservation and abundance of the silicoflagellates is excellent.

\section{Naviculopsis constricta Zone}

Top: The first common occurrence of Dictyocha hexacantha and the rare but consistent occurrence of Dictyocha deflandrei.

Base: First consistent common occurrence of Naviculopsis constricta.

Author: Bukry and Foster, 1974.

Age: Late Paleocene.

Zonal assemblage: This zone is characterized by the first consistent common occurrence of Naviculopsis constricta. Also occurring are Corbisema apiculata, Corbisema arkangelskiana, Corbisema geometrica, Corbisema hastata, Corbisema inermis disymmetrica, Corbisema triacantha, Dictyocha fibula, Corbisema navicula navicula, Corbisema cuspis, and Naviculopsis biapiculata.

Remarks: This zone was present in Hole 327A. It was difficult to determine the base of this zone as the increase in abundance of Naviculopsis constricta did not show a sharp break but rather a steady increase upward through the zone. The appearance of a new species, Corbisema cuspis, was used in conjunction with the abundance of Naviculopsis constricta to determine the base of the zone. The relationship between the genera Naviculopsis and Corbisema and the problems presented by this relationship are discussed in the taxonomy section.

\section{Corbisema hastata Zone}

Top: First common occurrence of Naviculopsis constricta.

Base: First occurrence of Corbisema hastata.

Author: Bukry and Foster, 1974.

Age: Middle-late Paleocene.

Zonal assemblage: This zone is characterized by the first appearance of Corbisema hastata before the first common occurrence of Naviculopsis constricta. Other species present are Corbisema geometrica, Corbisema inermis disymmetrica, and Corbisema apiculata.
This zone was exceptionally well preserved in Hole 327 A.

\section{SITE SUMMARIES}

Hole 327A

(lat $50^{\circ} 52.28^{\prime} \mathrm{S}$, long $46^{\circ} 47.02^{\prime} \mathrm{W}$, depth $2401 \mathrm{~m}$ )

Site $327 \mathrm{~A}$ is located at the eastern end of the Falkland Plateau. The purpose of drilling this site was to determine the age and composition of Cretaceous and lower Tertiary acoustic-reflector horizons.

Most of Sample 327A-1-1, $129 \mathrm{~cm}$ contains a sparse silicoflagellate flora of mixed Miocene to Recent age (see Table 6). The Distephanus speculum group dominates. The lower part of Core 1 and all of Cores 2 and 3 were found to be barren of silicoflagellates; zeolites are plentiful.

Core 5 and the upper part of Core 6 contain an abundant and diverse silicoflagellate flora of late Paleocene to early Eocene age, which comprises the Naviculopsis constricta Zone. Species of the genus Corbisema dominate. The remaining portion of Core 6, all of Core 7 , and part of Core 8 contain the Corbisema hastata Zone, middle to late Paleocene in age. The silicoflagellates are abundant, diverse, and well preserved.

The lower portion of Core 8 is barren of silicoflagellates; zeolites are abundant. Site 327 is of considerable interest because it offered the first opportunity to study a continuous section showing the transition between the Corbisema hastata and Naviculopsis constricta zones. Unfortunately, the first common occurrence of Naviculopsis constricta is not as definitive as it originally appeared to be before the transitional section was discovered. We used more both the common and consistent occurrence of Naviculopsis constricta and the appearance of another new species, Corbisema cuspis, to separate this zone from the older Corbisema hastata Zone. As all the other species studied are long ranging and consistent through both zones, the present zonal definitions remain the best available.

\section{Holes 328, 328A, and 328B}

\section{(lat $49^{\circ} 48.67^{\prime} \mathrm{S}$, long $36^{\circ} 39.53^{\prime} \mathrm{W}$, depth $5013 \mathrm{~m}$ )}

Site 328 is located east of the Falkland Plateau in the Malvinas Outer Basin where Antarctic Bottom Water formed in the Weddell Sea flows into the Argentine Basin. It was cored to provide a deep-water section for comparison with the Falkland Plateau material and to attempt to determine the onset of the Antarctic circumpolar current.

Core 1 of Hole 328 contains a sparse but consistent silicoflagellate flora of the Distephanus speculum A Zone (Pleistocene to Quaternary age; see Table 7). Core 2 and the upper portion of Core 3 contain the Distephanus speculum B Zone of late Pliocene age. The flora is more abundant and better preserved than the younger Pleistocene material. This zone is dominated by the Distephanus speculum group, but is differentiated from the above zone by the relatively less frequent appearance of long-spined Distephanus speculum speculum with respect to the short-spined Distephanus speculum speculum. 
TABLE 6

Distribution of Silicoflagellates, Hole 327A

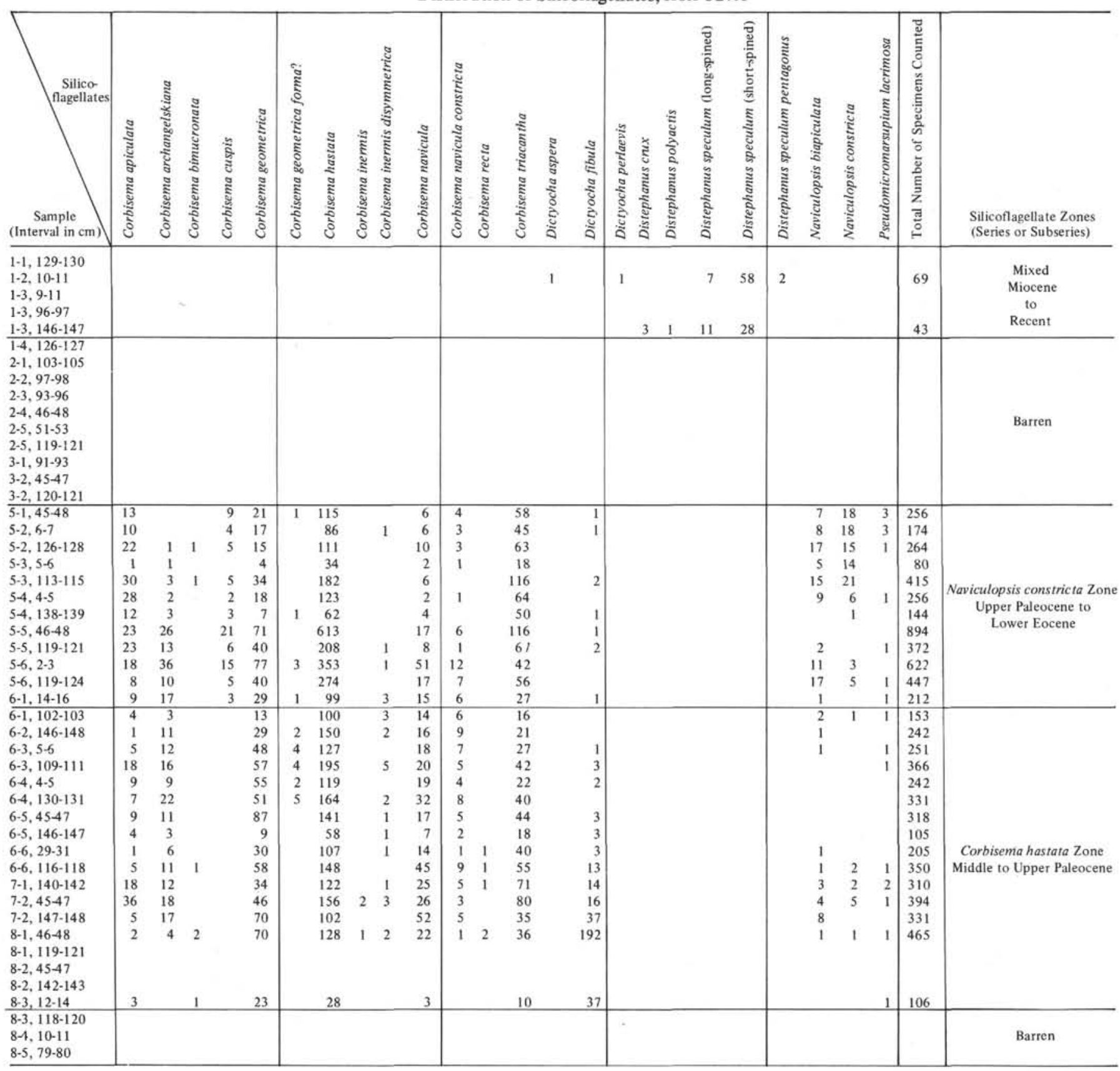


Core 3 is barren except for the interval from Section $2,140 \mathrm{~cm}$ to Section $4,5 \mathrm{~cm}$ which is probably Miocene although the silicoflagellate flora is too sparse and poorly preserved to make a positive identification.

The upper portion of Core 4 contains the Naviculopsis trispinosa Subzone of the Dictyocha deflandrei Zone, which is late Eocene in age. Mesocena species are abundant, Naviculopsis species are common, and Corbisema species occur consistently. Distephanus crux crux and Distephanus crux fenestratus are the only two Distephanus species consistently present whereas Dictyocha fallacia and Dictyocha fibula are the only Dictyocha species to occur consistently in this interval. The silicoflagellate flora is abundant, diverse, and well preserved.

Cores 1 and 2 of Hole 328A yielded a rather sparse silicoflagellate assemblage of the Distephanus speculum A Zone of Pleistocene to Quarternary age (Table 4). There may be some late Pliocene material at the bottom of Core 2, but the flora there is too sparse to allow a positive determination.

Hole 328B down to Sample 328B-1-2, $70 \mathrm{~cm}$ contains a generally sparse flora of the Distephanus speculum A Zone (Pleistocene to Recent; Table 7A). This zone can be identified because the bottom interval, 328B-1-2, 70$72 \mathrm{~cm}$, does have a fairly large number of wellpreserved specimens so that delineation of the zone is possible. Material in the uppermost portion of the core is broken and sparse in abundance. The remainder of Core 1 and the upper portion of Core 2 at Site 328B is assigned to the Distephanus speculum B Zone, late Pliocene in age. The few silicoflagellates present are poorly preserved. The remainder of Core 2 at Site 328B is barren.

Cores 3 and 4 of Hole 328B are comprised of excellent upper Oligocene material of the Naviculopsis biapiculata Zone. The flora is abundant, well preserved, and quite diverse. Mesocena apiculata, Naviculopsis biapiculata, Distephanus crux crux, and Distephanus crux fenestratus are the major components of this assemblage.

Although the top and bottom portions of Core 5 are barren of silicoflagellates, the interval from Sample $328 \mathrm{~B}-5-4,29 \mathrm{~cm}$ to $328 \mathrm{~B}-5-3,65 \mathrm{~cm}$ contains a short but well preserved and fairly abundant section of upper Eocene material of the Naviculopsis trispinosa Subzone of the Dictyocha deflandrei Zone.

\section{Site 329}

(lat $50^{\circ} 39.31^{\prime} \mathrm{S}$, long $4^{\circ} 05.73^{\prime} \mathrm{W}$, depth $1519 \mathrm{~m}$ )

Site 329 is located on the eastern end of the Falkland Plateau, upslope from Site 327. It was cored to determine the age of the Neogene strata, to compare with the deep-water Site 328 , and to study paleocirculation.

Cores 1 through 12 contain the Mesocena circulus/Mesocena diodon Zone (defined herein) which is late Miocene in age (Table 8). Hitherto, Mesocena circulus and Mesocena diodon had not been found to occur simultaneously. The zone may be provincial, present only in this region. On the other hand, it may not be present at DSDP Leg 28 sites due to a hiatus in the sections in the Ross Sea area. The short-spined Dis- tephanus speculum speculum is the predominant component of the assemblage, along with Mesocena circulus and Mesocena diodon. Preservation and abundance of specimens are quite uneven in the section studied.

Cores 14 through 15 are assigned to the Mesocena circulus Zone, which is middle to late Miocene in age. Abundance is quite low and preservation fair to poor.

Cores 16 through 19 are probably Miocene in age although it is difficult to assign a zone because of low abundance and diversity and only fair preservation. Short-spined Distephanus speculum speculum, Dictyocha fallacia, and Dictyocha fibula are the most abundant members of this interval.

Cores 24 through 29 contain the Naviculopsis biapiculata Zone, which is late Oligocene in age. Although Naviculopsis biapiculata is not present in Cores 24 and 26, other important members of the zonal assemblage such as Distephanus crux crux and Mesocena apiculata are present. Preservation here is better than it is in the rest of the core.

\section{Site 330 \\ (lat $50^{\circ} 55.19$ 'S, long $46^{\circ} 53.00^{\prime} \mathrm{W}$, depth $262 \mathrm{~m}$ )}

Site 330 is located on the eastern end of the Falkland Plateau. Core 1 of Hole 330A contained mixed Eocene to Recent material.

\section{Site 331}

(lat $37^{\circ} 53.00^{\prime} \mathrm{S}$, long $38^{\circ} 06.92 ' \mathrm{~W}$, depth $5067 \mathrm{~m}$ )

Site 331 is located in the Argentine Basin. It was aborted because of mechanical problems and bad weather. Only poorly preserved Quaternary material was recovered.

\section{SYSTEMATIC PALEONTOLOGY}

Unless otherwise noted, all age occurrences mentioned apply only to ranges observed in DSDP Leg 36 cores. Bibliographic references for most taxa are provided by Loeblich et al., 1968. Any not cited there are given in the References section.

\section{Order SIPHONOTESTALES Lemmermann, 1901}

Genus CORBISEMA Hanna, 1928, emend. Frenguelli, 1940

Remarks: There has been some discussion concerning the definition of this genus, particularly its differentiation from the genus Dictyocha. The emended definition given by Frenguelli (1940, p. 69) and accepted by Deflandre 1950a, p. 47/82) is followed here.

The genus Corbisema was originally defined by Hanna (1928) to have a triangular basal ring. Although this characteristic shape is helpful in immediately distinguishing many of the Corbisema species, the genus now includes forms which possess two, four, or more sides to the basal ring provided that other morphological elements particular to this genus are present. The basal ring is formed of hollow rods, usually possessing a septate lumen at the corners. The apical structure is simple, generally without apical windows although an apical plate is not uncommon. The position of the sustaining spines was considered by Frenguelli and Deflandre to be critical and is considered so here. In the genus Corbisema the sustaining spines are directly connected to the lateral bars, distinguishing it from the genus Dictyocha, which possesses basal accessory spines on the basal ring itself. Although the position of the sustaining spines is the single most distinguishing characteristic of this genus, this may occasionally be discounted if two or more of the other distinguishing morphological elements are present.

Even though the generic definition is extremely loose, in practice the identification of Corbisema is quite workable and should not be abolished, as has been suggested by some authors. 
TABLE 7A

Distribution of Silicoflagellates, Hole 328

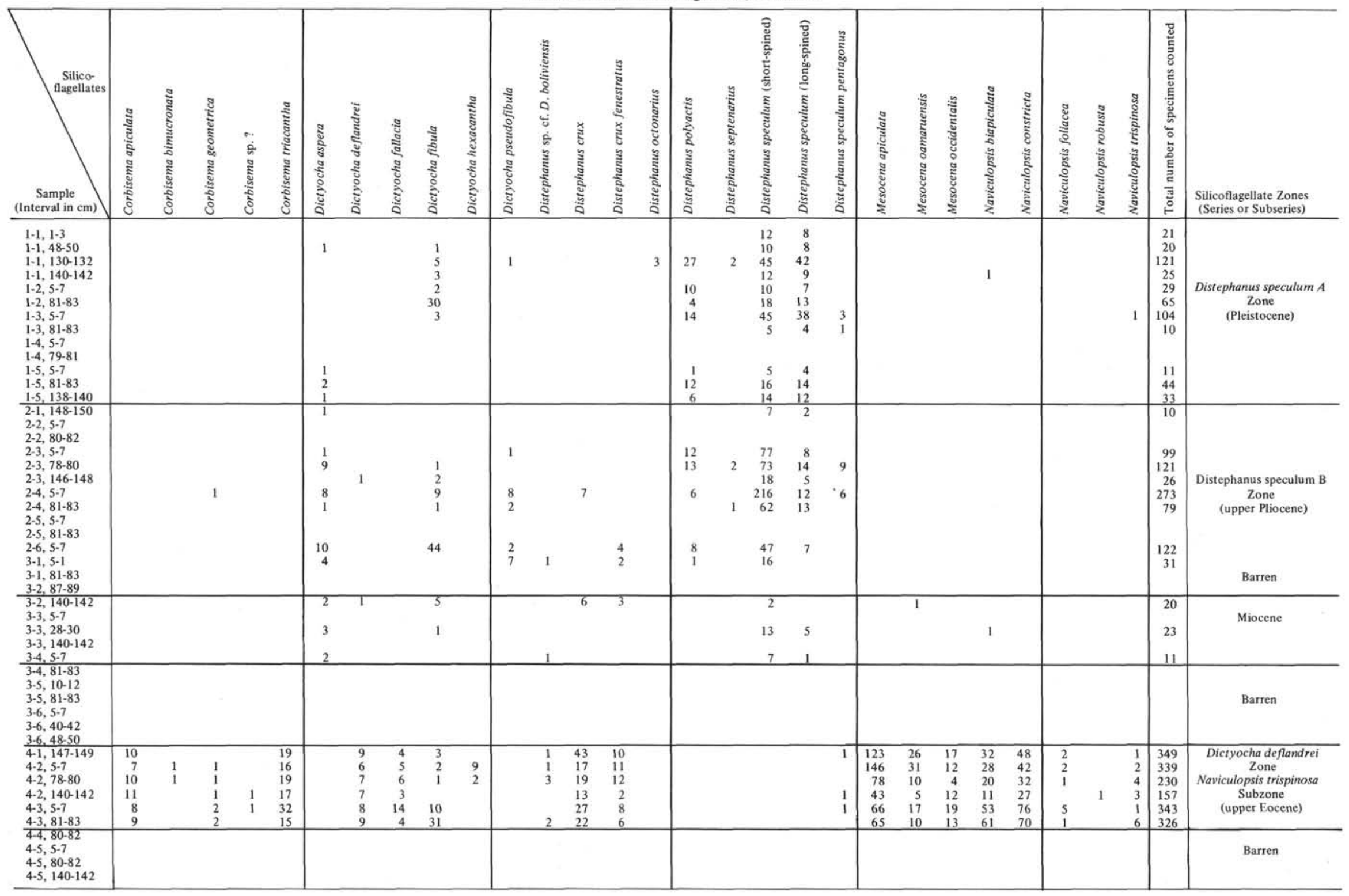


TABLE 7B

Distribution of Silicoflagellates, Hole 328B

\begin{tabular}{|c|c|c|c|c|c|c|c|c|c|c|c|c|c|c|c|c|c|c|c|c|c|c|c|c|c|c|c|c|c|c|c|c|c|}
\hline$\underbrace{\substack{\text { Silco- } \\
\text { (Interval in cm) }}}_{\substack{\text { Sample } \\
\text { nagellates }}}$ & 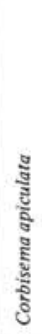 & $\begin{array}{l}\text { हूँ } \\
\text { है } \\
\text { है } \\
\text { है }\end{array}$ & 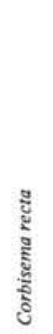 & 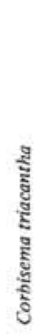 & $\begin{array}{l}\text { हूँ } \\
\text { हूँ } \\
\text { हैँ } \\
\text { है }\end{array}$ & 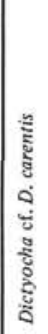 & 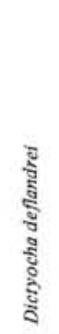 & 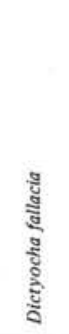 & $\frac{\frac{a}{3}}{\frac{3}{2}}$ & 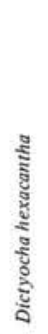 & 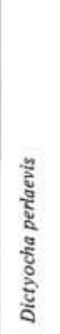 & 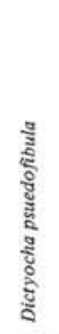 & 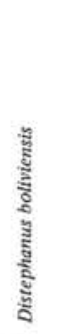 & 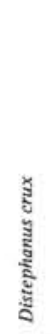 & 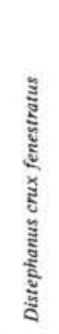 & 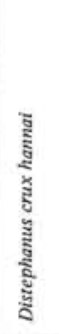 & 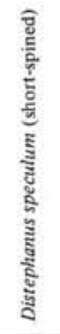 & 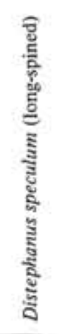 & 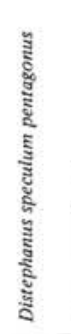 & 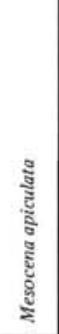 & 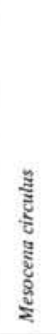 & 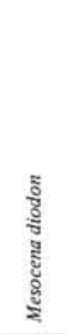 & $\begin{array}{l}\text { हूँ } \\
\text { हूँ } \\
\text { हूँ } \\
\text { हूँ }\end{array}$ & 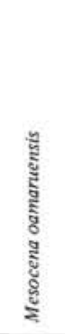 & 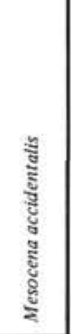 & 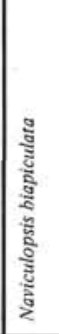 & 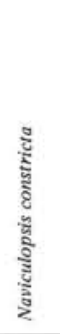 & 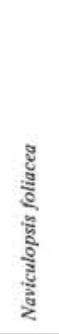 & 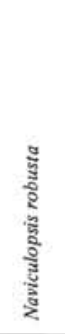 & 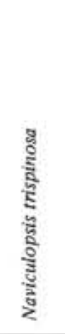 & 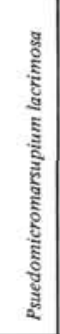 & 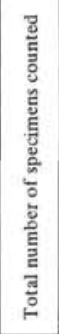 & $\begin{array}{l}\text { Silicoflagellate Zones } \\
\text { (Series or Subseries) }\end{array}$ \\
\hline $\begin{array}{l}1-1,89-91 \\
1-1,130-132 \\
1-2,5-7 \\
1-2,70-72\end{array}$ & & & & & 8 & & & & 10 & & & $\begin{array}{l}\mathrm{P} \\
\mathrm{P} \\
\mathrm{P} \\
\mathrm{P}\end{array}$ & & & & & $\begin{array}{l}\mathrm{P} \\
\mathrm{P} \\
\mathrm{P} \\
54\end{array}$ & $\begin{array}{l}\mathrm{P} \\
\mathrm{P} \\
\mathrm{P} \\
78\end{array}$ & 11 & & & & & & & & & & & & & \begin{tabular}{|c|}
$\mathrm{P}$ \\
$\mathrm{P}$ \\
$\mathrm{P}$ \\
172 \\
\end{tabular} & $\begin{array}{c}\text { Distephanus speculum A } \\
\text { Zone } \\
\text { (Quaternary) }\end{array}$ \\
\hline$\frac{1-3,5-7}{1-3,-7}$ & 3 & & & & & & & & $\frac{10}{18}$ & & & 1 & & & & & 34 & 8 & 11 & & & & & & & & & & & & & 65 & Distephanus speculum B \\
\hline $\begin{array}{l}1-3,70-72 \\
1-3,142-144\end{array}$ & & & & & ${ }_{4}^{6}$ & & & & ${ }_{8}^{9}$ & & & $\frac{1}{2}$ & & & & & ${ }_{35}^{25}$ & $\begin{array}{l}7 \\
8\end{array}$ & 1 & & & & & & & & & & & & & $\begin{array}{l}49 \\
58\end{array}$ & Zone \\
\hline $\begin{array}{l}1-3,4,5-7.144 \\
1-14\end{array}$ & & & & & 5 & & & & 5 & & & 2 & & 3 & & & 60 & 56 & & & & & 11 & & & & & & & & & 142 & (Upper Pliocene) \\
\hline $\begin{array}{l}1-4,147-149 \\
1-5,5-7\end{array}$ & & & & & ${ }_{3}^{2}$ & & & & ${ }_{7}^{3}$ & & & $\begin{array}{l}1 \\
3\end{array}$ & & $\frac{1}{7}$ & & 1 & $\begin{array}{l}45 \\
36\end{array}$ & $\begin{array}{l}23 \\
11\end{array}$ & & & & & 6 & & & & & & & & & $\begin{array}{l}81 \\
68\end{array}$ & \\
\hline $1-5,147-149$ & & & & & . & & & & . & & & 8 & & & & & 16 & 24 & & & & & & & & & & & & & & 51 & \\
\hline $1-6.7072$ & & & & & 36 & & & & 22 & & 24 & 15 & & & & & 20 & & & & & & & & & & & & & & & 139 & \\
\hline $\begin{array}{l}1-6,140-142 \\
2-1,5-7\end{array}$ & & & & & 18 & & & & & & 3 & 7 & & & & & $\stackrel{27}{\mathrm{P}}^{27}$ & P & 3 & & & & & 4 & & & & & & & & $\begin{array}{c}144 \\
P\end{array}$ & \\
\hline$\frac{2-1,144-146}{2-2,70-72}$ & 1 & & & 2 & 4 & & & & & & 4 & & & 5 & & & & 10 & & & 27 & 7 & & & & & & & & & & 87 & \\
\hline $\begin{array}{l}2-3,5-7 \\
2-3,143-147 \\
2-4,70-72 \\
2-5,5-7 \\
2-5,70-72 \\
2-6,5,-7 \\
2-6,123-125\end{array}$ & & & & & & & & & & & & & & & & & & & & & & & & & & & & & & & & & $\begin{array}{l}\text { Barren of } \\
\text { silicoflagellates }\end{array}$ \\
\hline $\begin{array}{l}\frac{1-0,12-125}{3-1,5-7} \\
3-1,145-147\end{array}$ & & & & & & & 3 & & & 3 & & 4 & & 4 & & 2 & 4 & 4 & 4 & $\begin{array}{l}32 \\
32\end{array}$ & & & & & & $\begin{array}{l}32 \\
15\end{array}$ & 4 & & 3 & & & 196 & \\
\hline $3-2,70-72$ & & & & 8 & 5 & & & & & & & & & 1 & 2 & 2 & 6 & 3 & 4 & 16 & & & & & & \begin{tabular}{|l}
15 \\
11
\end{tabular} & & & & & & $\begin{array}{l}45 \\
60\end{array}$ & Naviculopsis biapiculata \\
\hline $3-3,5-7$ & 1 & & & 3 & & & 2 & & 3 & & & & & 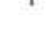 & 3 & & 10 & 5 & & 15 & & & & & & 23 & & & 5 & 3 & & 73 & \\
\hline $3-3,143-145$ & 5 & & & 3 & 5 & & 2 & & 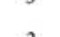 & & & & & & 60 & & 30 & 10 & & 16 & & & & & & 73 & & & 0 & 7 & & 202 & \\
\hline $3-4,70-72$ & ${ }_{2}^{3}$ & & & 5 & & & 4 & & 2 & & & & 3 & & 52 & & 25 & 6 & & 25 & & & & 1 & & 75 & 3 & & 8 & 7 & & 219 & (Upper Oligocene) \\
\hline $\begin{array}{l}3-5,5-7 \\
3-5,143-145\end{array}$ & ${ }_{3}^{2}$ & & & $\begin{array}{l}4 \\
4\end{array}$ & & & ${ }_{7}^{8}$ & & $\begin{array}{l}6 \\
5\end{array}$ & 1 & & & 6 & 10 & 45 & & 17 & ${ }_{7}^{5}$ & & 28 & & & & 4 & 1 & $\begin{array}{l}83 \\
95\end{array}$ & 5 & & 12 & 12 & & 239 & \\
\hline $\begin{array}{l}3-5,6,70-72 \\
3-143\end{array}$ & 6 & & & $\begin{array}{l}4 \\
6\end{array}$ & & & 15 & & $\begin{array}{c}5 \\
12\end{array}$ & 3 & & & $\begin{array}{l}5 \\
3\end{array}$ & $\begin{array}{l}10 \\
36\end{array}$ & $\begin{array}{r}50 \\
5\end{array}$ & & & & 6 & $\begin{array}{l}41 \\
50\end{array}$ & & & & $\begin{array}{l}7 \\
5\end{array}$ & & $\begin{array}{l}95 \\
90\end{array}$ & $\begin{array}{l}17 \\
30\end{array}$ & & $\begin{array}{l}7 \\
18\end{array}$ & $\begin{array}{l}15 \\
27\end{array}$ & & $\begin{array}{l}293 \\
312\end{array}$ & \\
\hline $3-6,85-87$ & 4 & 5 & & 3 & & & 11 & & 10 & 舟 & & & 5 & 40 & 4 & & 15 & 6 & 5 & 32 & & & & 3 & 2 & 85 & 15 & & is & 23 & & 283 & \\
\hline $3-6,126-128$ & 5 & 6 & & 3 & & & 12 & & 7 & & & & 7 & 32 & 2 & & 21 & 5 & 7 & 49 & & & & 2 & 2 & 79 & 9 & & 12 & 20 & & 278 & \\
\hline $4-1,45-47$ & 6 & 4 & & 2 & & & is & & 8 & 2 & 2 & & 4 & 65 & 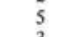 & & & & $i$ & 57 & & & & 6 & & 73 & 14 & & 9 & 31 & 1 & 305 & \\
\hline $\begin{array}{l}4-1,144-146 \\
42,5-7\end{array}$ & 20 & 10 & & 11 & & & 18 & & 8 & 3 & & & 16 & 62 & 3 & & & & 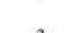 & 64 & & & & & 6 & 48 & 5 & & 14 & 20 & & 305 & \\
\hline $\begin{array}{l}4-2,5-7 \\
4-2,131-133\end{array}$ & $\begin{array}{r}12 \\
8\end{array}$ & $\begin{array}{l}8 \\
7\end{array}$ & & 45 & & & 12 & & $\begin{array}{l}10 \\
16\end{array}$ & 3 & & & & $\begin{array}{l}97 \\
48\end{array}$ & 3 & & 4 & & 3 & $\begin{array}{l}30 \\
43\end{array}$ & & & & 25 & ${ }_{8}^{2}$ & $\begin{array}{l}93 \\
75\end{array}$ & $\begin{array}{l}14 \\
18\end{array}$ & & ${ }_{23}^{24}$ & $\begin{array}{r}18 \\
3\end{array}$ & & $\begin{array}{l}334 \\
321\end{array}$ & \\
\hline $4-3,70-72$ & & & & 4 & & & & & $\begin{array}{r}10 \\
4\end{array}$ & 3 & & & & $\begin{array}{l}40 \\
15\end{array}$ & & & & & & $\begin{array}{l}43 \\
30\end{array}$ & & & & & & 35 & $\begin{array}{r}18 \\
4\end{array}$ & & $\begin{array}{r}23 \\
5\end{array}$ & 14 & & $\begin{array}{l}321 \\
114\end{array}$ & \\
\hline $4-3,145-147$ & 5 & 3 & & 25 & 2 & & 23 & 2 & 7 & 3 & & & 1 & 54 & 4 & & & & 2 & 74 & & & & 12 & 11 & 43. & 8 & 4 & s & 12 & & 321 & \\
\hline $4-4,5-7$ & 4 & & & 29 & & & 4 & & 15 & & & & & 40 & & & & & & 47 & & & & 7 & 7 & 63 & 12 & & 9 & 18 & & 221 & \\
\hline $4-4,147-149$ & & 6 & & 8 & 2 & & & & 6 & 4 & & & & 36 & 1 & & & & & 22 & & & & & 4 & 28 & 12 & & 6 & 10 & & 156 & \\
\hline $\begin{array}{l}4-5,3-5 \\
4-5,145-147\end{array}$ & $\begin{array}{r}17 \\
6\end{array}$ & $\begin{array}{r}4 \\
10\end{array}$ & 1 & 20 & 5 & & 20 & 3 & $\frac{2}{12}$ & $\begin{array}{l}1 \\
6\end{array}$ & & & & $\begin{array}{l}51 \\
53\end{array}$ & 2 & & & & & $\begin{array}{l}63 \\
75\end{array}$ & & & & 25 & 13 & $\begin{array}{l}75 \\
40\end{array}$ & 24 & 5 & 21 & 9 & & \begin{tabular}{|l}
334 \\
334
\end{tabular} & \\
\hline$s-1,9 \cdot 11$ & & & & & & & & & & & & & & & & & & & & & & & & & & & & & & & & & \\
\hline $5-1,147-149$ & 15 & & & 4 & & 2 & 12 & & & 3 & & & & 20 & & & & & & 51 & & & & 6 & 4 & 15 & 49 & & 4 & 5 & & 180 & \\
\hline $\begin{array}{r}5-2,70-72 \\
5-3,65-67 \\
\end{array}$ & $\begin{array}{r}8 \\
12 \\
\end{array}$ & & & $\begin{array}{l}6 \\
6\end{array}$ & & & 3 & & $\begin{array}{l}2 \\
4\end{array}$ & & & & & $\begin{array}{l}10 \\
19\end{array}$ & & & & & & 31 & & & & 4 & 8 & 3 & 24 & & 3 & & & 99 & $\begin{array}{l}\text { Naviculopsis trispinosa } \\
\text { Subzone }\end{array}$ \\
\hline $\begin{array}{l}5-4,29-31 \\
5-5,29-31\end{array}$ & & & & & & & & & & & & & & & & & & & & 35 & & & & 6 & & 4 & 29 & & 2 & & & 120 & $\begin{array}{l}\text { (Upper Eocene) } \\
\text { Barren }\end{array}$ \\
\hline
\end{tabular}


TABLE 8

Distribution of Silicoflagellates, Hole 329

\begin{tabular}{|c|c|c|c|c|c|c|c|c|c|c|c|c|c|c|c|c|c|c|c|c|c|c|}
\hline 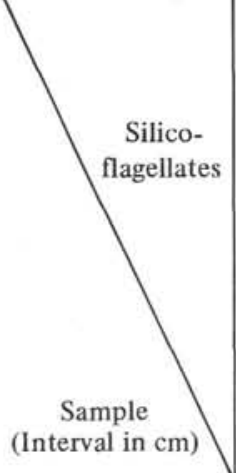 & 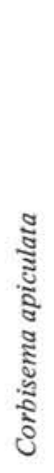 & 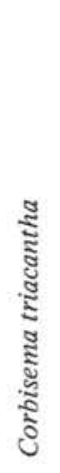 & 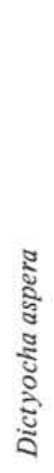 & 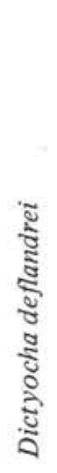 & 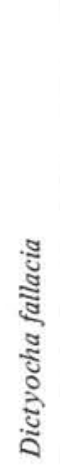 & 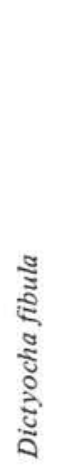 & 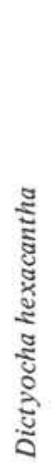 & 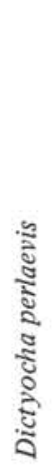 & 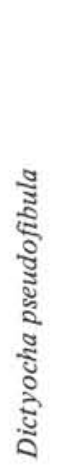 & 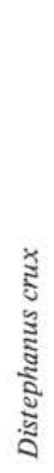 & 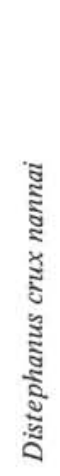 & 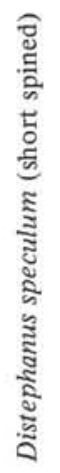 & 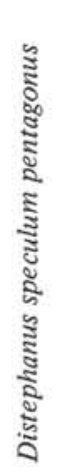 & 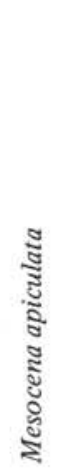 & 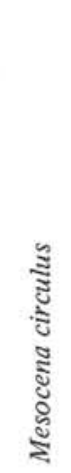 & 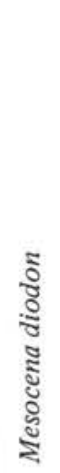 & 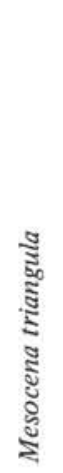 & 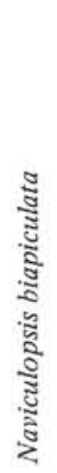 & 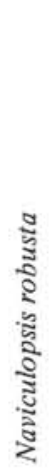 & 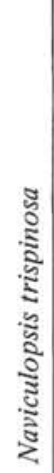 & 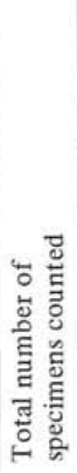 & $\begin{array}{r}\text { Silicoflagellate Zones } \\
\text { (Series or Subseries) }\end{array}$ \\
\hline $\begin{array}{l}1-1,35-37 \\
4-3,30-32 \\
5-1,30-32 \\
6-1,30-32 \\
7-4,30-32 \\
8-3,30-32 \\
9-1,30-32 \\
9-3,114-118 \\
10-4,30-32 \\
12-1,30-32 \\
12-3,30-32 \\
\end{array}$ & & $\begin{array}{l}1 \\
2\end{array}$ & $\begin{array}{l}1 \\
4 \\
3 \\
2\end{array}$ & 1 & & $\begin{array}{l}4 \\
2 \\
2 \\
1\end{array}$ & & & & 2 & & $\begin{array}{l}52 \\
25 \\
17 \\
15 \\
17 \\
23 \\
24 \\
26 \\
32 \\
32 \\
52 \\
\end{array}$ & $\begin{array}{l}3 \\
1\end{array}$ & & $\begin{array}{r}42 \\
23 \\
51 \\
46 \\
85 \\
201 \\
25 \\
20 \\
10 \\
28 \\
19 \\
\end{array}$ & $\begin{array}{r}23 \\
7 \\
14 \\
11 \\
12 \\
20 \\
12 \\
20 \\
14 \\
11 \\
5\end{array}$ & & 1 & & & $\begin{array}{r}119 \\
60 \\
94 \\
78 \\
115 \\
246 \\
61 \\
70 \\
57 \\
76 \\
79 \\
\end{array}$ & $\begin{array}{l}\text { Mesocena circulus/ } \\
\text { Mesocena didon } \\
\text { Zone } \\
\text { (Upper Miocene) }\end{array}$ \\
\hline $\begin{array}{l}13-3,30-32 \\
14-2,30-32 \\
15-5,30-32\end{array}$ & & & $\begin{array}{l}1 \\
P^{4}\end{array}$ & P & & 3 & & & & $\begin{array}{l}5 \\
P\end{array}$ & & $\begin{array}{l}10 \\
19 \\
\mathrm{P}\end{array}$ & 4 & & $\begin{array}{l}8 \\
15 \\
P\end{array}$ & & & & & & $\begin{array}{l}24 \\
45 \\
\mathrm{P}\end{array}$ & $\begin{array}{l}\text { Mesocena circulus Zone } \\
\text { (Middle to upper } \\
\text { Miocene) }\end{array}$ \\
\hline $\begin{array}{l}16-5,30-32 \\
17-2,30-32 \\
17-3,30-32 \\
17-4,30-32 \\
17-6,30-32 \\
18-2,31-33 \\
19-2,30-32 \\
19-4,30-32\end{array}$ & & & & & $\begin{array}{l}9 \\
10 \\
16 \\
30 \\
P\end{array}$ & $\begin{array}{r}15 \\
14 \\
3 \\
18 \\
\mathrm{P}\end{array}$ & & 2 & 1 & $\begin{array}{l}15 \\
18\end{array}$ & $\begin{array}{l}2 \\
P^{2} \\
1\end{array}$ & $\begin{array}{l}\mathrm{P} \\
38 \\
25 \\
23 \\
35 \\
\mathrm{P} \\
48 \\
\mathrm{P}\end{array}$ & $\begin{array}{l}4 \\
3 \\
5 \\
\\
\mathrm{P}^{1}\end{array}$ & & & & & & & & \begin{tabular}{|c|}
$\mathrm{P}$ \\
65 \\
55 \\
62 \\
110 \\
$\mathrm{P}$ \\
52 \\
$\mathrm{P}$ \\
\end{tabular} & (Miocene?) \\
\hline $\begin{array}{l}24-1,138-140 \\
26-1,80-82 \\
26-2,27-29 \\
28-1,5-7 \\
29-1,45-47\end{array}$ & 2 & 2 & & 8 & & 15 & 1 & 1 & & $\begin{array}{l}30 \\
22 \\
10 \\
21 \\
65\end{array}$ & 1 & $\begin{array}{l}11 \\
11\end{array}$ & 3 & $\begin{array}{r}2 \\
8 \\
6 \\
32 \\
43\end{array}$ & $\begin{array}{l}10 \\
19 \\
14\end{array}$ & & 1 & $\begin{array}{r}8 \\
19 \\
61\end{array}$ & $\begin{array}{r}12 \\
1\end{array}$ & $\begin{array}{r}1 \\
6 \\
11\end{array}$ & $\begin{array}{r}73 \\
51 \\
49 \\
90 \\
194\end{array}$ & $\begin{array}{c}\text { Naviculopsis } \\
\text { biapiculata Zone } \\
\\
\text { (Upper Oligocene) }\end{array}$ \\
\hline
\end{tabular}




\section{Corbisema apiculata (Lemmerman)}

(Plate 1, Figures 1, 2)

Dictyocha triacantha var. apiculata Lemmermann, 1901, Deutsch. Bot. Ges., Ber., v. 19, p. 259, pl. 10, fig. 19, 20.

Dictyocha triacantha var. apiculata fa. aspera, Schulz, 1928, Bot. Archiv., v. 21 , no. 2, p. 247-249, fig. 28.

Dictyocha triacantha var. apiculata fa. late-radiata Schulz, 1928, Bot. Archiv., v. 21, no. 2, p. 281, fig. 73.

"Corbisema" apiculata (Lemmermann), Hanna 1931, Mining Calif., v. 27 , no. 2 , p. 198 , pl. D, fig. 2 .

Dictyocha triacantha var. apiculata fa. apiculata Glezer, 1966, In Cryptogamic Plants of the U.S.S.R., p. 229-230, pl. 6, fig. 1.

Corbisema apiculata Ling, 1972, Am. Paleontol. Bull., v. 62, no. 273, p. 153 , pl. 24 , fig. 1 .

Remarks: This species is distinguished by a triangular basal body ring with very short radial spines attached at the corners. Some of the specimens can assume an almost circular form. Although basal accessory spines are considered to be common, many of the Corbisema apiculata in our samples lacked them. This species was most common in the Oligocene sections, but also appeared in small numbers in the upper Paleocene of Hole 327A.

\section{Corbisema archangelskiana (Schulz)}

Dictyocha triacantha var. archangelskiana Schulz, 1928, Bot. Archiv., v. 21 , no. 2 , p. $250-251$, fig. 33 a-c: p. 281 , fig. 77,78 .

Dictyocha triacantha var. archangelskiana Schulz, Gemeinhardt, 1930, in Kryptogamen-Flora, v. 10, pt. 2, p. 45-46, fig. 37a, b. Corbisema archangelskiana (Schulz), Frenguelli, 1940, Rev. Mus., La Plata, v. 2, Paleontol., no. 7, fig. 12a.

Remarks: This species is characterized by three elongated triangular lateral windows, the sides of which are subparallel with narrow but bluntly terminating apices. None of the specimens seen in this study possessed blunt spines on the apices, a feature which has been observed elsewhere.

Few to rare Corbisema archangelskiana were observed in the Paleocene of Hole 327A.

\section{Corbisema bimucronata Deflandre}

$$
\text { (Plate 1, Figure 3) }
$$

Corbisema bimucronata Deflandre, 1950a, Microscopie, v. 2, p. 63/82-64/82, fig. 174-177; Ling, 1972, Am. Paleontol. Bull., v. 62 , no. 273 , p. 153 , pl. 24 , fig. 1

Dictyocha bimucronata Deflandre, Tsumura, 1963, Yokohama

Munic. Univ., Ser. C-45, no. 146, p. 50, pl. 9, fig. 6.

Remarks: This is a small three-windowed species with sharply truncated apices. The specimens seen here do not possess short spines at the edges. Its appearance here is rare and is limited to the upper Paleocene and early Oligocene of Leg 36 cores.

\section{Corbisema cuspis n. sp.}

(Plate 1, Figures 4-6)

Corbisema apiculata (Lemmermann) forma naviculoidea Frenguelli, 1940, Rev. Mus., La Plata, n.s., v. 2, p. 62, fig. $12 \mathrm{i}$ (invalid).

Description: This is a boat-shaped species, bisected by an apical bar. The basal ring is smooth. The apical bar is somewhat narrower than the basal ring and slightly arched. There may be a slight constriction of the basal ring at the juncture of the basal ring and the apical bar. The skeleton is hollow throughout. It possesses no sustaining spines.

Remarks: Although it has the naviculoid form characteristic of the genus Naviculopsis, there is no flattening of any area of the basal ring. It is very similar in overall morphology to the form described as Dictyocha navicula Ehrenberg var. naviculopsis Tsumura (Tsumura, 1963), except that the lumen is absent at both ends of the basal ring in this species. This flattening of the basal ring suggests that the abovementioned species should be reassigned to the genus Naviculopsis. The striking similarity of the two species in all respects except this one could indicate Corbisema cuspis as a precursor of the origin of the genus Naviculopsis from the genus Corbisema. For further discussion see the remarks under Corbisema navicula constricta.

Occurrence: Corbisema cuspis appears in the upper Paleocene of Hole 327A, Falkland Plateau, South Atlantic Ocean.

Measurements: The major axis is $80-120 \mu \mathrm{m}$; the minor axis is $45-$ $55 \mu \mathrm{m}$.
Holotype: Plate 1, Figure 6, USNM 241297

Paratypes: Plate 1, Figures 4, 5, USNM 241295, 241296.

Type locality: Sample $327 \mathrm{~A}-5-1,45-48 \mathrm{~cm}$.

\section{Corbisema geometrica Hanna}

(Plate 1, Figures 7-9)

Dictyocha triacantha var. inermis Lemmermann, 1901, Deutsch Bot. Ges., Ber., v. 19, p. 259, pl. 10, fig. 21.

Corbisema geometrica Hanna, 1928, J. Paleontol., v. 1, no. 4, p. 261, pl. 41, fig. 1, 2; Deflandre, 1940a, C.R. Acad. Sci. Paris, v. 211, no. 19 , p. 446 , fig., 3-4, 6-8; Glezer, 1966, in Cryptogamic Plants of the U.S.S.R., v. 7, pl. 230, pl. 8, fig. 1, 2; pl. 32, fig. 1 .

Dictyocha triacantha var. inermis fa. late-radiata Schulz, 1928, Bot. Archiv., v. 21, no. 2, pl. 281, fig. 74.

Corbisema archangelskiana Stradner, 1961 (not Schulz or Deflandre), Erdol u. Kohle, v. 14, no. 2, pl. 89, fig. 19, 24.

Dictyocha geometrica (Hanna), Tsumura, 1963, Yokohama Munic. Univ., J., Ser. C-45, no. 146, pl. 9, fig. 4, 5; pl. 22, fig. 15, 16. Remarks: The specimens observed were circular to trilobate, with the trilobate forms predominating. Most lacked three apical spines although a few possessing them were seen. Only a few had a triangular apical plate (plate 1, figure 8); generally they had three apical bars with a simple juncture (Plate 1, Figures 7,9). Few to common Corbisema geometrica were observed in the Paleocene, Eocene, and Oligocene of DSDP Leg 36 cores.

\section{Corbisema hastata Lemmermann}

(Plate 2, Figures 1-4, 10; Plate 10, Figures 1, 4)

Dictyocha triacantha var. hastata Lemmermann, 1901, Deutsch. Bot. Ges., Ber., v. 19, p. 259, pl. 10, fig. 16, 17; Frenguelli, 1940, Rev. Mus., La Plata, n.s., v. 2, Paleontol., no. 7, fig. 12c (only). Corbisema hastata Ling, 1972, Am. Paleontol. Bull., v. 62, no. 273, p. 155 , pl. 24 , fig. 5 .

Remarks: The basal ring is more or less an isosceles triangle. The older Paleocene forms display a particular elongation along one axis. The apical apparatus consists of three rods, extending from the approximate mid-point of the basal rods to a simple central apical juncture. In some cases the three lateral rods are slightly skewed from the basal rod mid-points. Three lateral spines extend from each of the three corners of the basal ring, all three spines lying in a plane parallel to each other. The sides of the basal ring are slightly convex at their juncture with the apical rods.

Corbisema hastata is quite abundant in the Paleocene and few to common in the Eocene and Oligocene of Leg 36 cores.

\section{Corbisema inermis inermis (Lemmermann) (Plate 2, Figure 5)}

Dictyocha triacantha var. inermis Lemmerman, 1901, Deutsche. Bot. Gesell. Ver., v. 19, p. 259, pl. 10, fig. 21.

Dictyocha tricantha var. inermis fa. inermis Gleser, 1966, in Cryptogamic Plants of the U.S.S.R., p. 230, pl. 8, fig. 1, 2; pl. 32, fig. 1.

Corbisema inermis (Lemmermann), Dumitrica, Initial Reports of the Deep Sea Drilling Project, v. 21, p. 845-846, pl. 12, fig. 7-9.

Remarks: The basal ring is basically triangular, although there is a wide degree of variability in shape. The apical apparatus consists of three apical bars. The basal ring is thicker than the apical bars. This species is very distinctive because of the thick and highly crenulate appearance of the skeleton. No accessory spines appeared on the specimens seen here. This species occurs only very rarely in the Paleocene.

\section{Corbisema inermis disymmetrica Dumitrica}

(Plate 2, Figure 6)

Dictyocha navicula Lemmermann 1901, Deutsche. Bot. Gessell. Ber., v. 19 , p. 257 , pl. 10 , fig. 11 ; Schulz, 1928 , p. 243 , fig. 16 a; Deflandre, 1932, Soc. France Microsc. Bull., v. 1, fig. 13; Tsumura, 1963, Yokohama Munic. Univ., Ser. C-45, pl. 7, fig. 4; Glezer, 1966, in Cryptogamic Plants of the U.S.S.R., p. 233, pl. 9 , fig. 4,5 .

Corbisema apiculata fa. naviculoidea Frenguelli, 1940, Rev. Mus., La Plata, n.S., v. 2, fig. 121.

Corbisema apiculata var. inermis Deflandre, 1950, Microscopie, fig. 87,88 . 
Corbisema inermis disymmetrica Dumitrica, 1973, Initial Reports of the Deep Sea Drilling Project, v. 21, p. 846, pl. 12, fig. 1-6; pl. 13, fig. 1-8.

Remarks: This species possesses a very robust skeleton and has a large, elliptical basal ring. There may be slight constriction at the juncture of the basal bar with the basal ring. The basal ring is heavy and crenulate. The apical bar is generally thinner and less highly ornamented. There may be sustaining spines. The lumen of the bars is quite narrow. There is a great similarity to Corbisema inermis (Lemmermann) from which it differs because of the generally triangular shape of Corbisema inermis. The basically elliptical shape is rather variable.

Dumitrica's contention that all forms originally described as Dictyocha navicula were actually Corbisema inermis disymmetrica is not entirely correct. Although a great many of the forms so described resembled what Dumitrica called Corbisema inermis disymmetrica certain of these forms were Naviculopsis navicula and many, especially those described by Glezer, are forms referred to as Corbisema navicula navicula and Corbisema navicula constricta in this report. Further discussion of this problem and these forms follows. $327 \mathrm{~A}$

The occurrence of this species is rare in the Paleocene of Hole

\section{Corbisema navicula navicula (Ehrenberg) n. comb.} (Plate 2, Figures 7-9)

Dictyocha navicula (Ehrenberg), Schulz, 1928 (in part), Silicofl., p. 243, fig. 16a; Glezer, 1966 (in part), Cryptogamic Plants of the U.S.S.R., p. 251-252, pl. 9, fig. 4, 5; Tsumura, 1963, J. of Yokohama Munic. Univ., p. 43-44, pl. 7, fig. 4.

Description: Corbisema navicula navicula has an oval to elliptical basal ring, bisected by a narrow apical bar. There may be slight constriction of the basal ring at the juncture with the apical bar. The ends are widely rounded, but are not flattened. This distinction is crucial. Others have observed sustaining spines where the apical bar joins the basal ring, although this was not observed in the specimens studied here. The surface is smooth, only occasionally showing roughness. The skeleton is hollow throughout.

Remarks: This species is not to be confused with Naviculopsis navicula or Corbisema inermis disymmetrica, with both of which it has often been included and placed in synonymy. The confusion arose from the misapplication of Ehrenberg's (1839) initial description) of Dictyocha navicula, which has at various times been considered to include Corbisema inermis disymmetrica, Corbisema navicula navicula, and Naviculopsis navicula. The form Ehrenberg first described in 1839 from Bermuda and again later from Zante, Greece, appears to be the navicular form subsequently assigned to the genus Naviculopsis by Bachmann (1970). Dumitrica (1973) incorrectly stated that Glezer assigned to Dictyocha navicula navicula forms which were actually Corbisema inermis disymmetrica. Although Glezer's description does not necessarily exclude Corbisema inermis disymmetrica, his figures do appear to represent Corbisema navicula navicula. He does not mention the large size or highly crenulate outline associated with Corbisema inermis disymmetrica, features which he could hardly have failed to observe.

Corbisema navicula navicula has been assigned to the genus Corbisema primarily because of the lack of accessory spines on the basal ring other than occasionally at the juncture of the basal ring and the apical bar. As previously mentioned the skeleton is hollow throughout. Since there are no flattened areas on the basal ring of $C$. navicula assignment to the genus Naviculopsis is unjustified. Flattening of the basal ring is characteristic of the genus Naviculopsis (Frenguelli, 1940).

Measurements: The major axis is $50-80 \mu \mathrm{m}$; the minor axis is 30 $35 \mu \mathrm{m}$.

Occurrence: Corbisema navicula navicula is common in the upper Paleocene of Hole 327A. Ciesielski (personal communication) has observed this species in Oligocene material from the Falkland Plateau, differing from the specimens seen in the upper Paleocene only in possessing basal accessory spines. It has been observed previously in upper Paleocene material from Mors and Fuur islands in Denmark, from Western Siberia in the USSR, and from the Southwestern Pacific. The upper Paleocene material from both Denmark and the USSR was originally described as lower Eocene and subsequently reassigned. Some of those upper Paleocene forms did possess the two basal accessory spines.
Corbisema navicula constricta n. subsp.

(Plate 3, Figures 1, 2)

Description: The only substantial difference between Corbisema navicula constricta and Corbisema navicula navicula is the extreme constriction of the basal ring seen in Corbisema navicula constricta. Corbisema navicula navicula may show some stricture but is often, especially in the lower upper Paleocene, almost a perfect oval or ellipse. The ranges of the two species are quite similar, except that more of the highly constricted forms appear later in the upper Paleocene while the elliptical or less constricted forms predominate in the lower part of the upper Paleocene.

Remarks: If, as considered by other authors (Tsumura, 1963; Glezer, 1966), forms now considered to belong to the genus Corbisema were the forerunners of the genera Dictyocha and Naviculopsis, minor differences in morphology may be of major phylogenetic importance. Of special interest in this regard are the forms herein designated Corbisema navicula navicula, Corbisema navicula constric$t a$, and Corbisema cuspis. Deviation from the basically triangular shape of the early Corbisema species may signal the evolutionary departure into the more complex forms soon to appear. Although this is largely conjecture, the importance of delineating any major departures from prior morphological features, in order to obtain detail, should be evident. As more information is gathered, the phylogeny of these species and genera may yet be unraveled.

Measurements: The major axis is $50-80 \mu \mathrm{m}$; the minor axis is 25 $35 \mu \mathrm{m}$.

Occurrence: This species appears commonly in the upper Paleocene of Hole 327A, Falkland Plateau, South Atlantic Ocean.

Holotype: Plate 3, Figure 1, USNM 241298.

Paratype: Plate 3, Figure 2, USNM 241299.

Type locality: DSDP $327 \mathrm{~A}-5-1,45-48 \mathrm{~cm}$.

\section{Corbisema recta Schulz}

Dictyocha triacantha var. recta Schulz, 1928, Bot. Archiv., v. 21, no. 3 , p. 250 , fig. $32 \mathrm{a}$, b.

Phyllodictyocha recta (Schulz), Deflandre, 1946, Soc. Bot. France, Bull., v. 93, no. 9, p. 335-337, fig. a.

Dictyocha recta (Schulz), Tsumura, 1963, Yokohama Munic. Univ., J., Ser. C-45, pl. 9, fig. 2; pl. 22, fig. 8 .

Corbisema recta (Schulz), Ling, 1972, Am. Paleontol. Bull., v. 62, no. 273 , p. 155 , pl. 24 , fig. 6,7

Remarks: This species possesses a slightly convex triangular basal ring with very short radial spines at each corner. The apical structure consists of three lateral rods of equal length. A small apical plate may be present, but was not noted in any of the specimens examined here. Short accessory spines may be present on the abapical side at the corners. Schulz $(1935,1946)$ and Tsumura (1963) describe this species as flattened and lacking a lumen. Ling (1972) found that the specimens he examined did possess a lumen as did the specimens viewed in this study.

Corbisema recta is rarely present in the upper Paleocene and lower Eocene sections of Leg 36 cores.

\section{Corbisema ? sp. Ciesielski}

Corbisema? sp. Ciesielski, 1975, Deep Sea Drilling Project Leg 28, p. 655 , pl. 3 , fig. 7

Remarks: This form possesses a triangular basal ring with three radial spines and an apical apparatus of three lateral rods which form a very small triangular-shaped apical ring. Its strong morphological similarity to and concurrent range with Corbisema triacantha suggest that Corbisema ? sp. may be merely a variation of Corbisema triacantha as suggested by Ciesielski. This form is rare, primarily in the Eocene of Leg 36 cores.

\section{Corbisema triacantha Ehrenberg}

(Plate 3, Figures 3-8)

Dictyocha triacantha Ehrenberg, 1844, Verh. K. Preuss. Acad., Wiss. Berlin, Ber., Jahrg., p. 80

Not Dictyocha triommata Ehrenberg, 1845, Verh. K. Preuss. Akad. Wiss. Berlin, Ber., Jahrg. 1845, p. 56, 76.

Dictyocha trigona Zittel, 1876, Deutsch. Geol. Ges., Zeitschr., v. 28, pl. 83 , pl. 2 , fig. $6,6 \mathrm{a}$.

Corbisema triacantha (Ehrenberg), Ha-na, 1931, Mining in Calif. v. 27, pl. D, fig. 1 . 
Corbisema hastata Frenguelli, 1940, Rev. Mus., La Plata, n.s., v. 2 , Paleontol., no. 7, fig. 12 b.

Dictyocha triacantha fa. minor Desikachary and Mashewari, 1956, Ind. Bot. Soc., Jr., v. 35 , no. 3, p. 258 , text-fig. 2.

Dictyocha triacantha var. triacantha fa. triacantha Glezer, 1966, in Cryptogamic Plants of the U.S.S.R., v. 7, p. 226-227, pl. 4, fig. $1-6$; pl. 5, fig. 1-4.

Corbisema triacantha (Ehrenberg), Mandra, 1968, Calif. Acad. Sci., Proc., ser. 4 , v. 36 , no. 9, p. 249 , fig. $28,21$.

Remarks: This species possesses a triangular basal ring which lies in one plane. It may have a slightly convex outline. Most of the specimens examined here had straight sides. The radial spines extend from the corners. The apical apparatus generally consists of three lateral rods, although a small and underdeveloped apical plate may sometimes be present.

The apical apparatus may be somewhat skewed, a feature which was observed in this study, particularly in the upper Paleocene. These specimens also showed some convexity of the apical structure which constitutes a slight departure from the original description and may provide a basis for future separation of these specimens from Corbisema triacantha proper, probably as a new variety. However, it would seem desirable to do so only with caution as some variability does seem to characterize this species.

Corbisema triacantha is few to common in the Paleocene, Eocene, and Oligocene, and rare to few in the Miocene of Leg 36 cores.

\section{Genus DICTYOCHA Ehrenberg (1839)}

Although this genus was established in 1839 by Ehrenberg, the definition of Dictyocha presently in use is the emended version of Frenguelli (1940) and Deflandre (1950).

The tubular skeleton is composed of a basal ring which is circular, oval, or polygonal. The apical apparatus consists of lateral or lateral and apical rods, or of an apical plate. If supporting spines are present, which is the general case, they appear on the basal ring only and are more or less displaced from the location of the lateral rods.

\section{Dictyocha aspera (Lemmermann)}

(Plate 3, Figure 9)

Dictyocha fibula var. aspera Lemmermann, 1901, Deutsche Bot. Gesell. Ber., v. 19, p. 260, pl. 10, fig. 27, 28.

Dictyocha aspera Bukry and Foster, 1973, Initial Reports of the Deep

Sea Drilling Project, Leg 16, p. 826, pl. 2, fig. 4, 6.

Remarks: Dictyocha aspera is characterized primarily by the parallel alignment of the apical bar with the short axis of the basal ring. The sides are generally gently curved. The four radial spines are short and often of slightly different lengths. There is a certain degree of variability in the length of the apical bar.

Dictyocha aspera in our material is rare to few in the upper Oligocene and appears consistently in the Miocene through Pleistocene material, reaching its greatest abundance in the lower Miocene.

\section{Dictyocha deflandrei (Frenguelli ex Glezer)}

(Plate 3, Figure 10)

Dictyocha deflandrei Frenguelli, 1940, Rev. Mus., La Plata, ser. 2, v. 2 , Paleontol., no. 7 , p. 65 , fig. 14 a-d.

Dictyocha deflandrei Frenguelli ex Glezer, 1966, in Cryptogamic Plants of the U.S.S.R., v. 7, p. 262.

Dictyocha deflandrei completa completa Glezer, 1966, ibid., p. 262, pl. 12 , fig. 14,15 .

Dictyocha deflandrei completa producta Glezer, 1966, ibid., p. 245 , pl. 12, fig. 17-19.

Dictyocha deflandrei deflandrei Glezer, 1966, ibid., p. 244, pl. 12, fig. 13, 16; pl. 32, fig. 4 .

Dictyocha deflandrei Frenguelli ex Glezer, Bukry, 1975b, v. 29, Initial Reports of the Deep Sea Drilling Project, p. 854, pl. 2, fig. 9-13.

Remarks: Although various polygonal basal rings have been noted in this species, only the rhombic forms were observed here. Dictyocha deflandrei has four radial spines of equal length. The apical apparatus is generally an $\mathrm{H}$-shaped plate, differing only from Dictyocha frenguelli in that the struts do not overlap the basal ring.

Dictyocha deflandrei appears consistently but rarely in the upper Eocene to lower Oligocene Leg 36 sediments
Dictyocha fallacia n. sp.

(Plate 4, Figures 2-6)

Description: The basal ring is square to rhombic and possesses straight sides. There are four radial spines which tend to be roughly equal in length although one pair may be somewhat longer than the other. The apical bar is slightly tilted from the plance parallel to the shorter set of radial spines. There are no basal accessory spines.

Measurements: The major axis is $30-45 \mu \mathrm{m}$; the radial spines are 28-34 $\mu \mathrm{m}$.

Remarks: This species differs from Dictyocha aspera var. pygmaea Ciesielski in not possessing basal accessory spines and in not having a high-standing apical bar. Its stratigraphic occurrence also differs. Dictyocha aspera var. pygmaea occurs in the lower Pliocene while Dictyocha fallacia occurs in Oligocene through Miocene sediments.

Occurrence: Oligocene through Miocene.

Holotype: Plate 4, Figure 3, USNM 241031.

Paratypes: Plate 4, Figures 2, 4-6, USNM 241300, 241302241304.

Type locality: Sample $329-18-1,30 \mathrm{~cm}$.

Dictyocha fibula (Ehrenberg)

(Plate 4, Figures 7, 8; Plate 5, Figures 1, 2)

Dictyocha fibula Ehrenberg, 1839, K. Adad. Wiss. Berlin, p. 129.

Remarks: This species is characterized by the parallel alignment of the apical bar with the long axis of the basal ring, a feature which in some cases is difficult to distinguish as the axes may be virtually equal. The outline of the basal ring can be rhomboid or smoothly elliptical with only slight curvature. There is a spine at each of the four corners with those aligned to the long axis somewhat longer.

Dictyocha fibula is present in our Oligocene through Pleistocene material, occurring most commonly in the upper Miocene and lower Pliocene material.

\section{Dictyocha frenguellii (Deflandre)}

Dictyocha fibula Ehrenberg forma frenguellii Deflandre, 1940, C.R. Acad. Sci. Paris, v. 211 , p. 598 , fig. 2.

Dictyoch a frenguellii Deflandre, 1950a, Microscopie, v. 2, p. 194, fig. 188-193.

Dictyocha frenguellii Deflandre frenguellii Glezer, 1966, in Cryptogamic Plants of the U.S.S.R., v. 7, p. 257-258, fig. 9.

Remarks: Dictyocha frenguellii has a small, slightly rounded quadrate basal ring. The apical apparatus consists of a small apical plate whose ends extend outward slightly overlapping the basal ring.

Its appearance is very rare in the upper Eocene and lower Oligocene.

\section{Dictyocha hexacantha (Schulz)}

Dictyocha hexacantha Schulz, 1928, Bot. Archiv., v. 21, no. 2, p. 255 , fig. 43 .

Dictyocha deflandrei fa. hexacantha Frenguelli, 1940, Rev. Mus., La Plata, n. s., v. 2, Paleontol., no. 7, p. 65 , fig. $14 \mathrm{~g}$.

Corbisema hexacantha (Schulz) Deflandre, 1950a, Microscopie, v. 2, p. $65 / 82-66 / 82$, fig. $183-187$.

Dictyocha hexacantha (Schulz) Gelzer, 1966, in Cryptogamic Plants of the U.S.S.R., v. 7, p. 239, pl. 10, fig. 12.

Remarks: The basal ring of this species has a hexagonal form superimposed on a basically triangular outline. Three lateral rods form the apical apparatus. However, the three rods overlap the basal ring and in conjunction with the three basal spines extending from the corners establish the hexagonal shape associated with this species.

Dictyocha hexacantha is rare in the upper Eocene and lower Oligocene of Leg 36 material.

\section{Dictyocha perlaevis (Frenguelli)}

Dictyocha perlaevis Frenguelli, 1951, Physics (Buenos Aires), v. 20, p. 279, fig. 4b, c; Dumitrica, 1973, Initial Reports of the Deep Sea Drilling Project, v, 21 , p. 848,849 , pl. 3, fig. 8-12, pl. 4, fig. $1,2$.

Remarks: This species is characterized by its distinctly lobed appearance, thus separating it from Dictyocha fibula. Dictyocha perlaevis also possesses shorter spines and a more obtuse angle between the apical bar and its struts than Dictyocha fibula.

It is rare in our upper Oligocene through Pleistocene material. 
Dictyocha pseudofibula (Schulz)

(Plate 5, Figures 3, 4)

Distephamus speculum fa. pseudofibula Schulz, 1928, Silicofl., p. 261, 263 , fig. 51a, b.

Dictyocha pseudofibula Tsumura, 1963, Jr. Yokohama Munic. Univ. Ser. C-45, no. 146 , p. 55 , pl. 11 , fig. 1-3; pl. 24, fig. 2.

Remarks: The basal ring of this species is hexagonal. Radial spines extend from each corner, one set of opposing spines somewhat longer than the other four. The apical bar parallels the long axis. Six openings are formed by the apical bar and struts in the center of the basal ring, three large openings and three small openings alternating.

Although windows are present as part of the apical apparatus, these are only considered as part of the strut system supporting the central apical bar, which is why this species is considered a member of the genus Dictyocha rather than the genus Distephanus.

Dictyocha pseudofibula is few to common in the Pliocene and rare to few in the Pleistocene of Leg 36 cores.

\section{Genus DISTEPHANUS Stohr (1880)}

The basal ring of the genus Distephanus is polygonal, possessing from 4 to 11 corners. It differs from the genus Dictyocha primarily in having an apical ring, which is supported by lateral rods. The basal windows thus formed are fairly uniform. As in Dictyocha the sustaining spines in Distephanus appear on the basal ring more or less displaced from the juncture of the lateral rods with the basal ring.

\section{Distephanus boliviensis (Frenguelli)}

Dictyocha boliviensis Frenguelli, 1940, p. 44, fig. 4 (fide Loeblich et al., 1968, p. 83, pl. 9, fig. 3).

Distephanus boliviensis Bukry and Foster, 1973, Initial Reports of the Deep Sea Drilling Project, v. 16, p. 827, pl. 4, fig. 1-3.

Remarks: The basal ring of this species is large. Although it may have six or seven sides, only the six-sided forms were observed here. Basal spines may be present. The radial spines extend from the corners and are all the same length.

Distephanus boliviensis is common to few in the Pliocene.

\section{Distephanus sp. cf. D. boliviensis (Frenguelli)} (Plate 5, Figure 6)

Distephanus sp. cf. D. boliviensis Ciesielski, 1975, Initial Reports of the Deep Sea Drilling Project, v. 28, p. 660, pl. 8, fig. 8; pl. 9, fig. 1, 2 .

Remarks: This species is very similar to Distephanus boliviensis, but the skeleton is much heavier and the microstructure, consisting of subparallel ridges, is much more apparent in Distephanus sp. cf. D. boliviensis.

Ciesielski (1975) did not officially raise Distephanus sp. cf. D. boliviensis to species level, but does list it separately in his charts and does mention it in his taxonomic section.

\section{Distephanus crux crux (Ehrenberg), Haeckel} (Plate 5, Figures 7-11)

Dictyocha crux Ehrenberg, 1840, Monatsberiche, p. 207 (fide Loeblich et al., 1968, p. 85, pl. 8, fig. 29-32).

Dictyocha fibula ? Bailey, 1844, On some new fossil infusoria, p. 139, pl. 3, fig. 16.

Distephanus crux (Ehrenberg) Haeckel, 1887, Radiolaria coll. by Chall, p. 1563.

Remarks: The basal ring is tetragonal or almost circular and has four radial spines projecting from the corners. The apical ring is square to rounded and placed so that its corners, and the supporting struts extending from them, are between the corners of the basal ring.

This species reaches its acme in the upper Oligocene, where it is abundant. As mentioned elsewhere (Ciesielski, 1975; Perch-Nielsen, 1975), there is great vatiation in form. While the normal Distephanus crux crux do appear there are also forms with very large apical windows which fill almost the whole basal ring. There are also forms with one set of quite long radial spines which tend to have very heavy skeletons, the long spines often being crooked. At a future date it may seem advisable to elevate them to a new variety because of their consistent appearance.

This species appears first in the upper Paleocene, occurs commonly in the Eocene, is abundant in the Oligocene, and rarely up into the Pleistocene.
Distephanus crux fenestratus n. subsp.

(Plate 6, Figures 1, 2)

Description: This species has a small tetragonal to rounded basal ring. It is similar to Distephanus crux crux except that it possesses no basal accessory spines and has what appears to be a small square apical plate with a very small circular opening in its middle instead of the simple round apical ring of Distephamus crux crux.

Measurements: The diameter of the basal ring is $35-50 \mu \mathrm{m}$.

Occurrence: Upper Oligocene of Site 328, Malvinas Outer Basin, South Atlantic.

Holotype: Plate 6, Figure 1, USNM 241305.

Paratype: Plate 6, Figure 2, USNM 241306.

Type locality: Sample 328B-3-5, $5-7 \mathrm{~cm}$.

\section{Distephanus crux hannai (Bukry)}

(Plate 6, Figure 3)

?Distephanus crux crux (Ehrenberg) Glezer, 1966, in Cryptogamic Plants of the USSR, v. 7 , p. 279, fig. 14 (5), pl. 18, fig. 3.

?Distephanus crux Ehrenberg, Ling, 1973 (in part), Initial Reports of the Deep Sea Drilling Project, v. 19, pl. 1, fig. 18.

Distephanus crux hannai Bukry, 1975a, Initial Reports of the Deep Sea Drilling Project, v. 29, p. 855, pl. 4, fig. 4-6.

Remarks: The outline of the basal ring is essentially a rounded tetragon and is slightly lobed in outline. The apical ring is quite large. One set of radial spines is somewhat longer, but all four are of moderate length.

This species appears in the Miocene.

\section{Distephanus speculum octonarius (Ehrenberg) Perch-Nielsen}

Dictyocha octonaria Ehrenberg, 1844, Verh. K. Preuss. Akad. Wiss. Berlin, p. 186, 201

Distephanus octonarius (Ehrenberg) Perch-Nielsen, 1975, Initial Reports of the Deep Sea Drilling Project, v. 29, p. 687, pl. 1, fig. 13.

Remarks: Distephanus speculum octonarius differs from Distephanus speculum speculum only in possessing eight sides rather than six. This species appears very rarely in the Pleistocene.

\section{Distephanus polyactis (Ehrenberg) Deflandre, 1932b}

Dictyocha polyactis Ehrenberg, K. Akad. Wiss. Berlin, Abh. 1838, p. 129.

Distephanus polyactis Deflandre, Soc. Bot. France, v. 79, fig. 40, Dumitrica, 1973, Initial Reports of the Deep Sea Drilling Project, p. 851 , pl. 7, fig. 13 ; pl. 8 , fig. 1-10.

Distephanus octonarius var. polyactis Glezer, 1966, in Cryptogamic Plants of the U.S.S.R., v. 7, p. 273 , pl. 21 , fig. $7,8$.

Remarks: The outline of the basal ring is circular. The apical apparatus consists of a very large apical ring which may even overlap the basal ring. The number of radial spines varies from 7 to 14 . There are no accessory spines.

This species occurs sporadically in the upper Pliocene and Pleistocene.

\section{Distephanus speculum speculum (Ehrenberg)}

(Plate 6, Figures 4-7; Plate 10, Figure 2)

Dictyocha speculum Ehrenberg, 1839, Konig. Preuss. Akad. Wiss. Berlin, Ber. Verh., p. 150.

Distephanus speculum (Ehrenberg) Haeckel, 1889, Radiolaria coll. by Chall, p. 1565

Remarks: The basal ring is hexagonal to rounded hexagonal with four radial spines. One set of radial spines is generally somewhat longer than the other, although they can vary from nearly equal in length to having one set a great deal longer than the other four radial spines. There is generally a single apical window supported by six lateral struts, although rarely the window is subdivided.

\section{Distephanus speculum var. septenarius (Ehrenberg)}

Dictyocha septenaria Ehrenberg, 1844, Verh. K. Preuss. Akad. Wiss. Berlin, pl. 21, fig. 18 .

Dictyocha speculum var. septenaria, Hovasse. 1946, Resultats des Campagnes Sci., p. 9.

Distephanus speculum var. septenarius Jorgensen, 1899, Bergens Mus. Arb., p. 50. 
Remarks: Distephanus speculum var. septenarius varies from Distephanus speculum speculum only in possessing seven rather than six sides.

This species occurs very rarely in the Pleistocene.

\section{Genus MESOCENA Ehrenberg, 1843, emend. Deflandre, 1950}

The basal ring is elliptical, triangular, circular, or polygonal. Radial spines either occur in a single row or are absent. There is no apical apparatus, and there are no supporting spines. Lack of septae distinguishes the species of the genus Mesocena from those possessing septae, which are included in the genus Septamesocena.

\section{Mesocena apiculata (Schulz)}

(Plate 7, Figures 1, 5)

Mesocena oamaruensis var. apiculata Schulz, 1928, Bot. Archiv., v. 21 , no. 2 , p. 240 , fig. 11 .

Mesocena polymorpha var. triangula Lemmermann, Gemeinhardt, 1930, Kryptogamen-Flora, v. 10, pt. 2, p. 28, fig. 12a.

Mesocena apiculata Schulz, Hanna, 1931, Mining in Calif., v. 27, no.

2, pl. D, fig. 3; Ling, 1972, Am. Paleontol. Bull., v. 62, no. 273, p. 173 , pl. 28 , fig. $2-4$.

Mesocena aff. apiculata (Schulz), Glezer, 1966, in Cryptogamic Plants of the U.S.S.R., v. 7 , p. 282 , pl. 28 , fig. 5 ; pl. 33, fig. 7.

Remarks: The outline of the basal ring is triangular to roughly triangular. There is a radial spine at each of the three corners.

This species is abundant in the upper Eocene and Oligocene of Leg 36 cores.

Mesocena circulus Ehrenberg

(Plate 7, Figures 2-4, 6; Plate 11, Figures 1, 2)

Dictyocha circulus Ehrenberg, 1840, Verh. K. Preuss. Akad. Wiss. Berlin, Ber., p. 208; Ehrenberg, 1854, Mikrogeologie, pl. 19.

Mesocena circulus Ehrenberg, 1844a, Verh. K. Preuss. Akad. Wiss. Berlin, Ber. P. 65; Tsumura, 1963, Yokohama Munic. Univ., Jr., Ser. C-45, no. 146, pl. 41; Ling, 1972, Am. Paleontol. Bull., v. 62, p. 175,176 , pl. 28 , fig. 5,6 .

Remarks: The basal ring is circular to elliptical and possesses a series of evenly spaced radial spines lying approximately in one plane.

This species is common in the Miocene and rare in the Pliocene and Pleistocene of our cores. Many of the Pliocene and Pleistocene specimens seen were broken and may have been reworked.

\section{Mesocena diodon Ehrenberg}

(Plate 7, Figure 7; Plate 8, Figures 1, 3, 5)

Mesocena diodon Ehrenberg, 1844, p. 71,84 (fide Loeblich et al., 1968 , pp. 54, 128); Ehrenberg, 1854, pl. 33, no 15, fig. 18; Loeblich et al., 1968, pl. 27 , fig. 4 .

Mesocena crenulata var. diodon, Lemmermann, 1901, p. 255, pl. 10, fig. 1, 2; Schulz, 1928, p. 236, fig. 1a, b; Gemeinhardt, 1930, p. 26, fig. 10a; Deflandre, 1932, fig. 4.

Mesocena elliptica diodon, Dumitrica, 1972, p. 905, pl. 1, fig. 3.

Mesocena diodon Dumitrica, 1973, Initial Reports of the Deep Sea

Drilling Project, v. 21, p. 850 , pl. 6, fig. 2 .

Remarks: The circular to elliptical basal ring has two polar radial spines. The surface of the basal ring is almost always heavily ornamented, possessing strong transverse crests.

This species is rare in the middle to upper Miocene of our material.

\section{Mesocena elliptica Ehrenberg}

Mesocena elliptica, Ehrenberg, 1844a, Verh. K. Akad. Wiss. Berlin, p. 71,84 .

Remarks: The outline of the basal ring is basically rhombic but with a high degree of variability. The sides are strongly convex. Generally there are four radial horns but specimens with 2 and 3 have been observed. The radial horns are often of unequal length. The specimens seen here have smooth skeletons.

This species is rare in the upper Pliocene and Pleistocene of our cores.

\section{Mesocena oamaruensis Schulz}

(Plate 8, Figures 2, 6)

Mesocena oamaruensis Schulz, 1928, Bot. Archiv., v. 21, no. 2, p. 240 , fig. $10 \mathrm{a}$, b.
Corbisema oamaruensis (Schulz), Frenguelli, 1940, Rev. Mus., Lat Plata, n. s., v. q, Paleontol., no. 2, p. 64, fig. 13c.

Mesocena oamaruensis Schulz, Tsumura, 1959, Yokohama Munic. Univ., Bull., v. 11, Nat. Sci., no. 1, p. 56, pl. 2, fig. 22.

Remarks: This species possesses a triangular to rounded triangular basal ring lacking radial spines. The surface is smooth.

Mesocena oamaruensis is abundant in the upper Eocene and Oligocene of Leg 36 cores.

\section{Mesocena occidentalis Hanna}

(Plate 8, Figures 4, 7, 8)

Mesocena oamaruensis var. quadrangula Schulz, 1928, Bot. Archiv., p. 240 , fig. $12,13$.

Mesocena occidentalis Hanna, 1931, Mining in Calif., pl. E, fig. 1.

Mesocena quadrangula (Schulz), Tsumura, 1963, Yokohama Munic. Univ., Jr., Ser. C-45, no. 146, p. 42, 43, pl. 7, fig. 3; pl. 21, fig. 11.

Mesocena oamaruensis var. quadrangula Schulz, Ciesielski, 1975, Initial Reports of the Deep Sea Drilling Project, v. 28, p. 661, pl. 12 , fig. 7 .

Remarks: The basal ring is rhombic with a radial spine at each of the four corners. The surface is generally smooth, but there may be surface ornamentation in the form of transverse crests.

This species is common in the upper Eocene and Oligocene of our cores.

Genus NAVICULOPSIS Frenguelli, 1940

The name of this genus is derived from the generally naviculoid, or boat-shaped, outline of the basal ring. The basal ring is bilaterally symmetrical and is bisected by an apical bar. Almost all species possess two polar radial spines. In most species the middle of the basal body ring is flattened at the juncture with the apical bar, frequently showing constriction. In some species the two apices of the major axis are flattened.

\section{Naviculopsis biapiculata (Lemmermann) \\ (Plate 9, Figure 1)}

Dictyocha navicula var. biapiculata Lemmermann, 1901, Deutsch. Bot. Ges., Berlin, v. 19, p. 258 , pl. 10, fig. 14, 15.

Naviculopsis biapiculata (Lemmermann), Frenguelli, 1940, Rev. Mus., La Plata, n., s., v. 2, Paleontol., no. 7, p. 60, fig. 11c, d.

Dictyocha navicula var. apiculata Lemmermann, Tsumura, 1959, Yokohama Munic. Univ., Bull., v. 11, Nat. Sci., no. 1, p. 58, pl. 3, fig. 24-26.

Dictyocha navicula var. biapiculata Lemmermann, Tsumura, 1963, Yokohama Munic. Univ., J., Ser. C-45, no. 146, p. 45, pl. 8, fig. $1-3$; pl. 21, fig. 7-9.

Naviculopsis biapiculata var. biapiculata Glezer, 1966, in Cryptogamic Plants of the U.S.S.R., v. 7, p. 255-256, pl. 16, fig. 2, 4, 5.

Naviculopsis biapiculata (Lemmermann), Ling, 1972, Am. Paleontol. Bull., v. 62 , no. 273 , p. $181-182$, pl. 30 , fig. 1-4.

Remarks: The basal ring is oval in outline and extends into two polar radial spines at a distance equal to or greater than the body length. The skeleton flattens at the juncture of the apical bar with the basal ring and there may be slight constriction. The apical bar is narrow.

This species is common to abundant in the upper Paleocene, Eocene, and Oligocene of our cores.

\section{Naviculopsis constricta (Schulz)}

(Plate 9, Figures 2, 3; Plate 11, Figures 3, 4)

Dictyocha navicula var. biapiculata fa. constricta (Schulz, 1928, Bot. Archiv., v. 21, no. 2, p. 246, fig. 21.

Naviculopsis constricta (Schulz), Frenguelli, 1940, Rev. Mus., La Plata, n. s., v. 2, Paleontol., no. 7, fig. 11a, b.

Naviculopsis biapiculata var. constricta (Schulz), Gelzer, 1966, in Cryptogamic Plants of the U.S.S.R., v. 7, p. 257-258, pl. 17, fig. 4.

Naviculopsis constricta (Schulz), Ling, 1972, Am. Paleontol. Bull., v. 62 , no. 273 , p. $182-183$, pl. 30 , fig. $5-8$.

Remarks: The only significant differences between this species and Naviculopsis biapiculata are that there is a greater amount of constriction of the basal ring where it joins the apical bar and the apical bar is wider than that of Naviculopsis biapiculata, occupying up to a third of the length of the opening within the body ring. 
This species is common in the upper Paleocene, Eocene, and Oligocene of Leg 36 cores.

\section{Naviculopsis foliacea Deflandre}

Naviculopsis foliacea Deflandre, 1950a, Microscopie, v. 2, p. 176182, figs. 235-239.

Remarks: This species differs from Naviculopsis biapiculata and Naviculopsis constricta in possessing a foliated apical bar which occupies more than one-third of the opening within the basal ring. The radial spines also tend to be shorter.

Naviculopsis foliacea is rare in the upper Eocene.

\section{Naviculopsis robusta Deflandre}

(Plate 9, Figures 4-6)

Naviculopsis robusta Deflandre, 1950a, Microscopie, no. 2, p. 74 , fig. $227-230$.

Remarks: The outline of the basal ring is a rounded hexagon, short and broad. The sides of the basal ring are straight or slightly convex. The two polar radial spines are well developed. They are approximately the same length as or somewhat shorter than the length of the body. The skeleton is tubular except for small flat triangular areas between the basal and apical rods. The specimens seen here were smooth.

This species is consistent but few in the Oligocene of our cores.

\section{Naviculopsis trispinosa (Schulz)}

(Plate 9, Figures 7, 8)

Dictyocha navicula var. trispinosa Schulz, 1928, Bot. Archiv., v. 21 , no. 2, p. 246-247, fig. 23a, b.

Naviculopsis biapiculata fa. trispinosa Schulz, Frenguelli, 1940, Rev. Mus., La Plata, n. s., v. 2, Paleontol., no. 7, fig. 11 e.

Dictyocha navicula var. trispinosa Schulz, Tsumura, 1963, Yokohama Munic. Univ., J., Ser. C-45, no. 146 , p. 46 , pl. 8 , fig. 4-6.

Naviculopsis trispinosa (Schulz), Glezer, 1966, in Cryptogamic Plants of the U.S.S.R., v. 7, p. 258-259, pl. 17, fig. 7.

Remarks: This species is differentiated from Naviculopsis biapiculata by possessing a spine projecting from the middle of the apical bar. It is unmistakable in side view.

Naviculopsis trispinosa occurs rarely in the upper Eocene and Oligocene.

\section{Incertae Sedis}

\section{Genus PSEUDOMICROMARSUPIUM, n. gen.}

Description: Pear-shaped basal outline. Apical and abapical arched triangular plates supported by struts. Portions of the skeleton are flattened.

Genotype: Pseudomicromarsupium gombosum, n. sp.

\section{Pseudomicromarsupium gombosum n. sp.} (Plate 12, Figures 1-6)

Description: Most resembles an ebridian, but further SEM study needs to be done to determine whether or not the skeleton is solid throughout.

Basic outline pear-shaped, the tip being flattened. A high arched triangular plate is supported by three thick struts, one such arched plate being present apically and one abapically, and giving a strongly three-dimensional character to the skeleton. The specimen is generally viewed lying so that only one of these arched plates is visible. It was only by finding two specimens which had the plate on one side broken off and one which lay so that a side view was possible that the second arched triangular plate was discerned.

Remarks: Named in honor of Dr. Andrew M. Gombos who discovered this form and pointed it out to one of us (SWW) aboard Glomar Challenger.

Measurements: The major axis is $45-70 \mu \mathrm{m}$.

Occurrence: Upper Paleocene, Falkland Plateau, South Atlantic Ocean.

Holotype: Plate 12, Figures 3-5, USNM 241309.

Paratypes: Plate 12, Figures 1, 2, and 6, USNM 241307 and 241310.

Type locality: Sample 327 A-6-1, $102 \mathrm{~cm}$.

\section{ACKNOWLEDGMENTS}

Although this study began aboard ship where SWW wrote the shipboard report pertaining to silicoflagellates, the bulk of the work including taxonomy was performed on shore by KEB in partial fulfillment of the Masters of Science Degree at Florida State University. We thank Yang-Ja Chung, LaVerne Lamb, and Dennis S. Cassidy for valuable assistance with sample and manuscript preparation. Paul F. Ciesielski provided much helpful discussion on silicoflagellate taxonomy and paleoecology and, along with Menno G. Dinkelman, rendered a critical review of the manuscript. Primary support was provided by an FSU Faculty Research Grant; laboratory facilities were provided by National Science Foundation Grant OPP 74-20109.

\section{NOTE ADDED IN PROOF'}

As this paper was going to press, we learned that a shore laboratory report by David Bukry on DSDP Leg 36 silicoflagellates was being published in the Initial Reports of DSDP Leg 35 (see Bukry, 1976, DSDP Initial Reports Volume 35, p. 885-917). This was done without the knowledge or consent of any member of the DSDP Leg 36 shipboard party, including the Co-chief scientists, the Leg 36 Scientific Editor, or the authors of the present paper. Nevertheless, with the publication of the Bukry article in advance of the present paper by Busen and Wise, the laws of priority set forth in the International Code of Botanical Nomenclature still apply. For that reason, a number of silicoflagellate taxa described in the present paper as new should be placed in synonymy with some described by Bukry. To aid the reader, we list below those forms we consider equivalent as well as one which should be transferred. Corbisema disymmetrica angulata Bukry, $1976=$ Corbisema cuspis Busen and Wise, 1976.

Corbisema disymmetrica communis Bukry, $1976=$ Corbisema navicula navicula Busen and Wise, 1976.

Dictyocha fibula angusta Bukry, $1976=$ Dictyocha fallacia Busen and Wise, 1976.

Distephanus crux darwinii Bukry, $1976=$ Distephanus crux fenestratus Busen and Wise, 1976.

Pseudomicromarsupium falklandensis (Bukry) Busen and Wise, n. comb.

\section{Basionym:}

Corbisema falklandensis Bukry, 1976, Initial Reports of the Deep Sea Drilling Project, v. 35, p. 891, pl. 2, fig. 1-15.

\section{REFERENCES}

Abbott, W.H., Jr., 1972. Vertical and lateral patterns of diatomaceous ooze found between Australia and Antarctica: Ph.D. Dissertation Univ. South Carolina, p. 1-144.

\footnotetext{
'The decision to publish Bukry's Leg 36 silicoflagellate report in Volume 35 was made in order to avoid the creation of a number of nomina nuda in silicoflagellate nomenclature. Because of delays in assembling Volume 36 of the Initial Reports, the names of certain silicoflagellate taxa newly described by Bukry from Leg 36 material would otherwise have first appeared in his report in Volume 38 , which was scheduled to be published before Volume 36. (Ed., DSDP).
} 
Bachmann, A., 1970. Silicoflagellaten aus dem oberosterreichischen Egerien (Oberoligozan): Verh. Geol. B-A., Jahrg., 1970, p. 275-305.

Borgert, A.H.C., 1890. Uber den Bau von Distephanus (Dictyocha) speculum Ehrbg. sp.: Zool. Anz., v. 13, p. $227-$ 231 .

1891. Uber die Dictyochiden, insbesondere uber Distephanus speculum; sowie Studien an Phaeodarien: Z. Wiss. Zool., v. 51, p. 629-676.

Bukry, D., 1973. Coccolith and silicoflagellate stratigraphy DSDP Leg 18, eastern North Pacific. In Kulm, L.D., von Huene, R., et al., Initial Reports of the Deep Sea Drilling Project, Volume 18: Washington (U.S. Government Printing Office), p. 817-831.

1974. Cretaceous and Paleocene coccolith stratigraphy, DSDP Leg 26. In Davies, T.A., Luyendyk, B.P., et al., Initial Reports of the Deep Sea Drilling Project, Volume 28: Washington (U.S. Government Printing Office), p. 669-673.

1975a. Coccolith and silicoflagellate stratigraphy near Antarctica, DSDP Leg 28. In Hayes, D.E., Frakes, L.A., et al., Initial Reports of the Deep Sea Drilling Project, Volume 28: Washington (U.S. Government Printing Office), p. 709-724.

1975b. Coccolith and silicoflagellate stratigraphy, DSDP Leg 29. In Kennett, J.P., Houtz, R.E., et al., Initial Reports of the Deep Sea Drilling Project, Volume 29: Washington (U.S. Government Printing Office), p. 845872.

1975c. Coccolith and silicoflagellate stratigraphy, northwestern Pacific Ocean, DSDP Leg 32. In Larson, R.L., Moberly, R., et al., Initial Reports of the Deep Sea Drilling Project, Volume 32: Washington (U.S. Government Printing Office), p. 677-701.

Bukry D. and Foster, H., 1973. Silicoflagellate and diatom stratigraphy, Leg 16, DSDP. In Winterer, E.L., et al., Initial Reports of the Deep Sea Drilling Project, Volume 16: Washington (U.S. Government Printing Office), p. $815-870$.

1974. Silicoflagellate zonation of upper Cretaceous to lower Miocene deep-sea sediment. J. Res. U.S. Geol. Survey, v. 2, p. 303-310.

Ciesielski, P.F., 1974. Southern Ocean silicoflagellate paleotemperatures based upon Dictyocha to Distephanus ratios: Antarctic J. U.S., v. 9.

, 1975. Biostratigraphy and paleoecology of Neogene and Oligocene silicoflagellates from cores recovered during Antarctic Leg 28, DSDP. In Hayes, D.E., Frakes, L.A., et al., Initial Reports of the Deep Sea Drilling Project, Volume 28: Washington (U.S. Government Printing Office), p. 625-691.

Ciesielski, P.F. and Weaver, F.M., 1973. Southern Ocean Pliocene paleotemperatures based on silicoflagellates from deep-sea cores: Antarctic J. U.S., v. 8, p. 295-297.

Deflandre, G., 1932. Sur la systematique des silicoflagelles: Soc. Bot. France Bull., v. 79, p. 494-506.

1950a. Contribution a l'etude des silicoflagellides actuels et fossiles: Microscopie, v. 2, p. 72-108.

1950b. Contribution a l'etude des silicoflagellides actuels et fossiles: Microscopie, v. 2, p. 117-142.

Donahue, J.G., 1970. Pleistocene diatoms as climatic indicators in North Pacific sediments: Geol. Soc. Am. Mem. 126 , p. $121-138$.

Dumitrica, P., 1973. Paleocene; late Oligocene and postOligocene silicoflagellates in Southwestern Pacific sediments on DSDP Leg 21. In Burns, R.E., Andrews, J.E., et al., Initial Reports of the Deep Sea Drilling Project, Volume 21: Washington (U.S. Government Printing Office), p. 819-883.
Ehrenberg, C.G., 1839. Uber die Bildung der Kreidefelsen und des Kreidemergels durch unsichtbare Organismen: K. Akad. Wiss. Berlin, Abh. 1838, p. 59-148.

1843. Verbreitung und Einfluss des mikroskopischen Lebens in Sud- und Nord-Amerika: Abh. Konig. Akad. Wiss. Berlin, p. 291-445.

Frenguelli, J., 1940. Consideraciones sobre los Silicoflageados fosiles: Extracto de la Revista del Museo de la Plata (Nueva Serie), Seccion Paleontologia, v. 2, p. 37-112.

Gemeinhardt, K. 1930. Silicoflagellatae. In Rabenhorst, L. (Ed.), Kryptogamen-Flora von Deutschland, Osterreich und der Schweiz: Leipzig (Akademische Verlagsgesellschaft), v. 10, pt. 2, p. 1-87.

1931. Organismenformen auf der Grenze zwischen Radiolarien und Flagellaten: Deutsch. Bot. Ges., Ber., v. 49 , p. $103-110$.

1934. Die Silicoflagellaten des Sudatlantischen Ozeans: Wiss. Ergebn. dt. atlant. Exped. "Meteor" $1925-$ 1927. (Biol. Sonderuntersuch.), v. 12, pt. 1, p. 274-312.

Glezer, Z.I., 1966. Silicoflagellatophyceae. In Gollerbakh, M.M. (Ed.), Cryptogamic Plants of the U.S.S.R., V.A. Komarova Bot. Inst. (translated from Russian by Israel Program for Scientific Translations Ltd., Jerusalem, 1970), v. 7, p. $1-363$

Gordon, A.L., 1967. Structure of Antarctic waters between $20^{\circ} \mathrm{W}$ and $170^{\circ} \mathrm{W}$ : Antarctic Map Folio Series, Folio 6.

Hanna, G.D., 1928, Silicoflagellata from the Cretaceous of California: J. Paleontol., v. 1, p. 259-263. 1931. Diatoms and silicoflagellates of the Kreyenhagen shale: Mining in Calif., p. 197-201.

Haeckel, E.H.P.A., 1862. Die Radiolarien (Rhizopoda radiaria.) Eine Monographie: Berlin (Georg Reimer).

1887. Report on the Radiolaria collected by H.M.S. Challenger during the years 1873-1876: Rept. Voy. Challenger, Zool., v. 18, p. 1-1803.

1894. Systematische phylogenie. Entwurf eines Naturlichen Systems der Organismen auf Grund ihrer Stammesgeschichte. Erster Theil: Systematische Phylogenie der Protisten und Pflanzen: Berlin (Georg Reimer), p. 1-400.

Kanaya, T., 1957. Eocene diatom assemblages from the Kellogg and "Sidney" shales, Mt. Diablo Area, California. Sci. Rept. Tohoku Univ. v. 28, p. 1-124.

Kanaya, T. and Koizumi, I., 1966. Interpretation of Diatom Thanatocoenoses from the North Pacific Applied to a Study of Core V20-130 (Studies of a Deep-Sea Core V20130. Part IV): Sci. Rept. Tohoku Univ., v. 37, p. 80-130.

Kutzing, F.T., 1844. Die kieselschaligen Bacillarien oder Diatomeen: Nordhausen, p. 1-152.

Lemmermann, E., 1901. Silicoflagellatae: Deutsche Bot. Ges. Ber., v. 19, p. $247-271$.

Ling, H.Y., 1972. Upper Cretaceous and Cenozoic silicoflagellates and ebridians: Am. Paleontol. Bull., v. 62, p. 133-229.

1973. Silicoflagellates and ebridians from Leg 19. In Creager, J.S., Scholl, D.W., et al., Initial Reports of the Deep Sea Drilling Project, Volume 19: Washington (U.S. Government Printing Office), p. 751-775.

1975. Silicoflagellates and ebridians from Leg 31. In Karig, D.E., Ingle, J.C., Jr., et al., Initial Reports of the Deep Sea Drilling Project, Volume 31: Washington (U.S. Government Printing Office), p. 763-777.

Locker, S., 1974. Revision der silicoflagellaten aus der Mikrogeologischen Sammlung von C.G. Ehrenberg: Eclog. Geol. Helv., v. 67/3, p. 631-653.

Loeblich, A.R., III, Loeblich, L.A., Tappan, H., and Loeblich, A.R., Jr., 1968. Annotated index of fossil and Recent silicoflagellates and ebridians with descriptions of validly proposed taxa: Geol. Soc. Am. Mem. 106, p. 1-319. 
Mandra, Y.T., 1950. Studies on fossil silicoflagellates (Abstract): Geol. Soc. Am. Bull., v. 61, p. 1539. , 1958. Fossil silicoflagellates from California: Ph.D. thesis, Stanford Univ., p. 147. 1960. Fossil silicoflagellates from California, U.S.A.: Copenhagen Int. Geol. Cong., 21 st Sess. Norden, pt. 6, Proc. Sec.6, Pre-Quaternary Micropaleontology, p. 77-89.

, 1968. Silicoflagellates from the Cretaceous, Eocene, and Miocene of California, U.S.A.: Calif. Acad. Sci. Proc., '. 36, p. 231-277.

Mandra, Y.T. and Mandra, H., 1972. Paleoecology and taxonomy of silicoflagellates from an upper Miocene diatomite near San Felipe, Baja California, Mexico: Calif. Acad. Sci. Occas. Papers, no. 99, p. 1-35.

Margolis, S.V. and Kennett, J.P., 1971. Cenozoic paleoglacial history of Antarctica recorded in subantarctic deep-sea cores: Am. J. Sci., v. 271, p. 1-36.

Martini, E., 1971. Neogene silicoflagellates from the equatorial Pacific. In Winterer, E.L., Riedel, W.R., et al., Initial Reports of the Deep Sea Drilling Project, Volume 7: Washington (U.S. Government Printing Office), p. 1695-

Muller, J., 1856. Uber die Thalassicollen, Polycystinen und Acanthometren des Mittelmeeres: Mber. Verh. K. Preuss. Akad. Wiss. Berlin, p. 474-503.

Perch-Nielsen, K., 1975. Late Cretaceous to Pleistocene silicoflagellates from the southern southwest Pacific, Leg 36. In Kennett, J.P., Houtz, R.E., et al., Initial Reports of the Deep Sea Drilling Project, Volume 29: Washington (U.S. Government Printing Office), p. 677-721.

Poelchau, H.S., 1974. Holocene silicoflagellates of the North Pacific: Their distribution and use for paleotemperature analysis: Ph.D. dissertation, Univ. of Calif., San Diego.

Proshkina-Lavrenko, A.I., 1959. Sovremennye i iskopaemye silikoflagellaty i ebriidei Chernomorskogo basseyna.
Silicoflagellatae nec non ebriideae nostrorum temporum et fossiles ponti euxini: Akad. Nauk SSR, Tr. Bot. Inst., ser. 2, Sporovye Rasteniya, vyp. 12, p. 142-175.

Sanfilippo, A., Burckle, L.H., Martini, E., and Riedel, W.R., 1973. Radiolarians, diatoms, silicoflagellates and calcareous nannofossils in the Mediterranean Neogene: Micropaleontology, v. 19, p. 209-234.

Savin, S.M., Douglas, R.C., and Stehli, F.G., 1975. Tertiary marine paleotemperatures: Geol. Soc. Am. Bull., v. 86, p. $1499-1510$.

Schulz, P., 1928. Beitrage zur Kenntnis fossiler and rezenter Silicoflagellaten: Bot. Archiv., v. 21, p. 225-292.

Stohr, E., 1880. Die Radiolarienfauna der Tripoli von Grotte, Provinz Girgenti in Sicillen: Paleontographica, v. 26, p. 69-124.

Stradner, H., 1961. Uber fossile Silicoflagelliden und die Moglichkeit ihrer Verwendung in der Erdolstratigraphie: Erdol und Kohle, v. 14, p. 87-92.

Tsumura, K., 1959. Komentaritta figuraro de Silikoflageluloj: Yokohama Municipal Univ. Bull., v. 11, Nat. Sci. v. 1, p. 35-90.

1963. A systematic study of Silicoflagellatae. Hour. Yokohama Municipal Univ., Ser. C-45, v. 146, p. 1-84.

Van Valkenburg, S.D. and Norris, R.E., 1970. The growth and morphology of the silicoflagellate Dictyocha fibula Ehrenberg in culture: J. Phycology, v. 6, no. 48.

Weaver, F.M., 1973. Pliocene paleoclimatic and paleoglacial history of East Antarctica recorded in deep sea piston cores: Sedimentol. Res. Lab., Dept. of Geol., Florida State Univ., Contribution 36.

Weaver, F. M. and Ciesielski, P. F., 1973. Pliocene paleoclimatic history recorded in Antarctic deep sea cores: Geol. Soc. Am., Abstracts with Programs, p. 856-857. 


\section{PLATE 1}

(All specimens $2800 \times$ )

Figures 1, 2 Corbisema apiculata (Lemmermann).

1. Sample $327 \mathrm{~A}-7-2,45-47 \mathrm{~cm}$.

2. Sample 327 A-5-1, $45-48 \mathrm{~cm}$.

Figure 3 Corbisema bimucronata Deflandre, Sample 327A$5-1,45-48 \mathrm{~cm}$.

Figures 4-6 Corbisema cuspis $\mathrm{n}$. sp.

4. Paratype USNM 241295, Sample 327A-6-3, $109-111 \mathrm{~cm}$.

5. Paratype USNM 241296, Sample 327A-7-2, $146-148 \mathrm{~cm}$.

6. Holotype USNM 241297, Sample 327A-5-1, $45-48 \mathrm{~cm}$.

Figures 7-9 Corbisema geometrica Hanna.

7. Sample $327 \mathrm{~A}-5-1,45-48 \mathrm{~cm}$.

8. Sample 327A-6-2, 146-148 cm.

9. Sample $327 \mathrm{~A}-7-2,45-47 \mathrm{~cm}$. 
PLATE 1

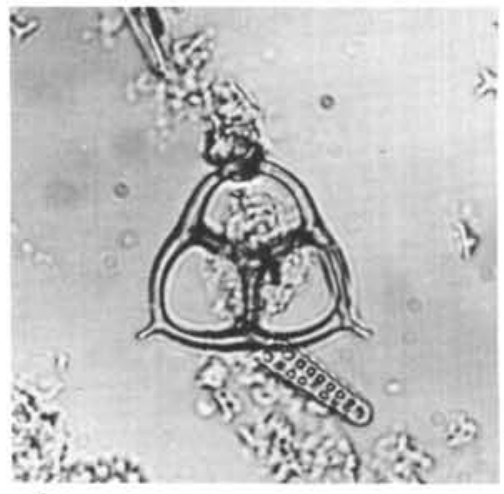

1

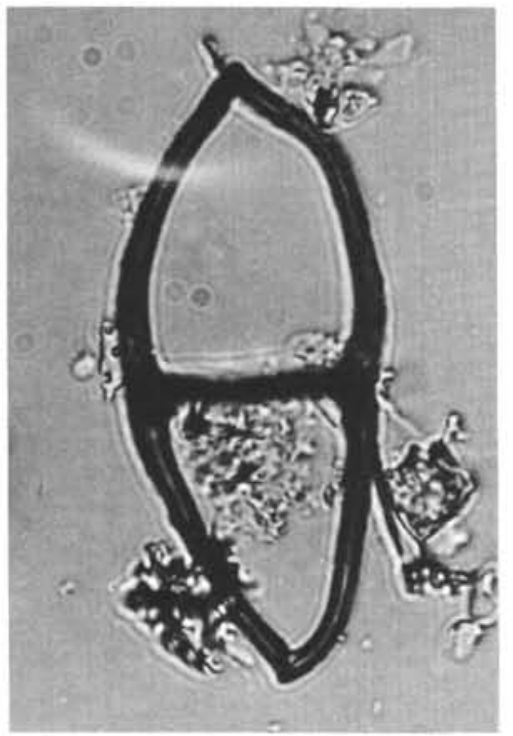

4

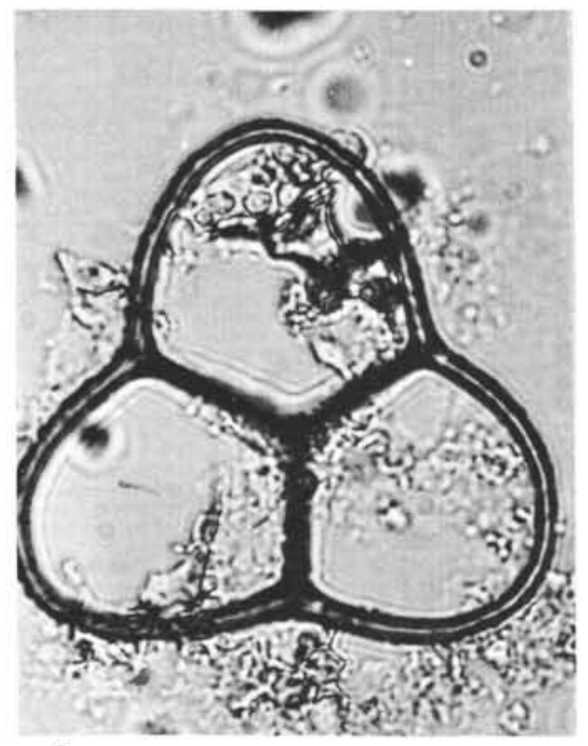

7

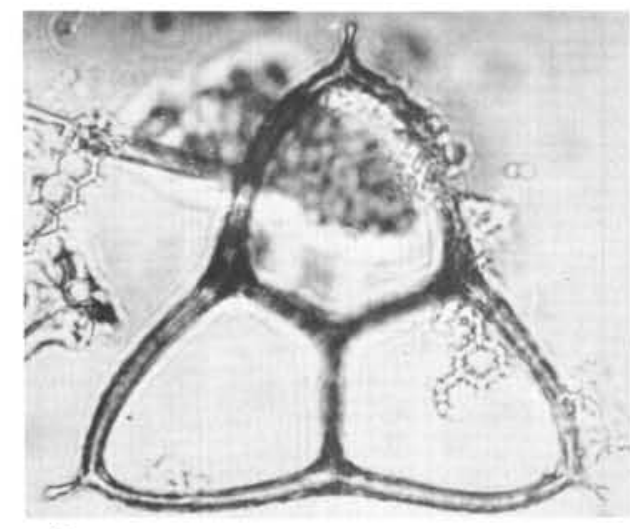

2

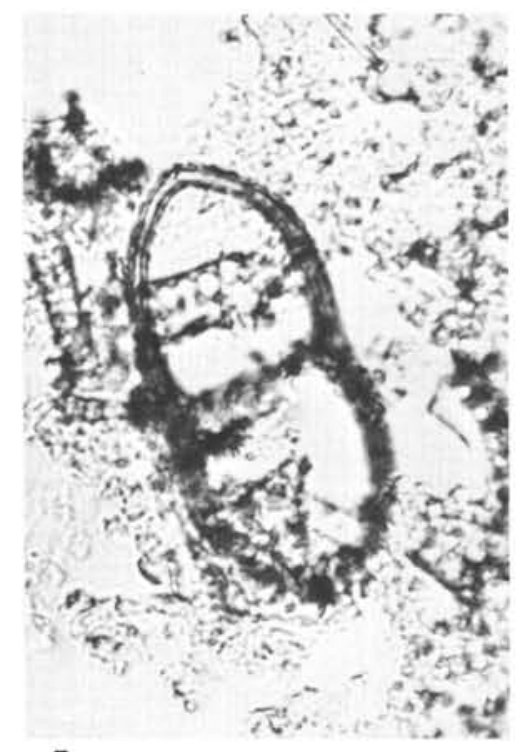

5

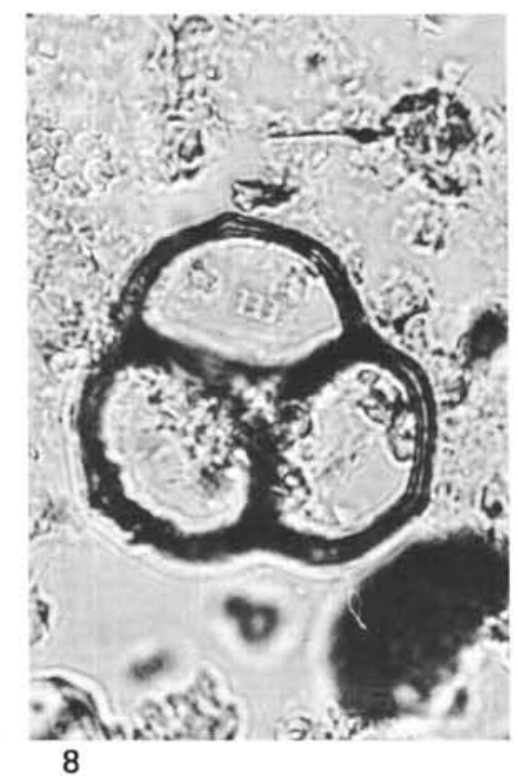

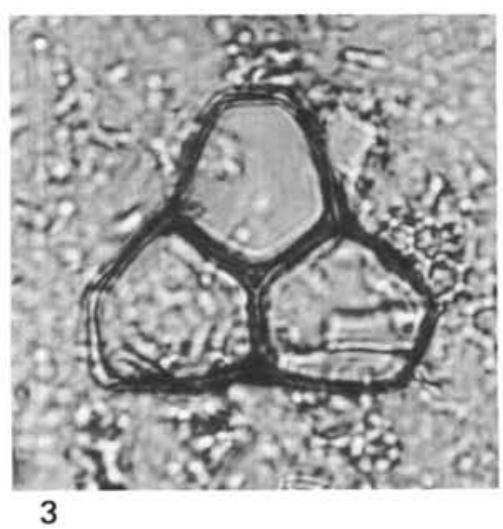

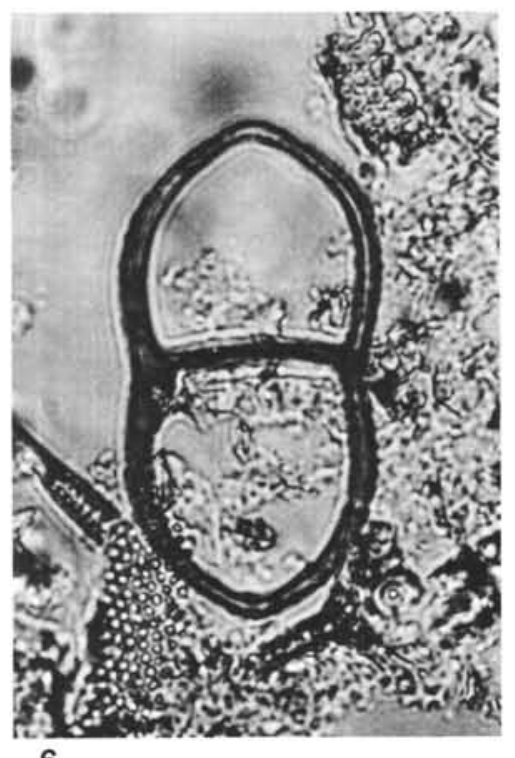

6

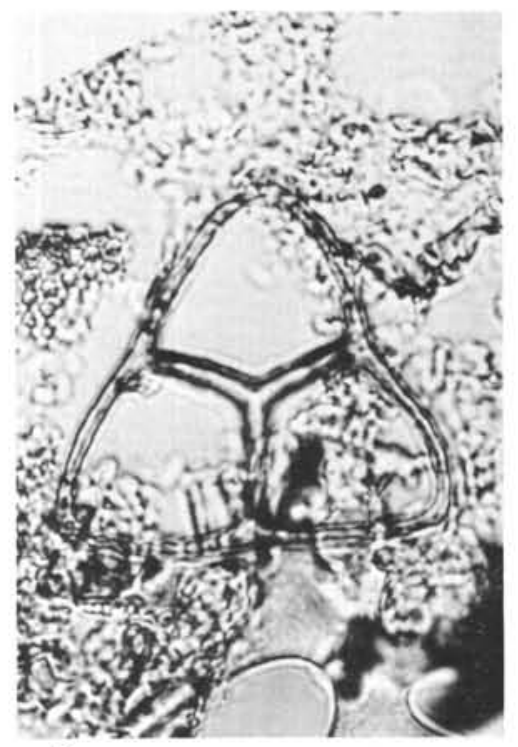

9 
PLATE 2

(All specimens $2800 \times$ )

Figures 1-4, 10 Corbisema hastata Lemmermann.

1. Sample 327A-5-1, $45-48 \mathrm{~cm}$.

2. Sample $327 \mathrm{~A}-7-2,45-47 \mathrm{~cm}$.

3. Sample 327A-7-2, 146-148 cm.

4. Sample 327A-7-2, $146-148 \mathrm{~cm}$.

10. Sample 327 A $-5-1,45-48 \mathrm{~cm}$.

Figure 5 Corbisema inermis inermis Lemmermann, Sample $327 \mathrm{~A}-7-2,146-148 \mathrm{~cm}$.

Figures 7-9 Corbisema navicula navicula, n. comb.

7. Sample $327 \mathrm{~A}-5-1,45-48 \mathrm{~cm}$.

8. Sample $327 \mathrm{~A}-7-2,45-48 \mathrm{~cm}$.

9. Sample 327A-7-2, 146-148 cm. 


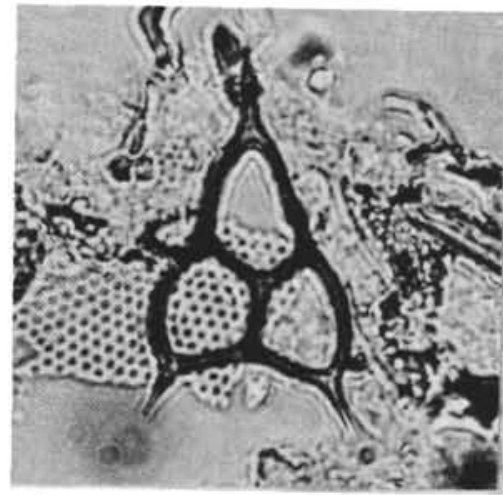

1
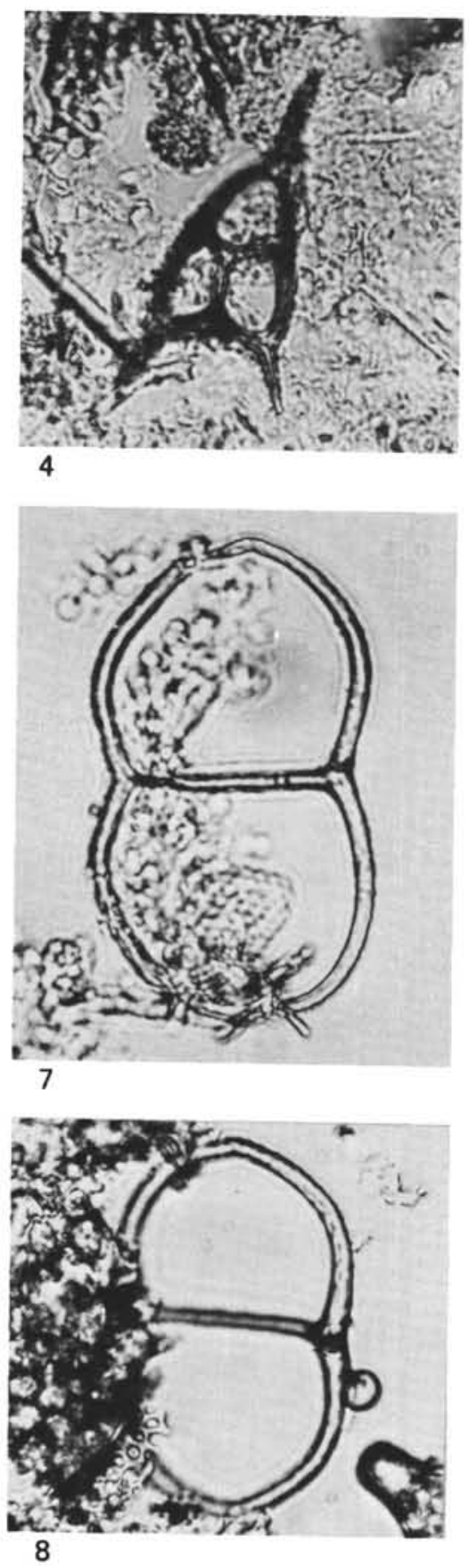

PLATE 2
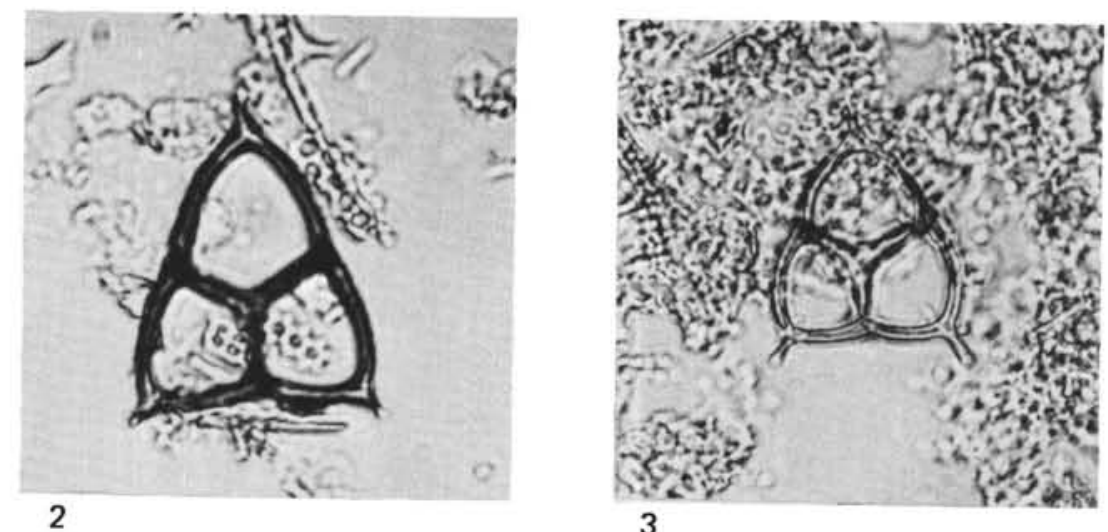

3

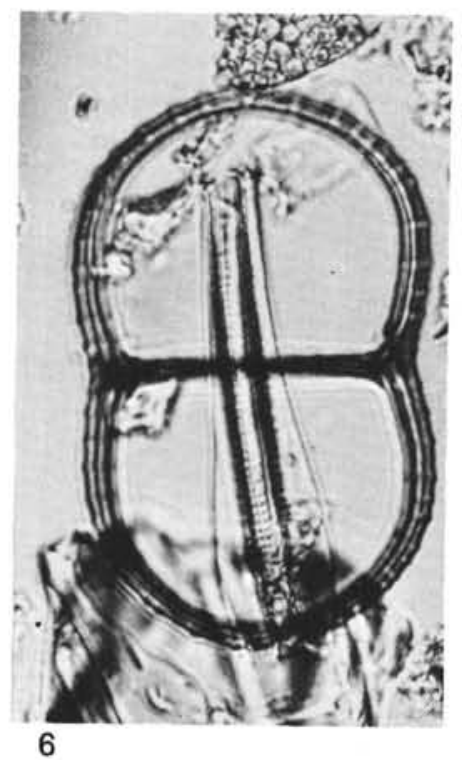

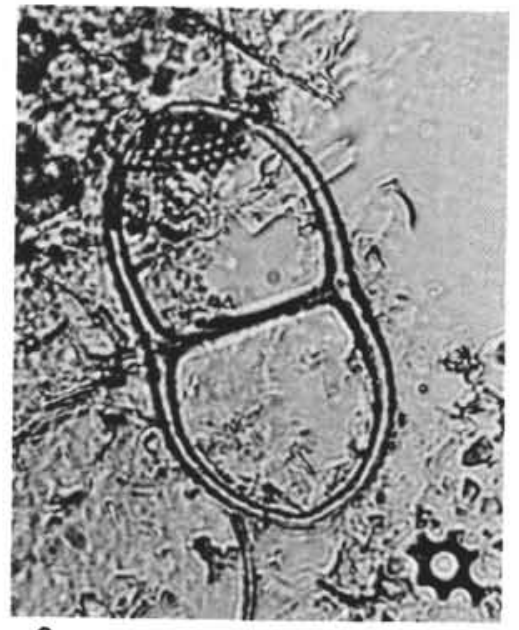

9
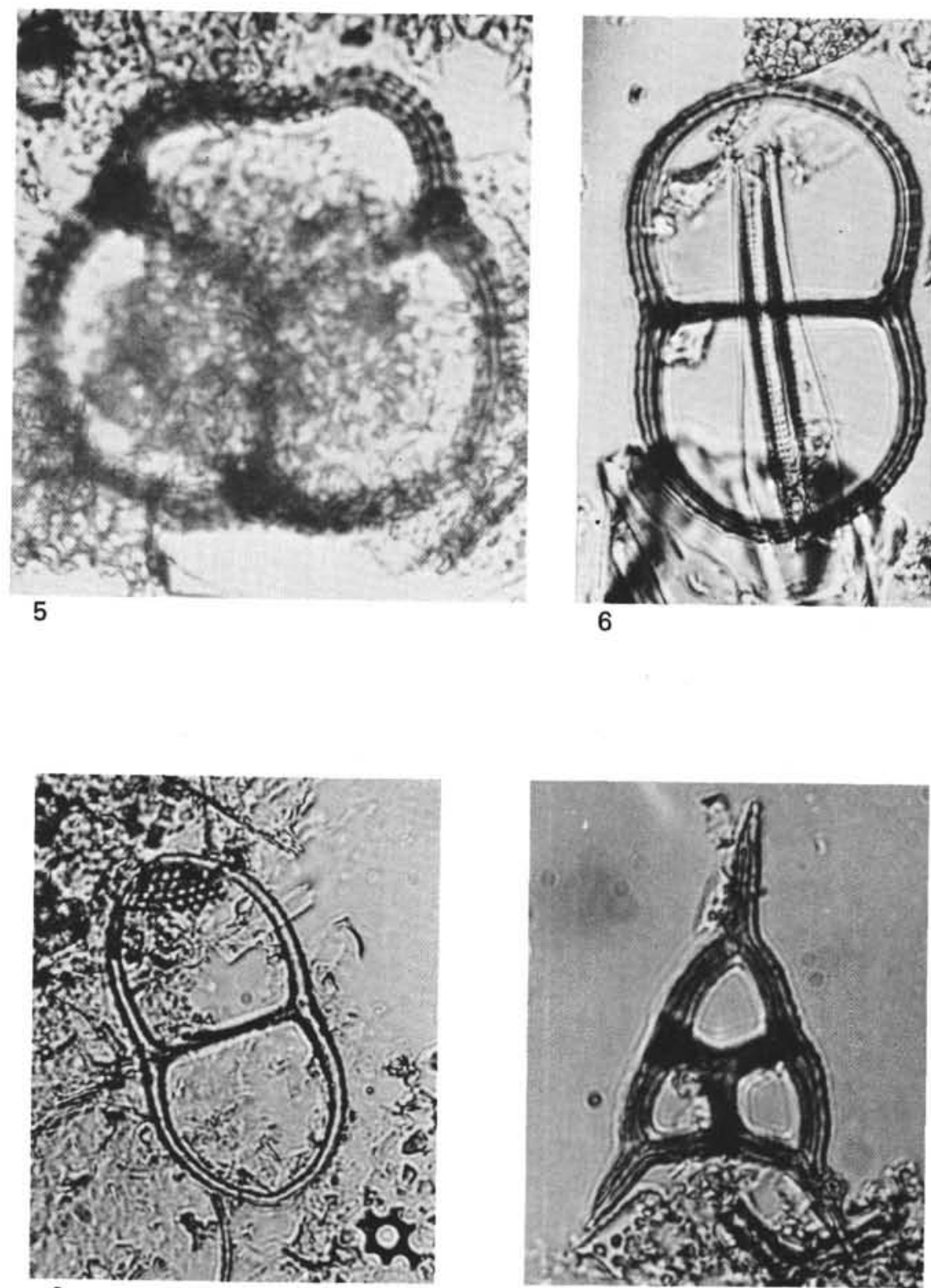

10 


\section{PLATE 3}

(All specimens $2800 \times$ )

Figures 1, 2 Corbisema navicula constricta, n. sp.

1. Holotype USNM 241298, Sample 327A-5-1, $45-48 \mathrm{~cm}$.

2. Paratype USNM 41299, Sample 327A-5-1, 45$48 \mathrm{~cm}$.

Figures 3-8 Corbisema triacantha Ehrenberg.

3. Sample 329-29-1, $45-47 \mathrm{~cm}$.

4. Sample 329-29-1, $45-47 \mathrm{~cm}$.

5. Sample 327A-5-1, $45-48 \mathrm{~cm}$.

6. Sample $327 \mathrm{~A}-7-2,45-48 \mathrm{~cm}$.

7. Sample $327 \mathrm{~A}-7-2,45-48 \mathrm{~cm}$.

8. Sample 327A-7-2, $146-148 \mathrm{~cm}$.

Figure 9 Dictyocha aspera (Lemmermann), Sample 328B-1$6,70-72 \mathrm{~cm}$.

Figure 10 Dictyocha deflandrei (Frenguelli ex Glezer), Sample 329-29-1, 45-47 cm. 
PLATE 3
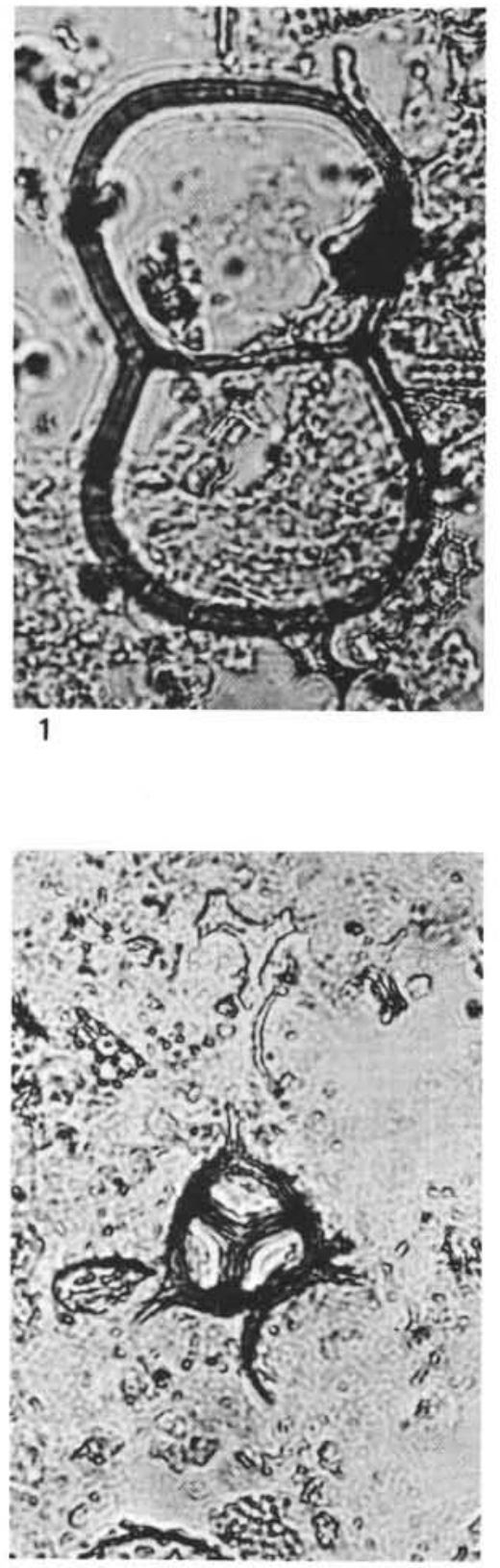

4

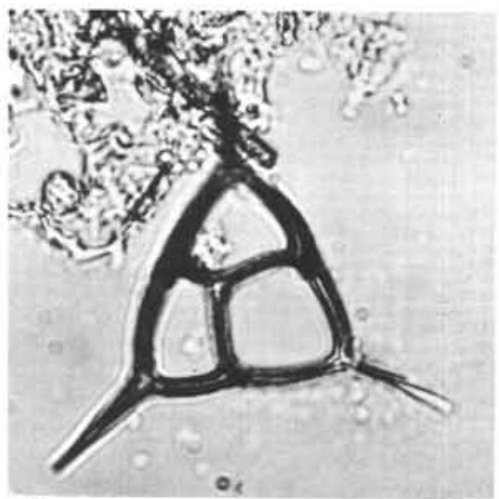

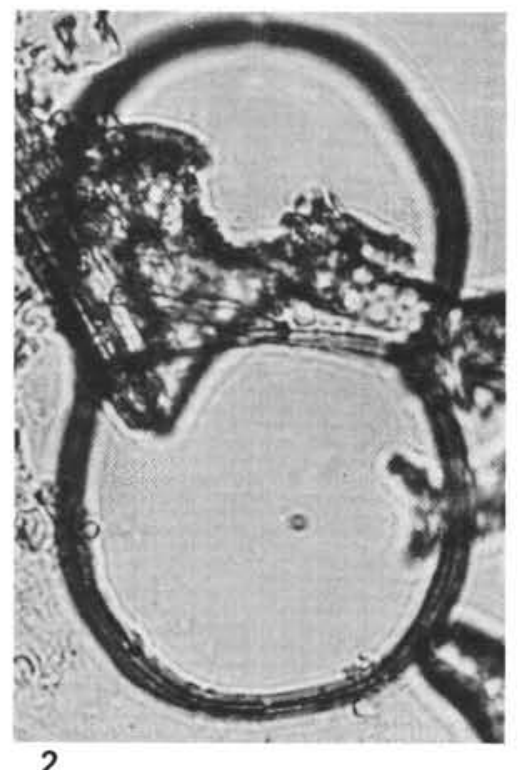
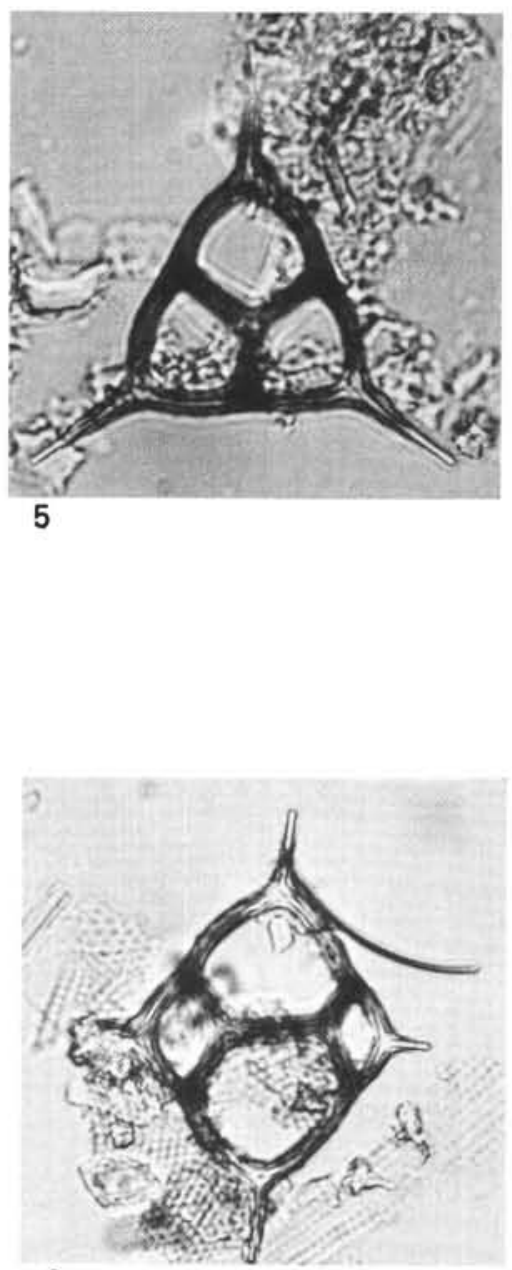


7

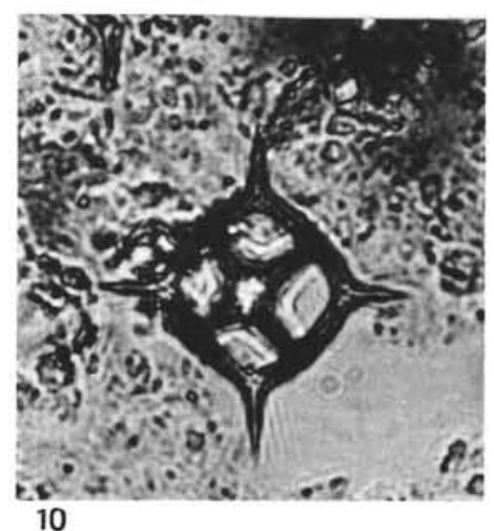


PLATE 4

(All specimens $2800 \times$ except Figure 4 which is $3400 \times$ )

Figure 1 Dicțocha deflandrei (Frenguelli ex Glezer), Sample $328 \mathrm{~B}-3-5,5-7 \mathrm{~cm}$.

Figures 2-6 Dictyocha fallacia $\mathrm{n}$. sp.

2. Paratype USNM 241300, Sample 329-18-1, 30$32 \mathrm{~cm}$.

3. Holotype USNM 241301, Sample 329-18-1, 30$32 \mathrm{~cm}$.

4. Paratype USNM 241302, Sample 328B-4-5, $145-147 \mathrm{~cm}$.

5. Paratype USNM 241303, Sample 328B-4-3, $145-147 \mathrm{~cm}$.

6. Paratype USNM 241304, Sample 328B-4-3, $145-147 \mathrm{~cm}$.

Figures 7,8 Dictyocha fibula Ehrenberg.

7. Sample 327 A-7-2, $45-47 \mathrm{~cm}$.

8. Sample 328B-1-6, $70-72 \mathrm{~cm}$. 
PLATE 4
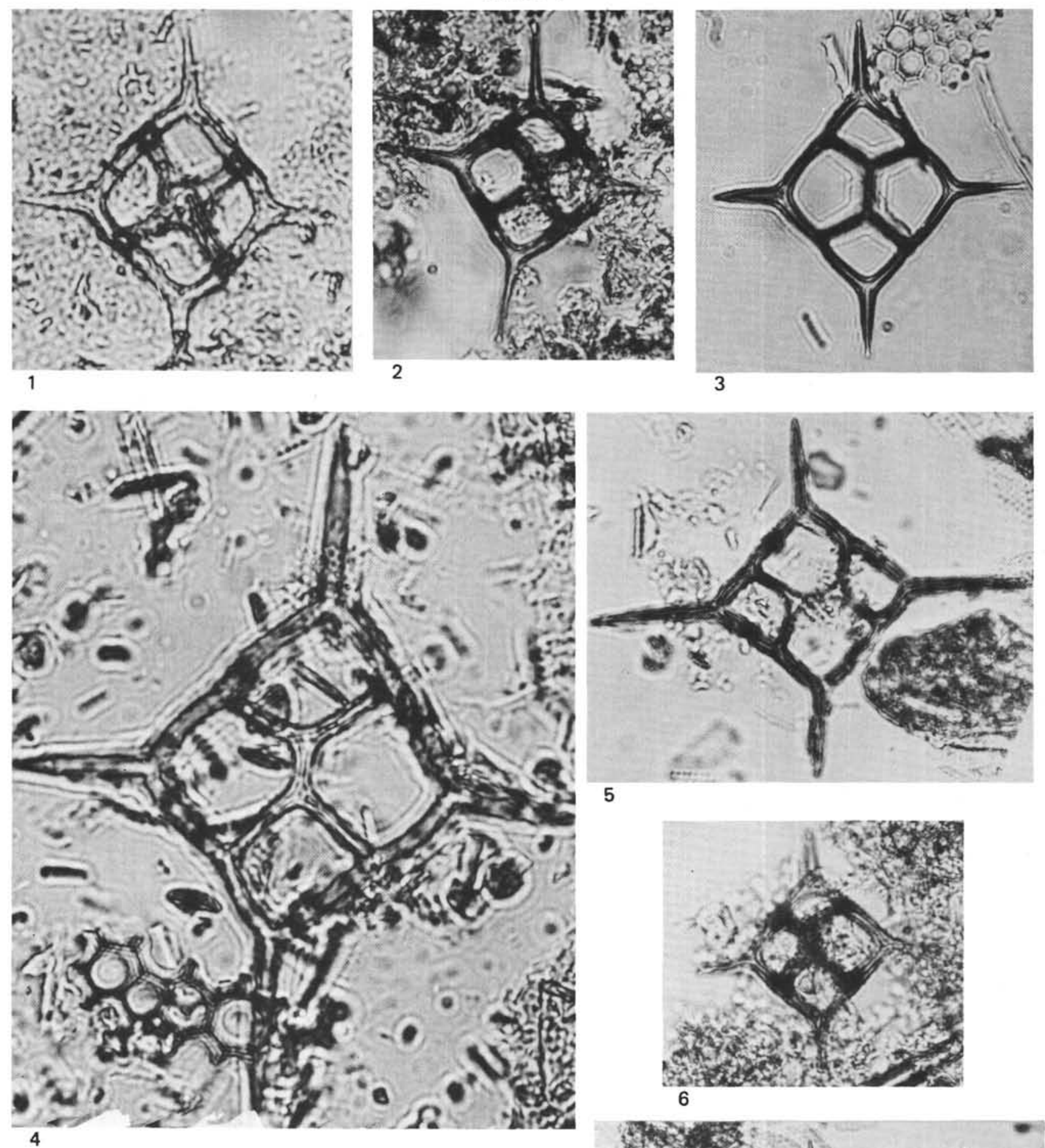

\section{5}
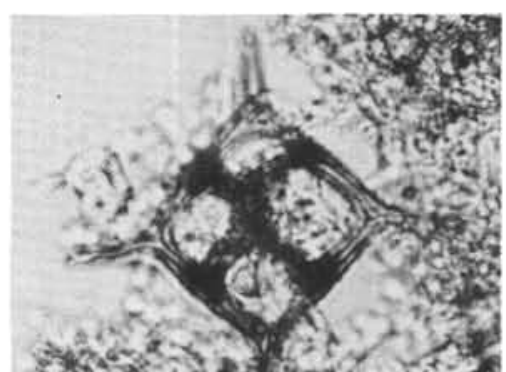
(5)

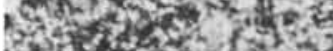

\section{6}

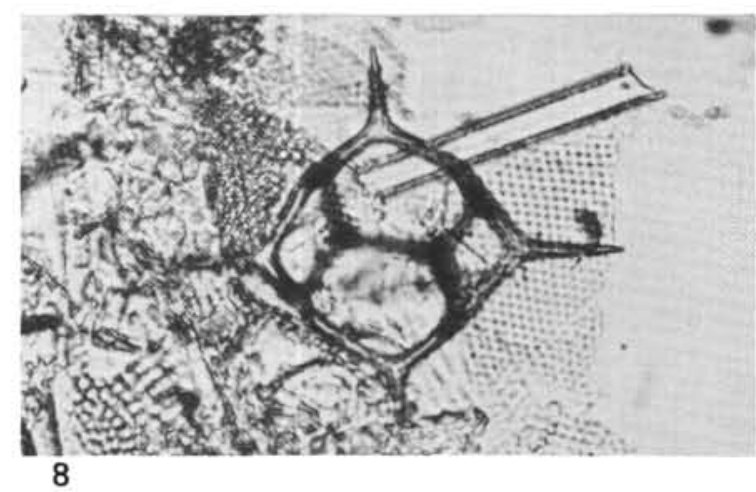




\section{PLATE 5}

(Specimens 2800 except Figures 2, 9, and 11 which are $3400 \times$ )

Figures 1,2 Dictyocha fibula Ehrenberg.

1. Sample 328B-1-4, 5-7 cm.

2. Sample 328B-1-6, 140-142 cm.

Figures 3, 4 Dictyocha pseudofibula (Schulz).

3. Sample 328B-1-5, 147-149 cm.

4. Sample 328B-1-5, 147-149 cm.

Figure 5 Dictyocha sp., Sample 328B-1-6, 140-142 cm.

Figure 6 Dictyocha sp. cf. D. boliviensis (Frenguelli), Sample $328 \mathrm{~B}-1-5,5-7 \mathrm{~cm}$.

Figures 7-11 Distephanus crux (Ehrenberg).

7. Sample 328B-1-5, 5-7 cm.

8. Sample 328B-1-5, 5-7 cm.

9. Sample 328B-2-1, $144-146 \mathrm{~cm}$.

10. Sample $328 \mathrm{~B}-4-5,3-5 \mathrm{~cm}$.

11. Sample $328 \mathrm{~B}-4-5,3-5 \mathrm{~cm}$. 
PLATE 5
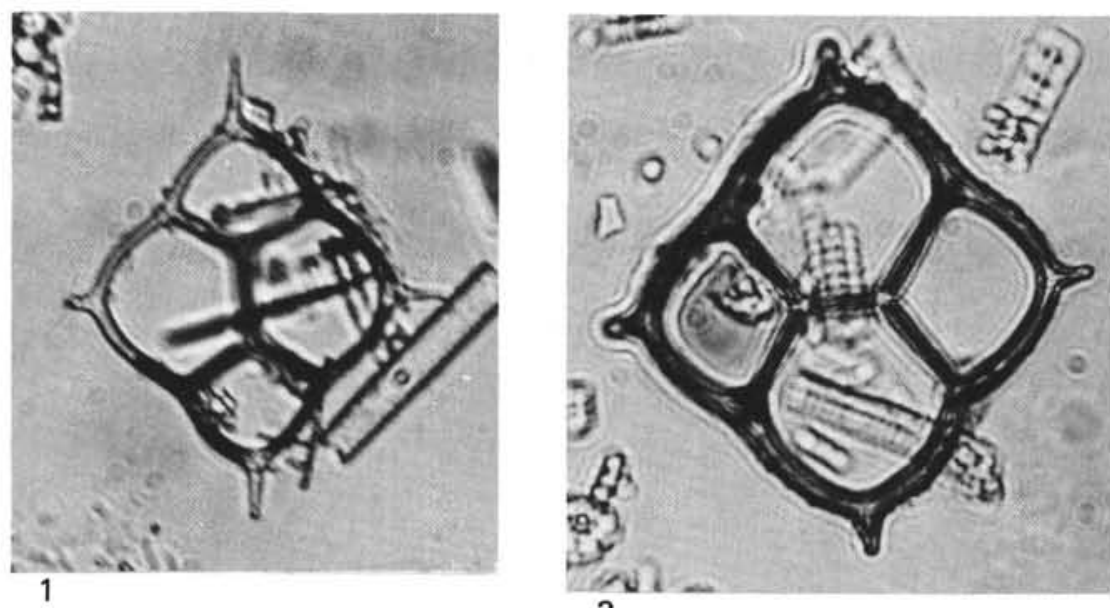

2

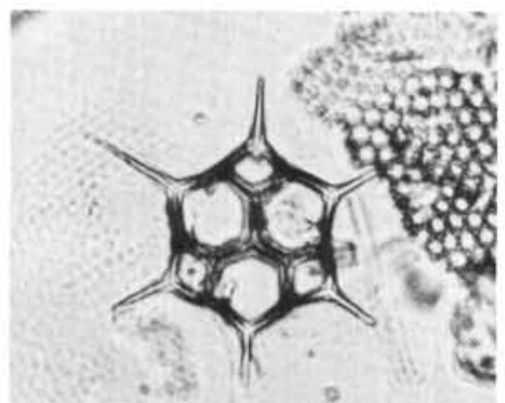

4

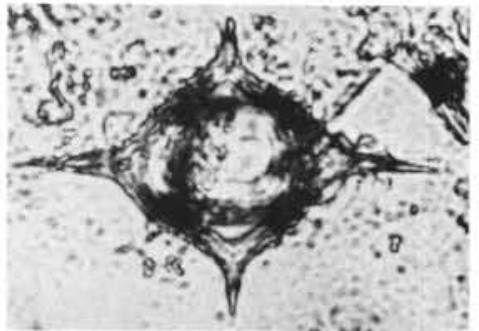

7

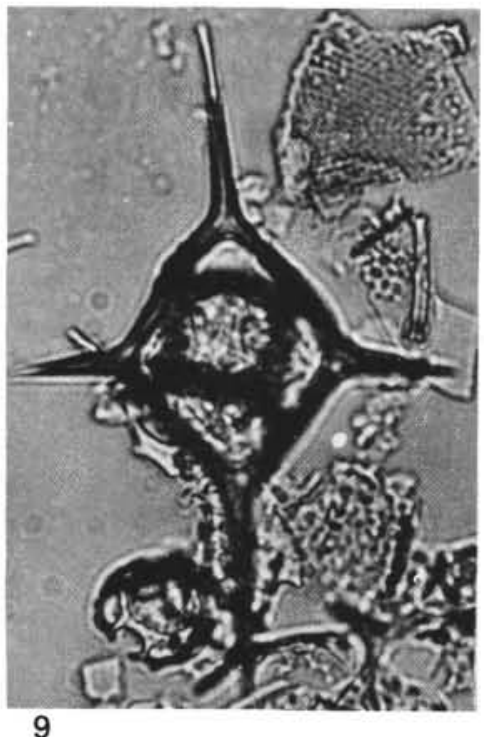

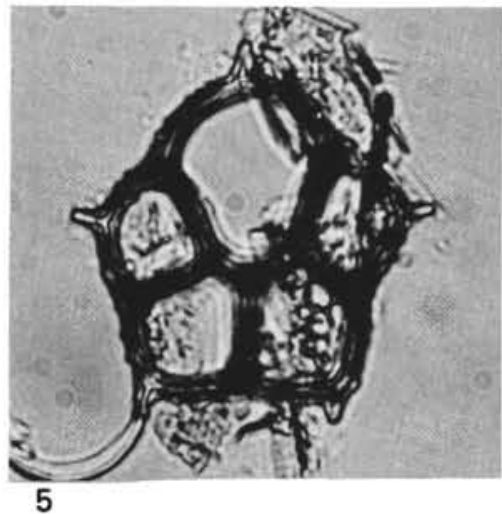

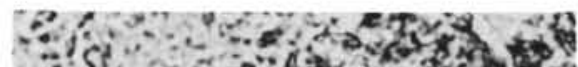

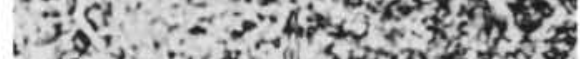

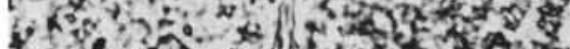

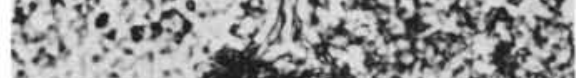
5 (15) 8

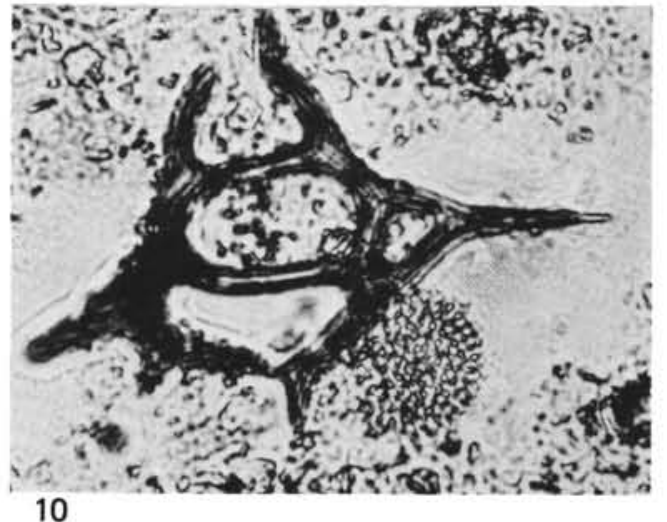

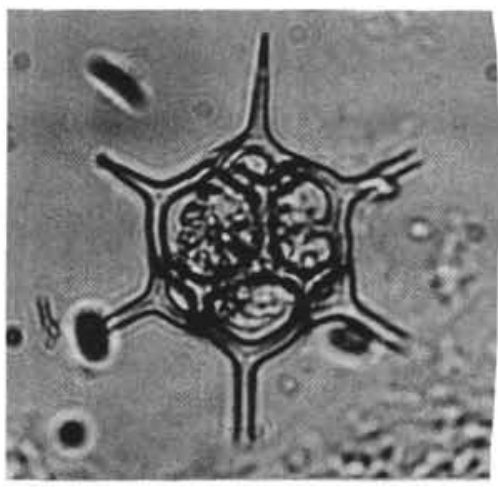

3

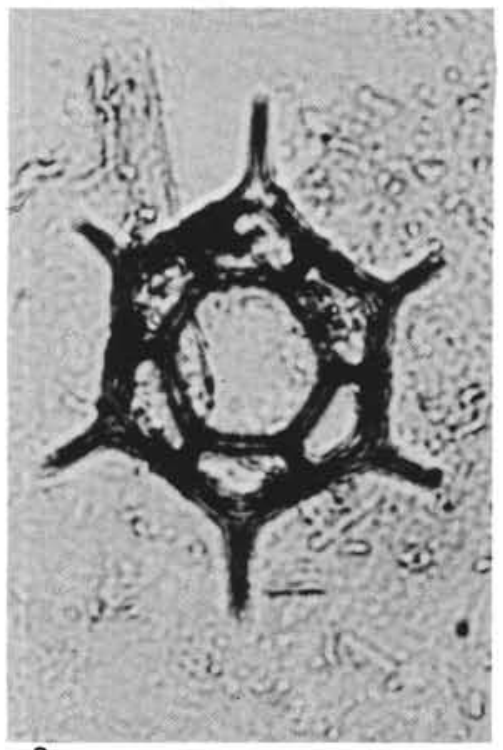

6

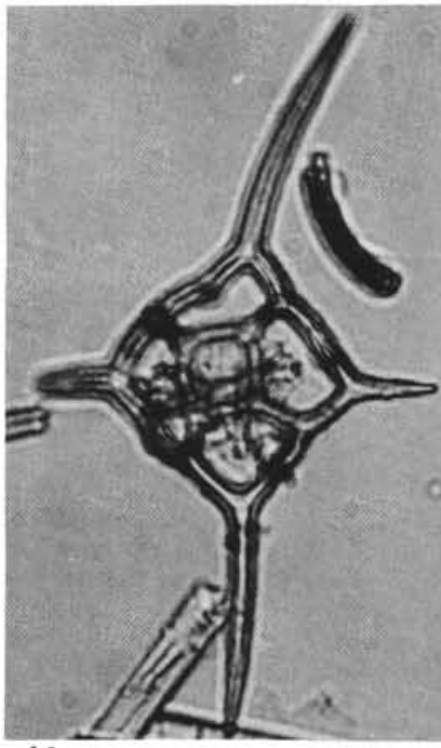


K. E. BUSEN, S. W. WISE, JR.

\section{PLATE 6}

(All specimens $2800 \times$ except Figure 10 which is $3400 \times$ )

Figures 1,2 Distephanus crux fenestratus n. subsp.

1. Holotype USNM 241305, Sample 328B-3-5, 5-7 $\mathrm{cm}$.

2. Paratype USNM 241306, Sample 328B-3-5, 5-7 $\mathrm{cm}$.

Figure 3 Distephanus crux hannai Bukry, Sample 328B-3-1, $145-147 \mathrm{~cm}$.

Figures 4-7 Distephanus speculum speculum (Ehrenberg).

4. Sample 328B-1-4, 5-7 cm.

5. Sample 328B-1-6, 140-142 cm.

6. Sample $328 \mathrm{~B}-2-1,5-7 \mathrm{~cm}$.

7. Sample 328B-2-1, $144-146 \mathrm{~cm}$.

Figures 8-10 Distephanus speculum pentagonus (Lemmermann).

8. Sample 328B-1-3, 5-7 cm.

9. Sample 328-2-4, 5-7 cm.

10. Sample $329-26-1,80-82 \mathrm{~cm}$. 
PLATE 6
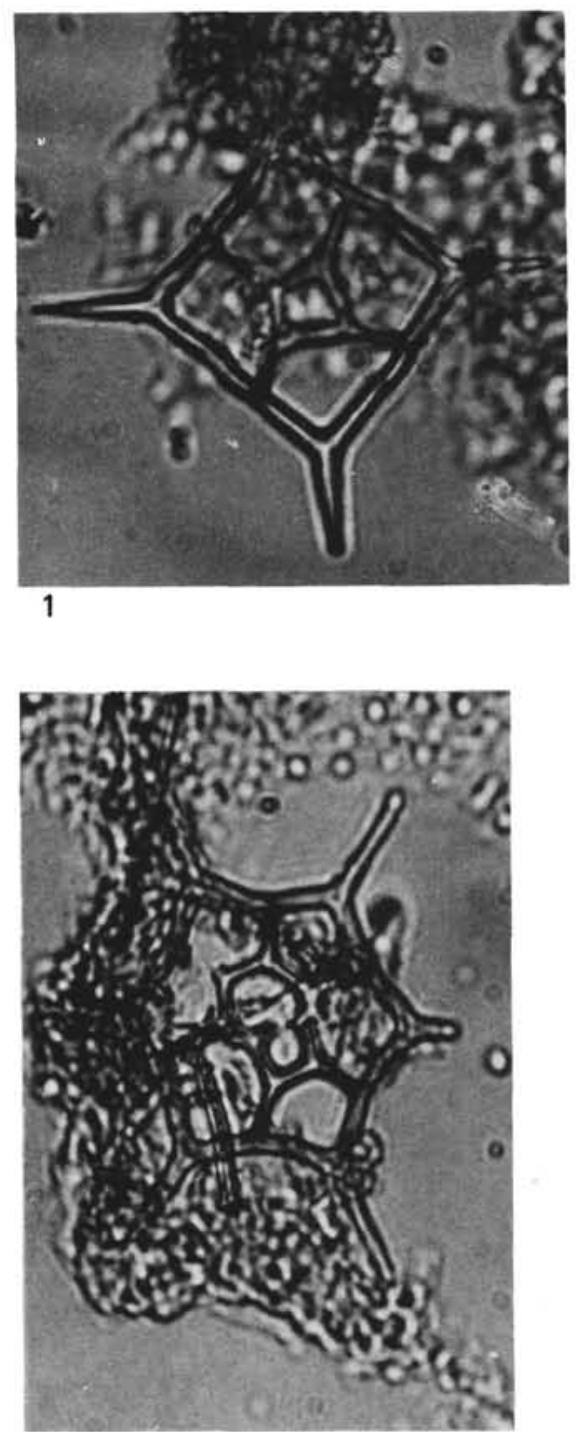

4

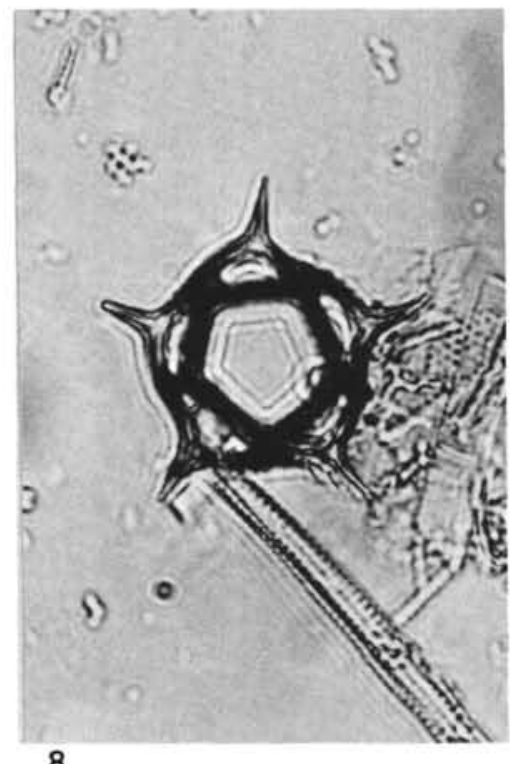

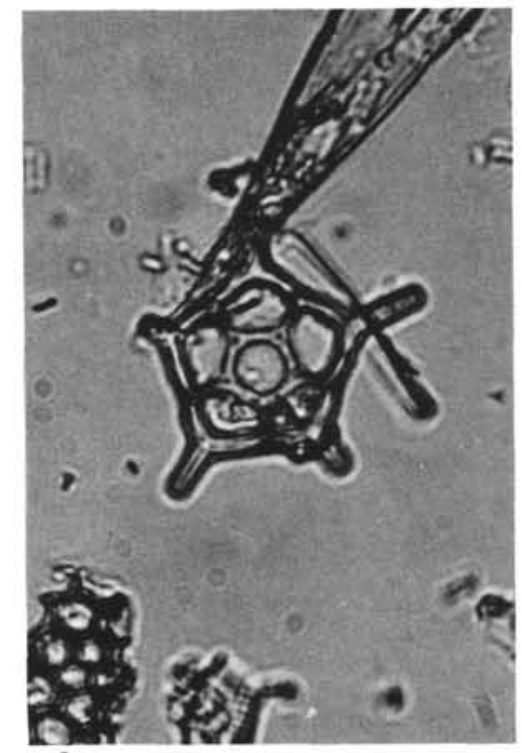

9
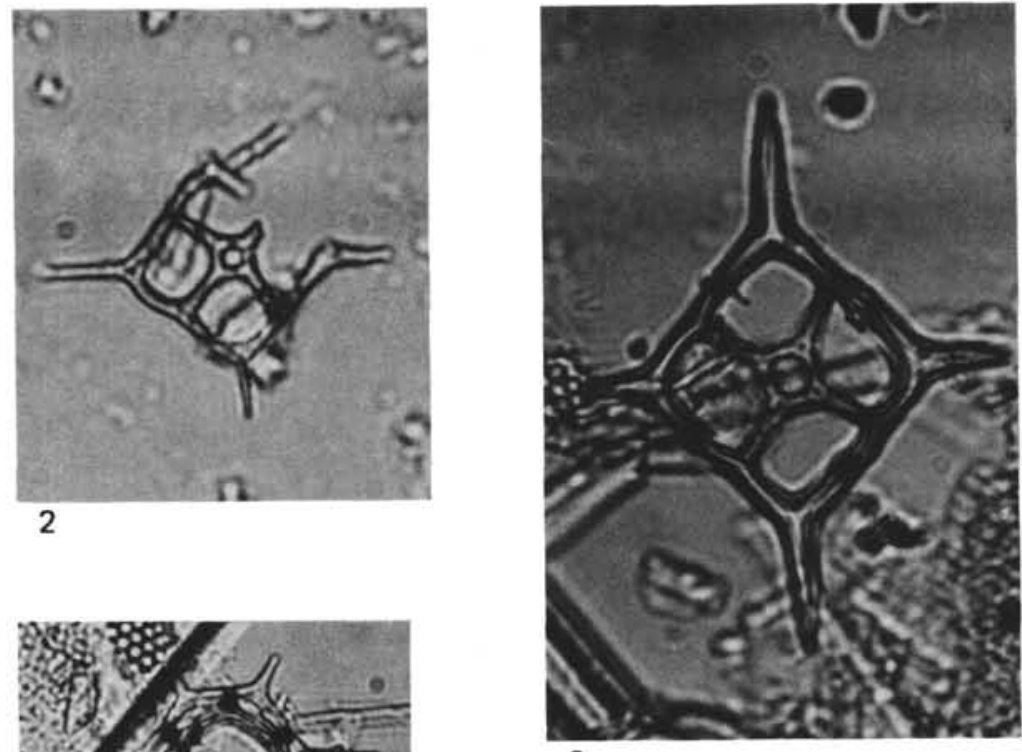

3
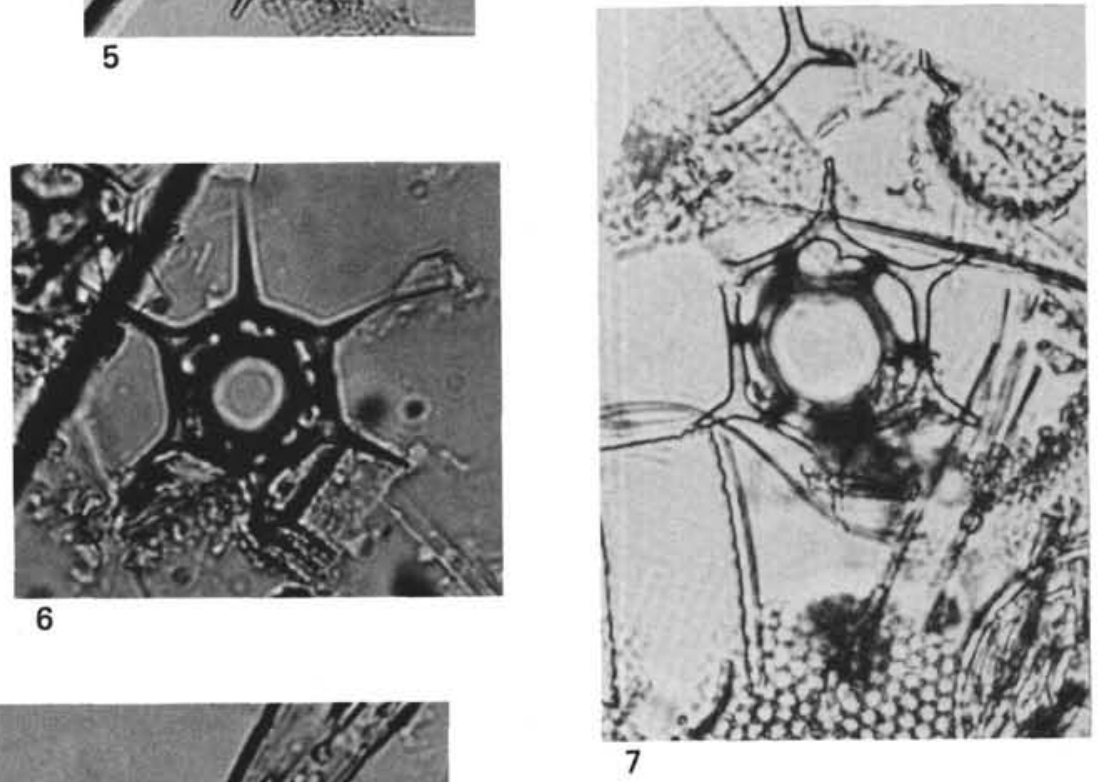

6

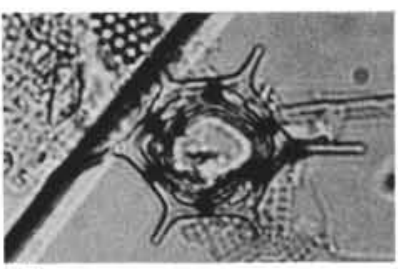

5

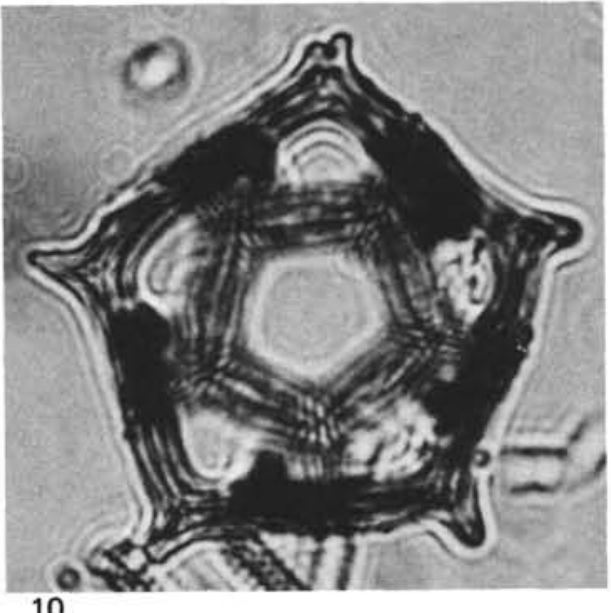


K. E. BUSEN, S. W. WISE, JR.

\section{PLATE 7}

(All specimens $3400 \times$ except Figure 6 which is $2800 \times$ )

Figures 1,5 Mesocena apiculata (Schulz).

1. Sample 329-29-1, $45-47 \mathrm{~cm}$.

2. Sample 328B-4-5, 3-5 cm.

Figures 2-4, 6 Mesocena circulus Ehrenberg.

2. Sample 329-12-1, 30-32 cm.

3. Sample 329-12-1, 30-32 cm.

4. Sample 329-12-1, 30-32 cm.

6. Sample 328B-2-1, 144-146 cm.

Figure 7 Mesocena diodon Ehrenberg, Sample 329-9-3, 114$118 \mathrm{~cm}$. 
PLATE 7
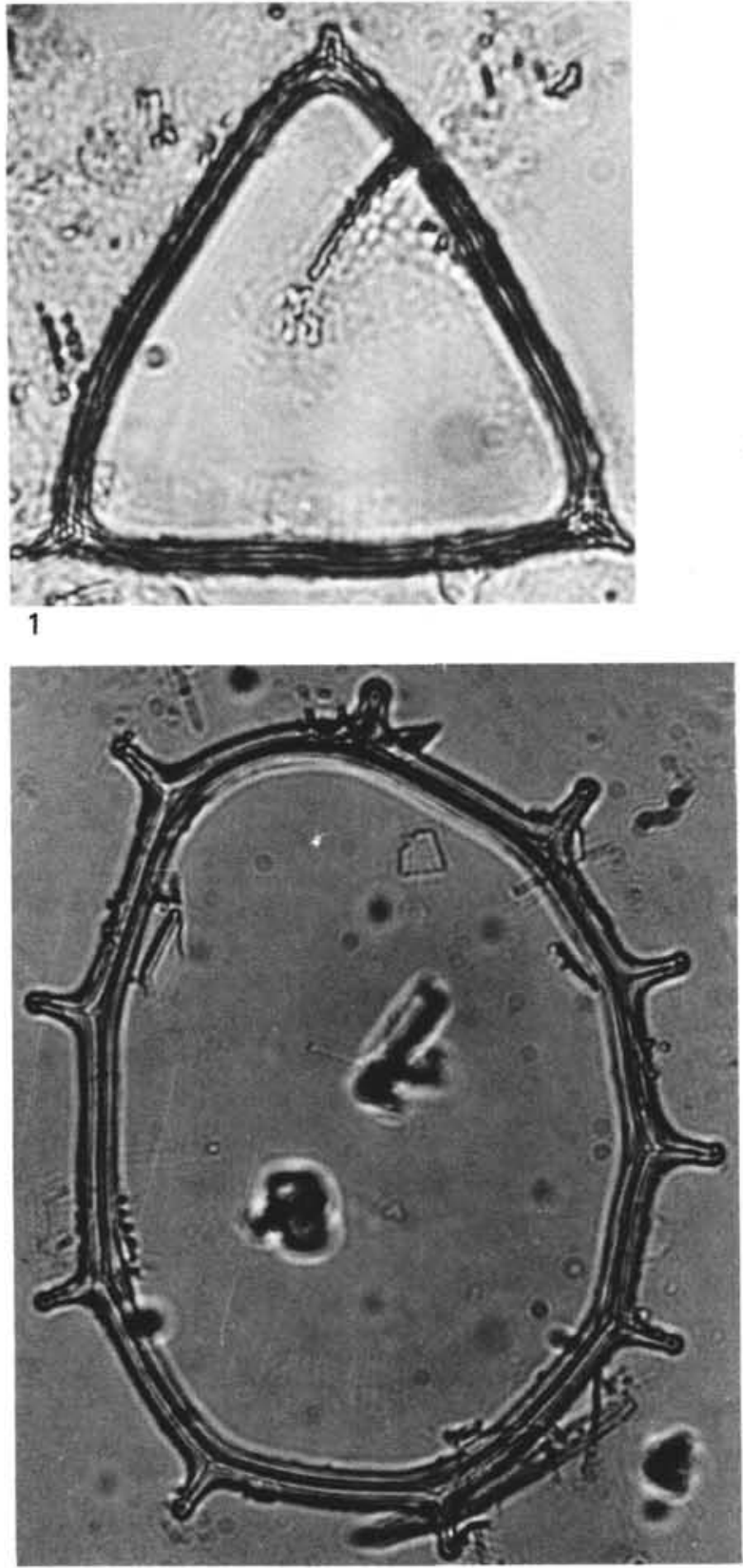

3

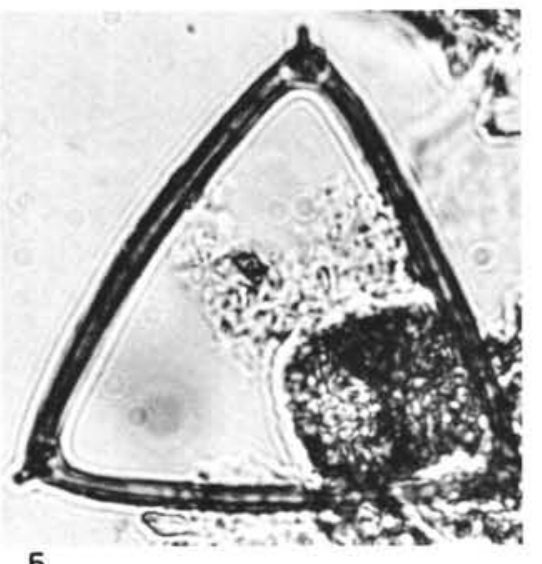

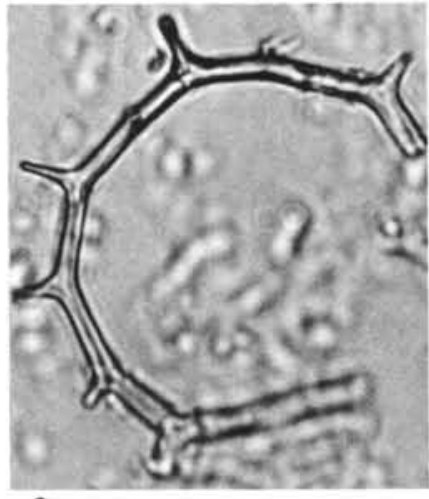

6
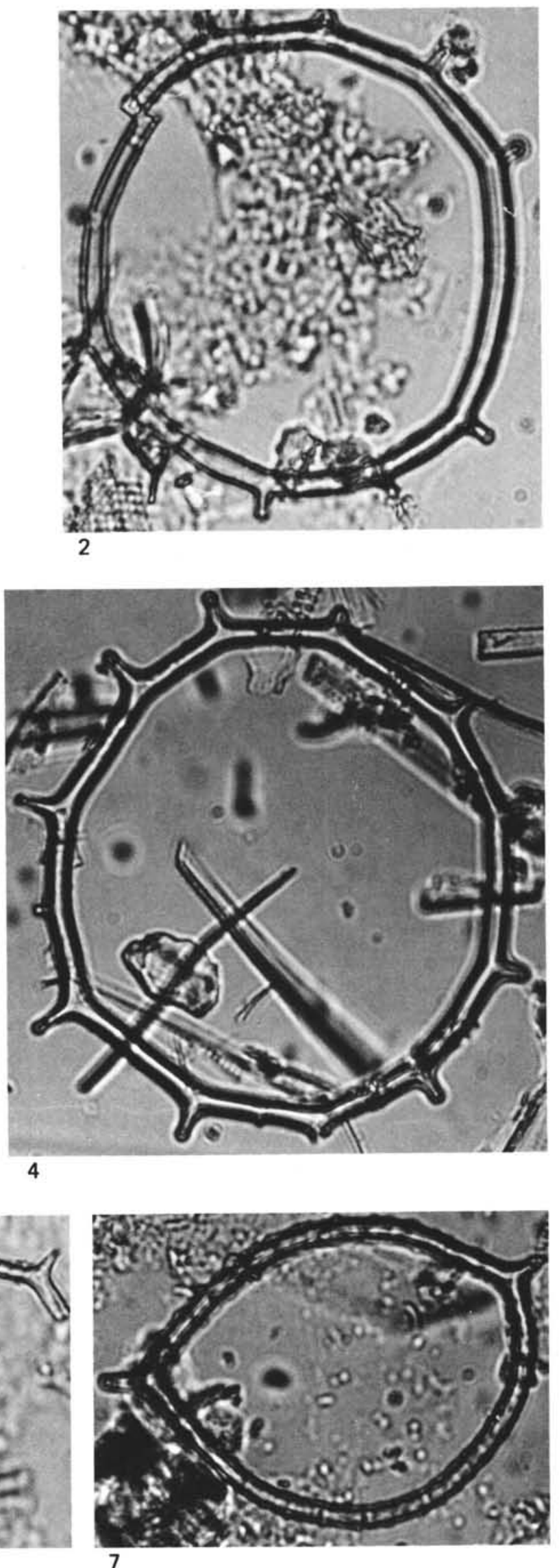


\section{PLATE 8}

(All specimens $3400 \times$ )

Figures 1, 3, 5 Mesocena diodon Ehrenberg.

1. Sample 329-9-3, 114-118 cm.

3. Sample $329-9-3,114-118 \mathrm{~cm}$.

5. Sample 329-9-3, 114-118 cm.

Figures 2, $6 \quad$ Mesocena oamaruensis Schulz.

2. Sample 328B-4-5, $3-5 \mathrm{~cm}$.

6. Sample 328B-4-5, 146-149 cm.

Figures 4, 7, 8 Mesocena occidentalis Hanna.

4. Sample 328B-4-5, 3-5 cm.

7. Sample 328B-4-5, 3-5 cm.

8. Sample 328B-4-5, 3-5 cm. 
PLATE 8
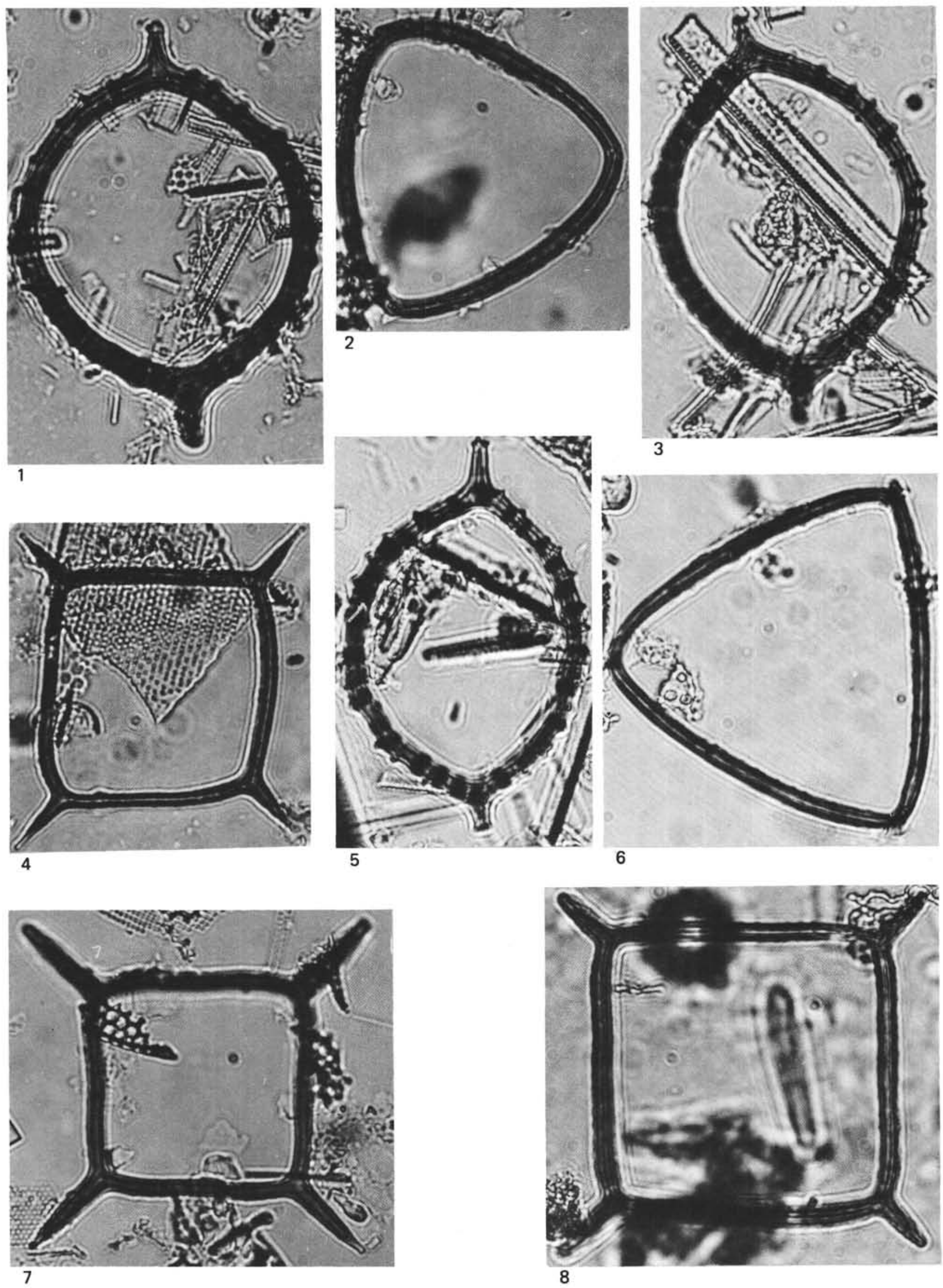


\section{PLATE 9}

(All specimens $3400 \times$ )

Figure 1 Naviculopsis biapiculata (Lemmermann), Sample 329-29-1, 45-47 cm.

Figures 2, $3 \quad$ Naviculopsis constricta (Schulz).

2. Sample 327 A-7-2, $45-47 \mathrm{~cm}$.

3. Sample $327 \mathrm{~A}-5-1,45-48 \mathrm{~cm}$.

Figures 4-6 Naviculopsis robusta Deflandre.

4. Sample 328B-4-5, 3-5 cm.

5. Sample 328B-4-5, $3-5 \mathrm{~cm}$.

6. Sample 328B-4-5, 3-5 cm.

Figures 7, $8 \quad$ Naviculopsis trispinosa (Schulz).

7. Sample $329-29-1,45-47 \mathrm{~cm}$.

8. Sample 328B-4-5, 3-5 cm. 
PLATE 9
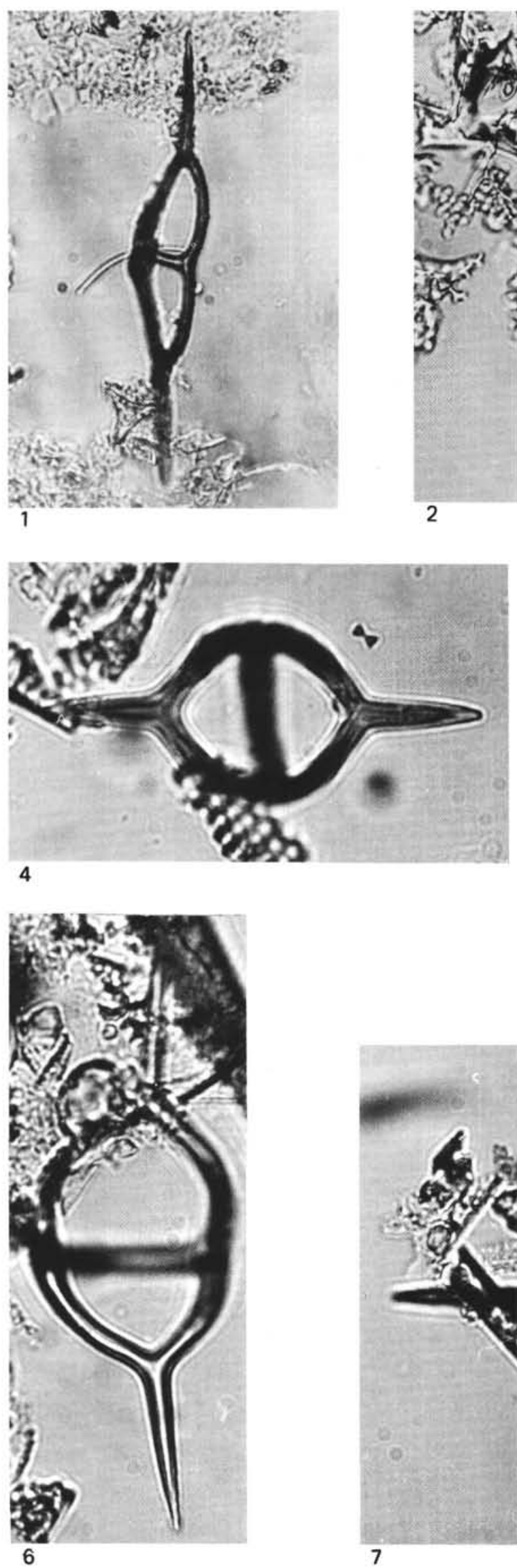
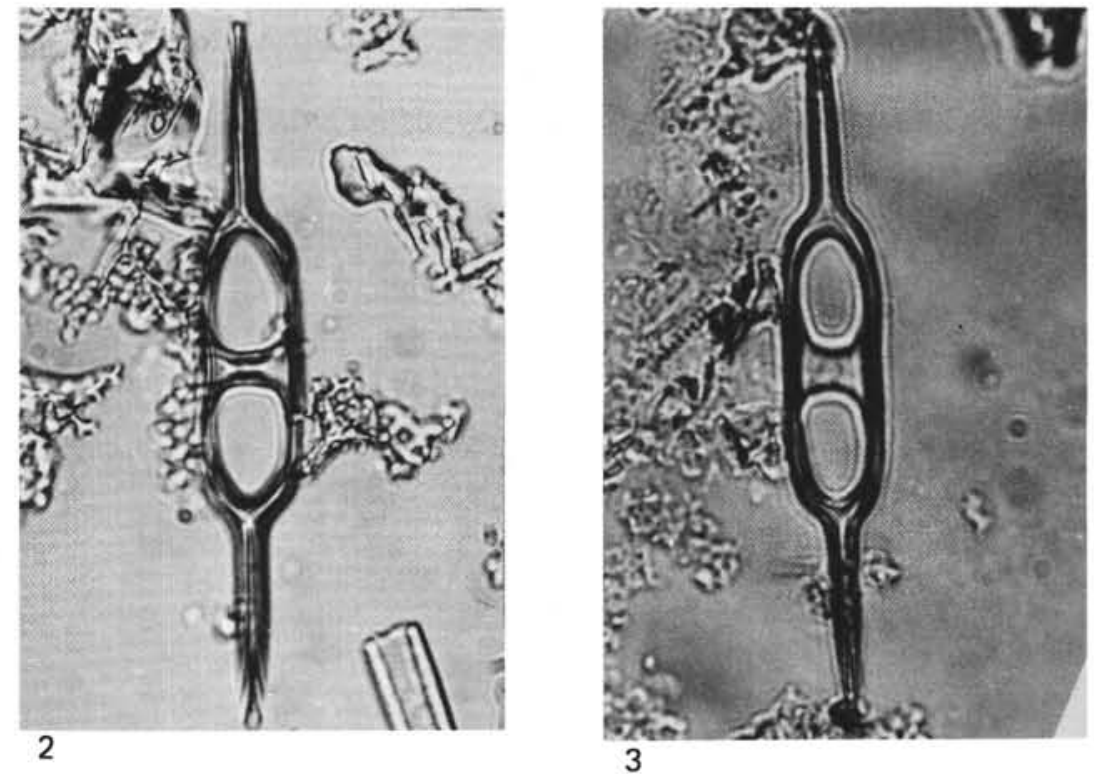
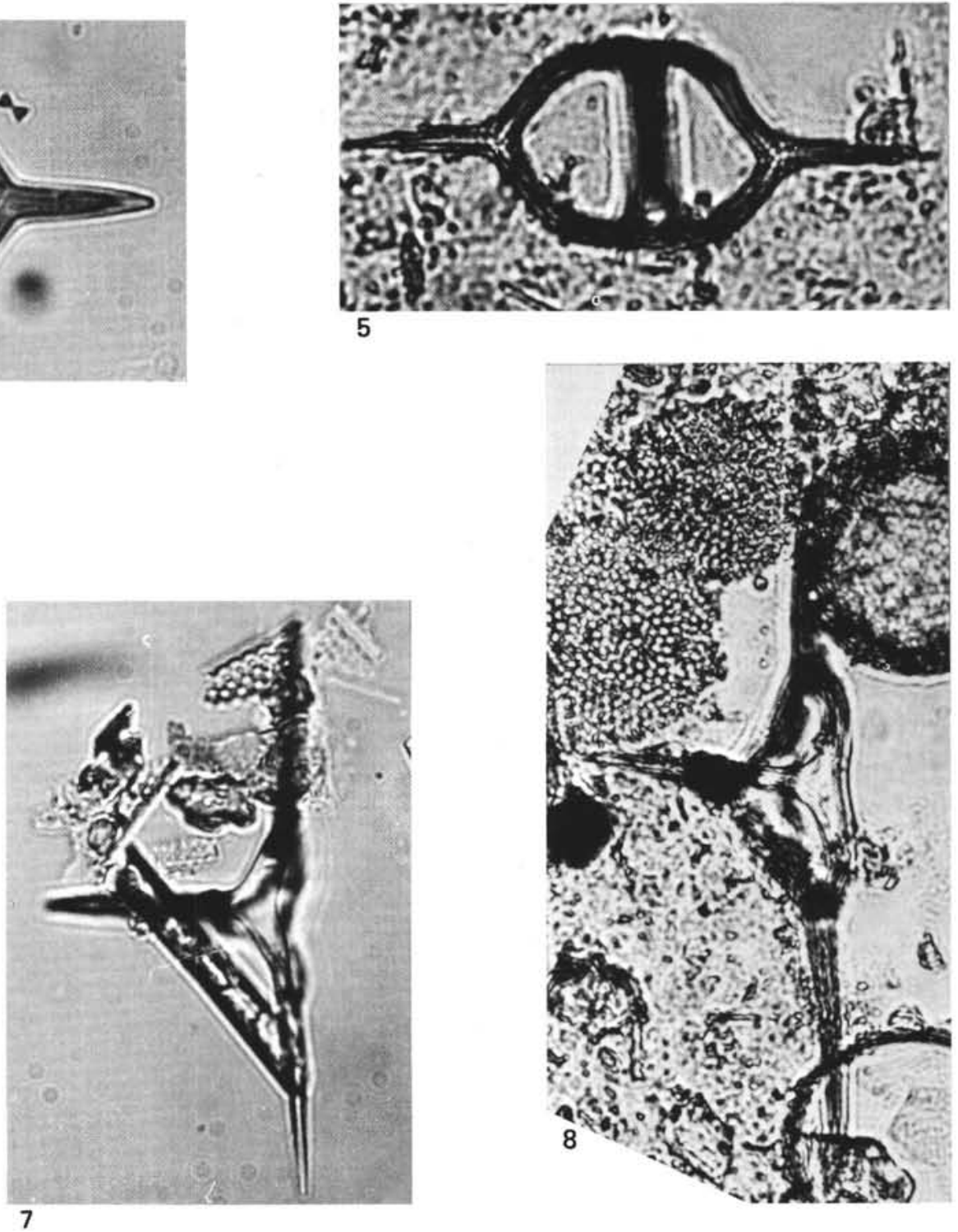
PLATE 10

(Scanning electron micrographs)

Figures 1, 4 Corbisema hastata Lemmermann.

1. Sample 327A-5-2, $82 \mathrm{~cm}, 3100 \times$.

4. Sample $327 \mathrm{~A}-5-2,83 \mathrm{~cm}, 3700 \times$.

Figure 2 Distephanus speculum speculum (Ehrenberg), Sample $329-1-1,120-122 \mathrm{~cm}, 1600 \times$.

Figure 3 Distephanus speculum pentagonus (Lemmermann), Sample $329-1-1,120-122 \mathrm{~cm}, 2000 \times$. 
PLATE 10
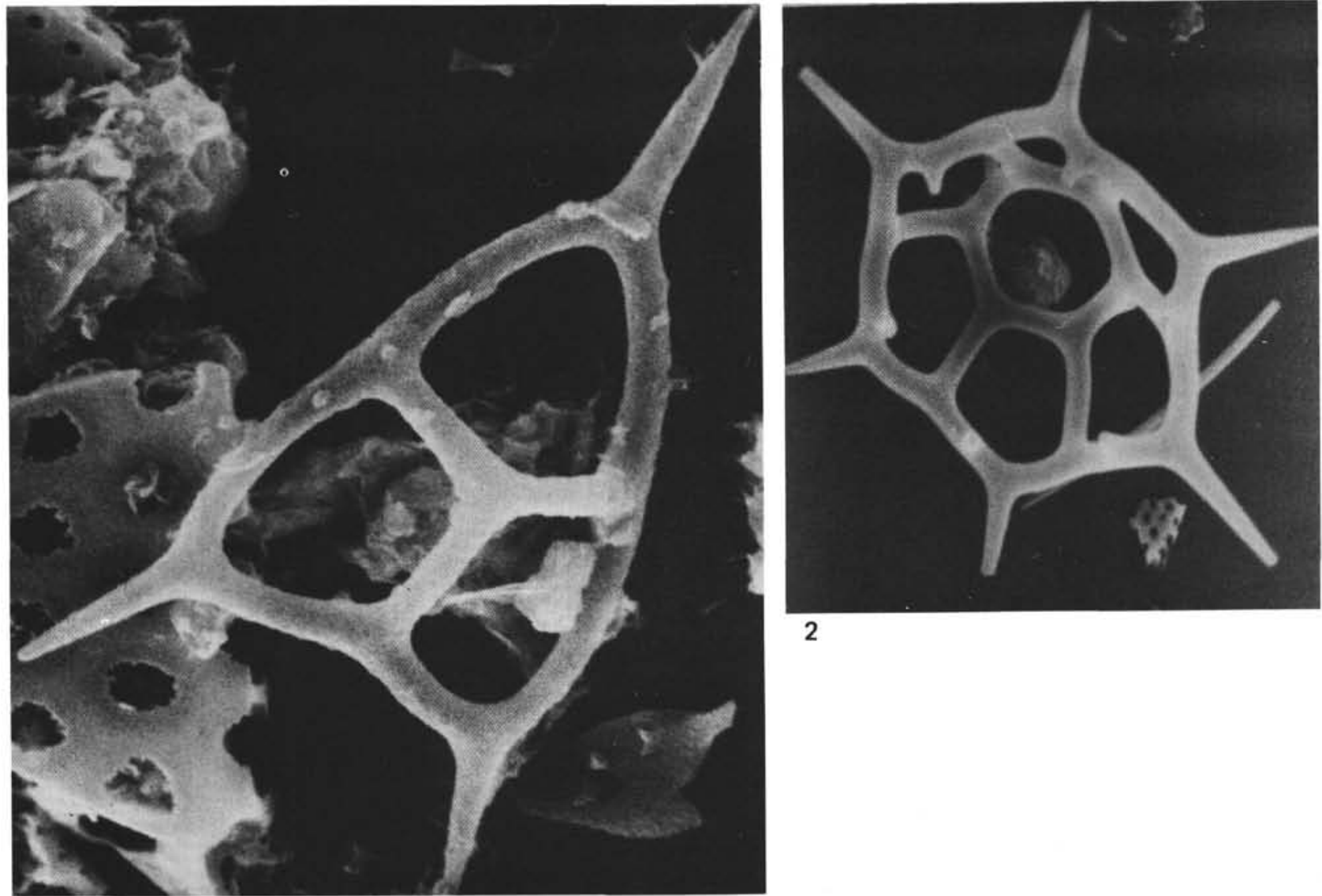

2

1
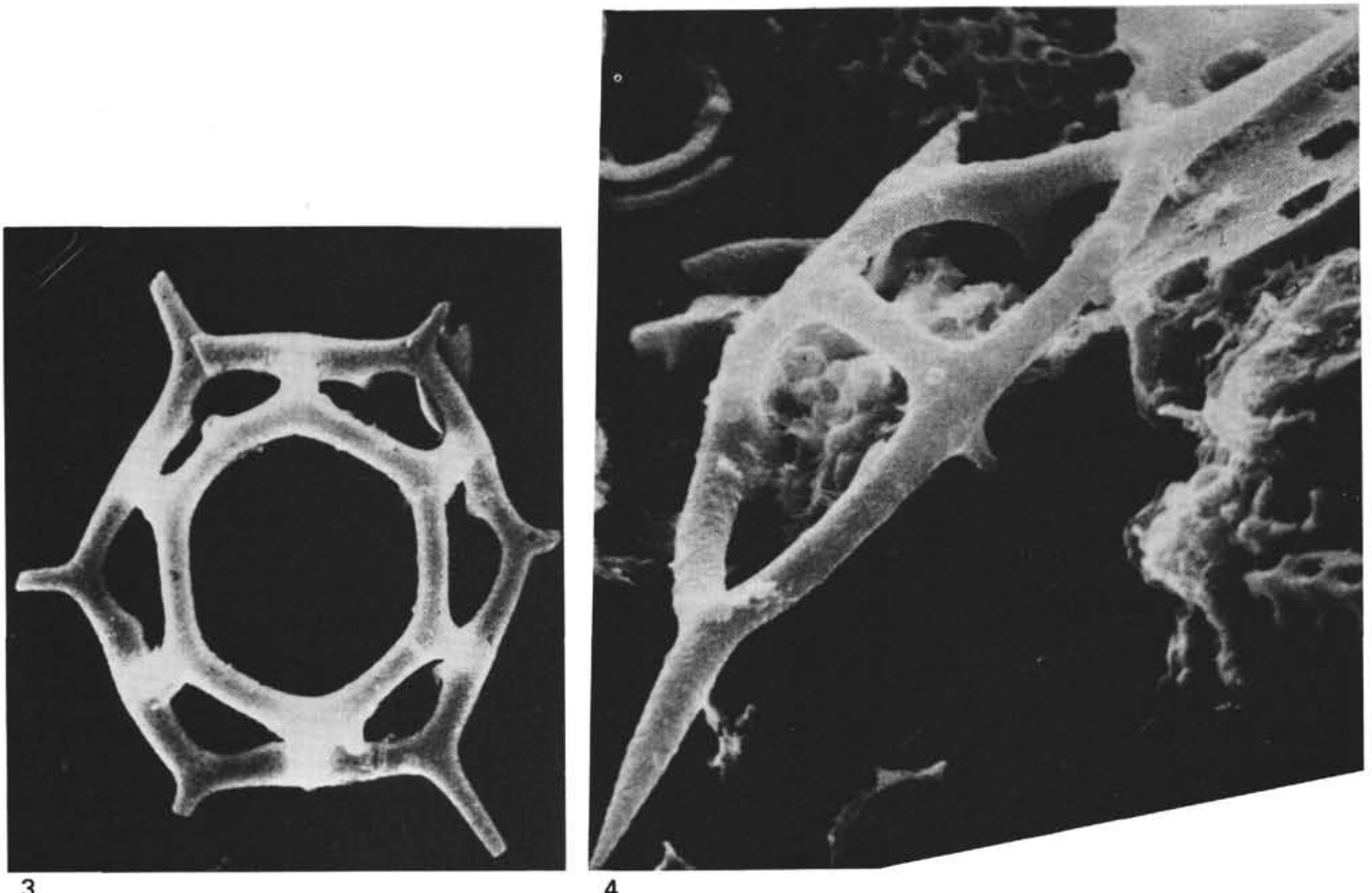
PLATE 11

(Scanning electron micrographs)

Figures 1,2 Mesocena circulus Ehrenberg.

1. Sample $329-7-5,120 \mathrm{~cm}, 2300 \times$.

2. Sample $329-7-5,120 \mathrm{~cm}, 2300 \times$.

Figures 3, $4 \quad$ Naviculopsis constricta (Schulz).

3. Sample 327A-5-1, $3 \mathrm{~cm}, 4400 \times$.

4. Sample 327A-5-1, $3 \mathrm{~cm}, 3900 \times$. 


\section{PLATE 11}
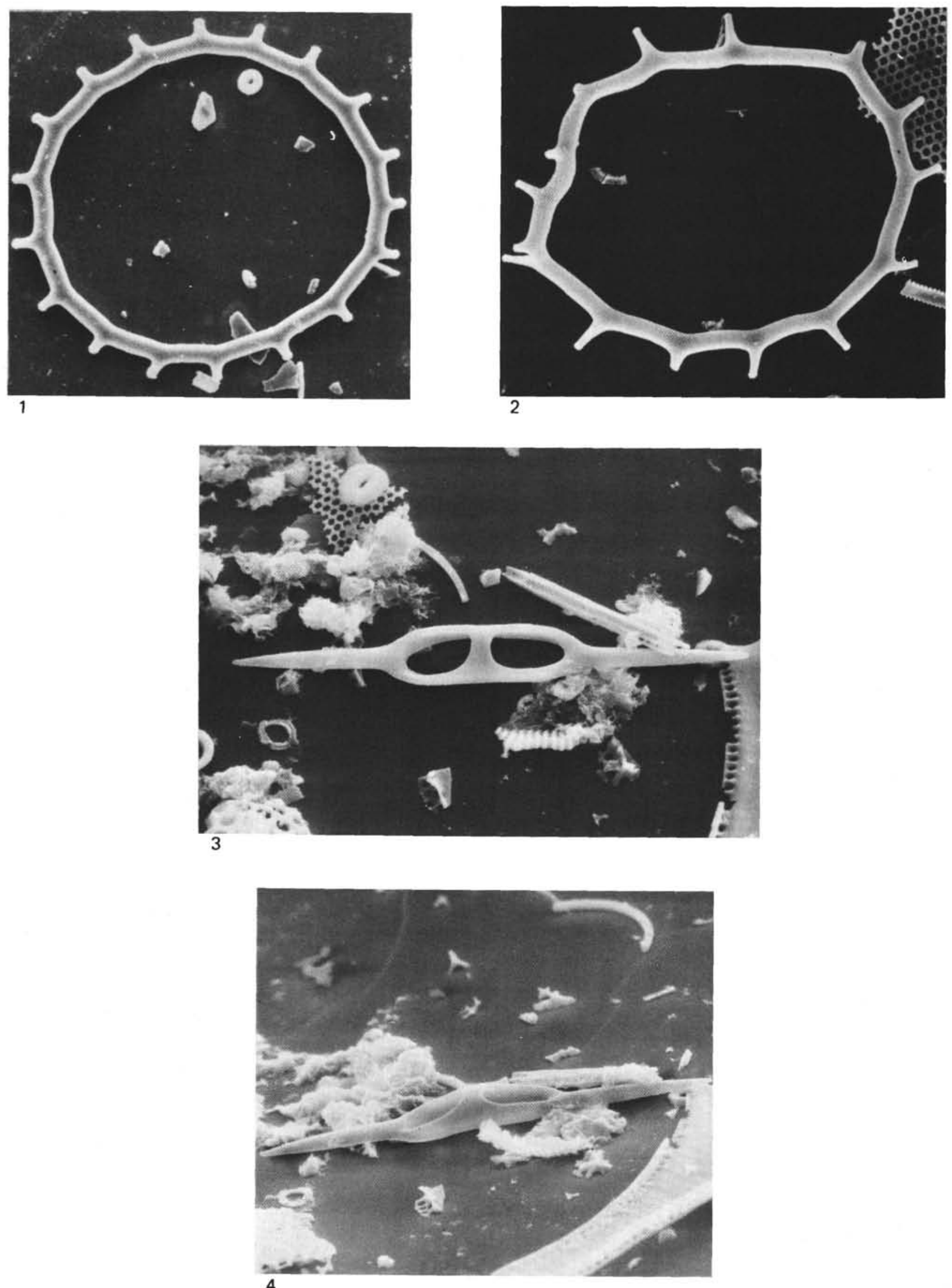


\section{PLATE 12}

(All figures $3400 \times$ except Figures 3, 4, and 5 which are $3000 \times$ )

Figures 1-6 Pseudomicromarsupium gombosum, n. sp. 1. Paratype USNM 241307, Sample 327A-7-1, $140-142 \mathrm{~cm}$.

2. Paratype USNM 241308, triangular plate missing, sample $327 \mathrm{~A}-5-6,2-4 \mathrm{~cm}$.

3. Holotype USNM 241309, phase contrast, medium focus, Sample 327A-6-1, $102 \mathrm{~cm}$.

4. Same specimen, high focus.

5. Same specimen, phase contrast, high focus.

6. Paratype USNM 241310, side view, RC-15-84, $525-527 \mathrm{~cm}$. 
PLATE 12
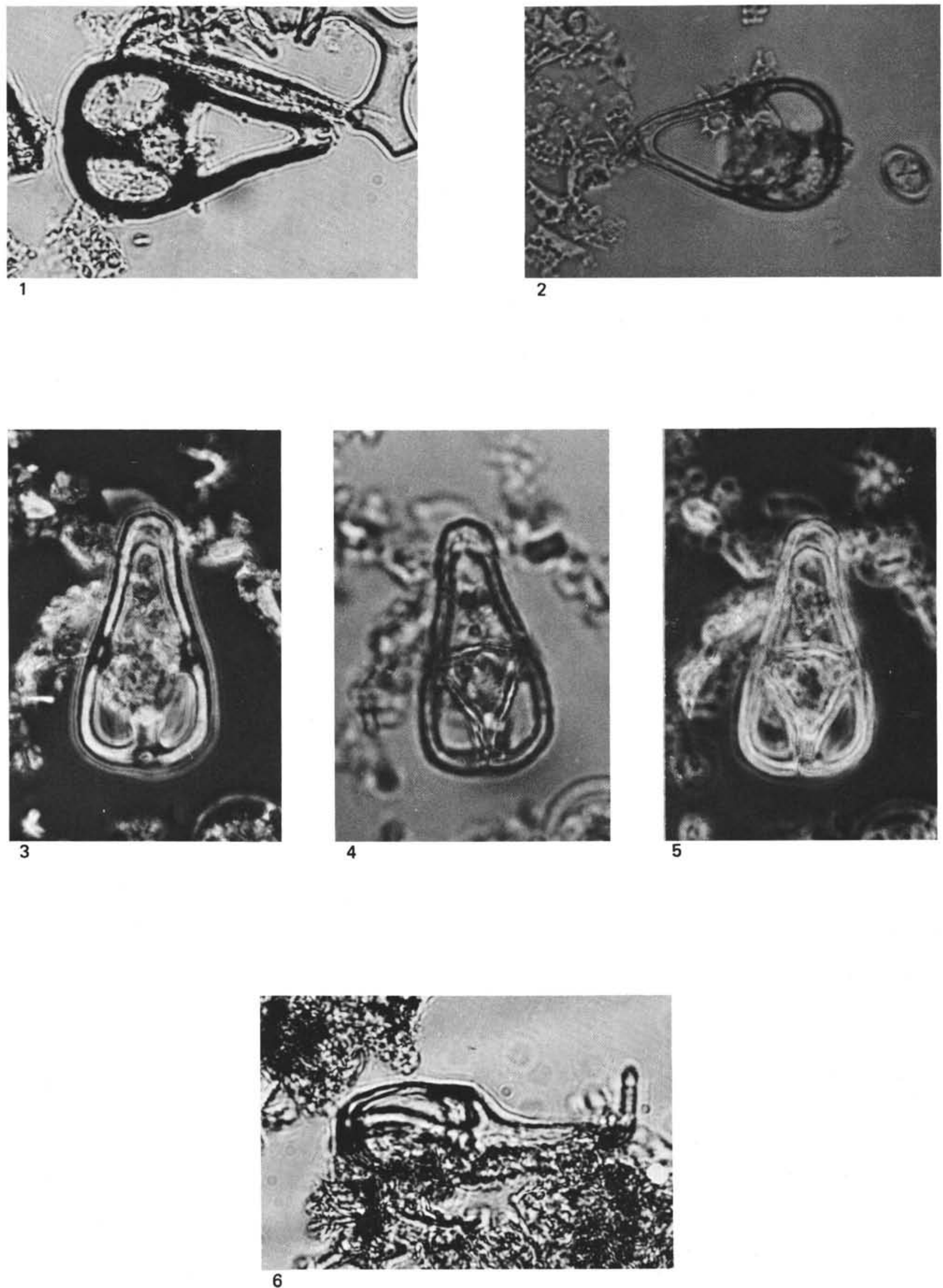